\title{
Performing Placeslessness: Early American Drama and the Liminal State, 1775-1859
}

James R. Holsinger

Follow this and additional works at: https://researchrepository.wvu.edu/etd

\section{Recommended Citation}

Holsinger, James R., "Performing Placeslessness: Early American Drama and the Liminal State, 1775-1859" (2015). Graduate Theses, Dissertations, and Problem Reports. 5816.

https://researchrepository.wvu.edu/etd/5816

This Dissertation is protected by copyright and/or related rights. It has been brought to you by the The Research Repository @ WVU with permission from the rights-holder(s). You are free to use this Dissertation in any way that is permitted by the copyright and related rights legislation that applies to your use. For other uses you must obtain permission from the rights-holder(s) directly, unless additional rights are indicated by a Creative Commons license in the record and/ or on the work itself. This Dissertation has been accepted for inclusion in WVU Graduate Theses, Dissertations, and Problem Reports collection by an authorized administrator of The Research Repository @ WVU.

For more information, please contact researchrepository@mail.wvu.edu. 
Performing Placeslessness: Early American Drama and the Liminal State, 1775-1859

\author{
James R. Holsinger
}

Dissertation submitted to the Eberly College of Arts and Sciences at West Virginia University in partial fulfillment of the requirements for the degree of

Doctor of Philosophy in

English

Timothy Sweet, Ph.D., Chair

Cari Carpenter, Ph.D.

Ryan Claycomb, Ph.D.

Peter Reed, Ph.D.

Kathleen Ryan, Ph.D.

Department of English

Morgantown, West Virginia

2015

Keywords: Early American Drama, Performance, Theories of Space and Place, Antebellum Drama

Copyright 2015 James R. Holsinger 


\section{ABSTRACT \\ Performing Placelessness: Early American Drama and the Liminal State, 1775-1859}

\section{James R. Holsinger}

In Performing Placeslessness, I argue that the lack of a consistent attachment to place- the geopathology that manifests in the problem of placelessness - contributed to the incoherence of American identity from the Revolutionary War through the mid-nineteenth century. In making this argument, I bridge the critical gap between Martin Brueckner's description of the geographic revolution (late-seventeenth to mid-eighteenth century) and Una Chaudhuri's Staging Place, in which she characterizes place as a problem in modern realist drama. Examining dramatic publications and performances from 1775-1859, I treat drama as a key site of negotiating problematic conceptions of space and place in America. This period was characterized by a number of spatial disruptions: political geographies were redrawn, frontiers were no sooner defined than pushed further west, and colonial outposts became populous cities through the process of urbanization. Place was paramount on the early American stage both because the theatre reflected the displacement at the heart of early American life (and thus achieved a level of anxiety-provoking mimesis) and because the stage was inherently dislocated in its phenomenology. While all theatre takes us "somewhere else," the early American theatre was distinctive in its capacity to comprise both a mimetic and phenomenological placelessness.

Displacement wasn't merely an obstacle to the formation of a sense of nation (though this was indeed the case). The displacement experienced by early Americans was at once a central and disavowed component of identity formation. The same early Americans who experienced their own anxieties of placelessness came to define themselves in opposition to displaced others. Native Americans were pushed further from the eastern seaboard, and slaves, by their very presence in the nation, contradicted the symbol-making process described by Brueckner. That is, for whites to locate their place of entitlement in the colonies, they needed to disenfranchise those enslaved blacks and Native Americans who could be found within colonial borders. We see the erasure of those who didn't "count" within the nation most clearly in the dramatic performances of George Aiken's Uncle Tom's Cabin (1852) and Dion Boucicault's The Octoroon (1859), as these plays resituated the South, its slaves, and lingering Native Americans as foreign to Northern theatregoers. Thus non-white bodies were effectively disenfranchised and displaced, both literally and figuratively, during stage performances that many associated with the fight for abolition. At the same time, I argue that the dramatic mode enabled the comparatively marginalized - women playwrights like Mercy Otis Warren and Charlottes Barnes, or a mixedrace former slave like William Wells Brown - to re-orient and resist their own displacement through the spatial orientations of drama. 


\section{Table of Contents}

Introduction:

Performing Placelessness: Early American Drama and the Liminal State, 1775-1859

Chapter One:

Resituating Public and Private Space: The Political Drama of Mercy Otis Warren

Chapter Two:

Pocahontas Plays, Melodrama, and the Displacement of History Onstage

Chapter Three:

Misplaced Sympathy: Depicting Slaves in "Foreign" Lands

Chapter Four:

The One-Man Show as Counter-Performance: William Wells Brown's The Escape and the Segregation of Dramatic Space

Epilogue:

All Theatre is Environmental, All Performance is Site-Specific

Works Cited: 


\section{Introduction: Performing Placelessness: Early American Drama and the Liminal State, 1775-1859}

When William Hallam set out to bring the first professional theatre company to America's shores in 1754, he did so after failing to find the success—and wealth—he sought in London. ${ }^{1}$ The American colonies held the promise of a new start and, as for so many others who voyaged to this "new world," the possibility of financial gain. The enlisted actors who agreed to make the dangerous voyage met at Hallam's home to discuss their plans, where they gathered costumes and scenery so as to begin productions immediately upon arrival. According to William Dunlap, successful playwright, producer, and the first historian of the early American stage, once assembled, Hallam introduced the plays that would be produced, assigned parts "both private and public, behind and before the curtain," and appointed Lewis, William's brother, as “manager, chief magistrate or king" and William as 'Viceroy over him”" (qtd. in Hornblow 73). ${ }^{2}$ This description is telling in its reliance on a metaphor of colonization. William Hallam organizes his troupe by mimicking the colonial system already in place in America: players become colonists, performing under the tutelage of Lewis, who ultimately acts in the best financial interests of his brother, half a world away.

Before Hallam's company could become the first professional performance group in North America, though, the troupe had to weather a long and perilous passage across the Atlantic. Given the troupe's desire to start performing — and making money—upon their arrival, the company made the most of their lengthy voyage. Dunlap describes the troupe's time at sea with the characteristic flair of a man well-versed in the dramatic arts:

The foresight exercised by the Hallams in preparing their company for immediate action on their arrival in America, merits applause. The pieces had been selected, cast, and put 
in study before embarkation; and during the passage they were regularly rehearsed. The quarter-deck of the Charming Sally was the stage, and whenever the winds and weather permitted, the heroes and heroines of the sock and buskin performed their allotted parts, rehearsing all the plays that had been selected, particularly those fixed upon to form the first theatrical exhibition which was to enliven the wilds of America. (11)

Dunlap's comparison of the stage on the Charming Sally to the wilderness that awaits these performers is telling in its insistence on America as tabula rasa, awaiting inscription by British hands. Taken together, Hallam's traveling-troupe-as-colonial-project metaphor and Dunlap's description of the birth of professional performance in America share an interest in American genesis, as origin stories not of Euro-Americans (like John Smith's Generall Historie) but of professional players in the new world.

Dunlap's description, with its thematic of placelessness, gestures towards the interrelation of place, stage, and nation from the American stage's conceptual beginning. Beneath the rhetorical bluster, behind the "heroes and heroines of the sock and buskin," and at the heart of Dunlap's mythology of the American theatre's origins, we find in this performance at sea a microcosm of theatre culture that persisted in early America, where performances took place in cities and towns that were, like the Charming Sally, inhabited by a people unmoored, set adrift. In urban centers rural patrons must have felt a sense of dislocation as they were often meant to see themselves in characters that were similarly displaced. During and after the Revolution, American soldiers were displaced from their homes, while British soldiers staged dramatic performances on colonial soil, a useful distraction when in an unfamiliar land, far from home. For others, the dislocation and displacement of everyday life resisted representation altogether. Native Americans were repeatedly displaced as the "frontier" shifted west, and, as property, 
slaves experienced a "geographic confinement" that led to "a despatialized sense of place" (McKittrick, Demonic, 9). Colonists, Native Americans, and slaves certainly had very different experiences in the early national period, but they all faced a degree of displacement that complicated the formation of a coherent national identity.

Indeed, even the label "early national" implies a level of geographic and political cohesion that misrepresents "the first modern nation deliberately fabricated de novo," with its far-clung colonies, shifting geopolitical boundaries, and uncertain national economy (Looby 3). It makes a great deal more sense to consider this period, as Gordon Wood does, as an "experiment in Republicanism," a phrase that speaks to the very real possibility that the nation might at any moment collapse on its newly constructed foundations (5). Lawrence Buell writes that we "cannot theorize scrupulously about place without confronting its fragility," and nowhere is this more apparent than in the political and cultural fragility that early Americans experienced during the transition from British colonies to independent nation (Future 62). The closer one looks at the early days of this experiment, the more disjointed, disconnected, and displaced the colonists seem.

Much work has been done to link the political unrest of the revolution to linguistic instability, with the primary evidence of the latter coming in the form of a burgeoning print culture that inundated the market with texts meant to pin down a common language. Noah Webster's dictionary, for instance, went through 221 editions and 10 million copies from 1800 to 1840, sales that dwarfed a popular novel like Cooper's The Spy (1821), which went through only seven editions (Shweiger 541-2). This may only convey part of the story, though, as Jay Fliegelman's Declaring Independence, Christopher Looby's Voicing America, and Sandra Gustafson's Eloquence is Power offer a necessary supplement to the early American interest in 
developing shared, consistent language practices. Their collective works revise the misconception that "constitutional authority was intimately dependent upon the textuality of that instrument" noting instead the "widespread cultural investment of authority in vocal forms like oration and sermons" (Fliegelman 2; Looby 44). Gustafson, in particular, calls into question the artificial unhinging of oral and print forms, as she claims that "the full significance of linguistic form for civic self-understanding in the United States emerges only through studying relationships between speech and writing" (267). This conversation responds most notably to the earlier work of Michael Warner, who, in Letters of the Republic connects the creation of a public sphere to the proliferation of print in eighteenth-century colonial America. In Fliegelman's estimation, Warner's work privileges print while ignoring the "dialectical relation between the authority of impersonality rooted in the discourse of descriptive science and the authority of sincerity rooted in the discourse of affective experience" (129). The critical move away from logocentrism has resulted in a more holistic view of how meaning was made in early America, one that takes note of not just texts, but also embodied speech.

It seems prudent, then, that we turn our attention to the spatial disruption that occurred alongside linguistic and political shifts that dominate the critical discourse above. Indeed, there is ample evidence that geographic changes fed the anxieties of the British colonists. As Martin Brueckner argues, from the late-seventeenth to the mid eighteenth-century, British Americans produced a "culture of geographic letters" through surveys, property maps, and geography textbooks, in an effort "to quite literally get their feet on the ground, granting them a sense of place and entitlement, engendering a process that led to the Revolution" (14). These geographic texts served an important purpose for British colonists. "It is characteristic of the symbol-making human species," writes Brueckner, "that its members can become passionately attached to places 
of enormous size, such as a nation-state, of which they can have only limited direct experience" (18). This would have been quite a challenge for British colonists who fell under the political rule of a nation an ocean away, and whose experiences were confined to a very local level. Brueckner's argument begs the question: how did these efforts proceed, and to what degree were British colonists successful in acquiring a "sense of place and entitlement"?

Comparing the size of North America with Great Britain on a map may have helped "colonial speakers and authors...turn this knowledge to their forensic advantage," but these same maps would have been largely anachronistic as national surveys increased the production of cartographic representation exponentially by the end of the eighteenth century (Brueckner 91, 121). Colonists certainly used these maps to form place attachments, but every cartographic revision would have required this symbolic process to begin anew. While the increase in colonial maps helped early Americans conceive of themselves in relation to their political and geographic reality, "there was a wide gap between cartographical affirmation and what was actually happening on the ground," where borders were contested and cartographies were revised in real time (Elliot 35).

An integral part of this process of place attachment through geographic symbols was the erasure of those who didn't "count." Unlike the British colonists, Native Americans were pushed further from the eastern seaboard, and slaves, by their very presence, contradicted the symbolmaking process described by Brueckner. That is, for whites to locate their place of entitlement in the colonies, they needed to disenfranchise those enslaved blacks and Native Americans who could be found within colonial borders. Nor was this process completed in the ensuing decades. At issue in Cherokee Nation v. the State of Georgia (1831) was the political and geographic uncertainty that resulted from the presence of Native Americans who came to constitute a "hole 
in the map within the perimeters of Georgia" (Wald 26). In short, to find a "sense of place and entitlement" in the glut of geographic publications before the revolution required the disenfranchisement of Native Americans and slaves, a process that would continue long after America gained its independence.

Despite the constant geographical imaginings inherent to early American culture, scholars like Una Chaudhuri suggest that place remains a problem in our own culture. In Staging Place: The Geography of Modern Drama, she defines "geopathology," as "the characterization of place as a problem," which she pinpoints as a key feature of modern drama (xii). For Chaudhuri, "the figure of America first signified a kind of ultimate placelessness, a guarantee of the absolute unmeaning of place as a component of human experience" (5). It is in this definition that we can connect the geographic revolution to Chaudhuri's work: the failure of the geographic revolution helps to describe the impetus for the modern geopathic state in which Americans haven't yet solved the problem of place. Given what we know about the geographic revolution of the seventeenth and eighteenth centuries and the geopathology that persists in modern America, it seems reasonable to conclude that place remained a problem in the interim between these points of reference. This dissertation contends that dramatic texts and embodied performances from the early national period reveal these anxieties in their spatial orientations, offering us the best means of recovering the problem of placelessness.

My understanding of place (and its absence) stems primarily from the field of ecocriticism. In Space and Place: Theories of Identity and Location, Erica Carter, James Donald, and Judith Squires differentiate between place, which they define as "space to which meaning has been ascribed" and space, to which no additional meaning is assigned (xii). Lawrence Buell expands on this definition, as he argues that any space can become a place: a place "can be as 
small as a sofa...or as big as a planet: earth longingly seen by astronauts from the moon" (Writing 59-60). Yet place is also elusive by its nature since it has "by definition both an objective and a subjective face, pointing outward toward the tangible world and inward to the perceptions one brings to it" (Buell, Writing, 59).

In the chapters that follow, I study dramatic texts and performances in an effort to bridge the gap between the geographic revolution and the geopathology of modern drama. Examining publications and performances from 1775-1859, I treat drama as a key site of negotiating problematic conceptions of space and place in America. As I will show, early American attempts at dramatic symbol-making were frustrated by a residual placelessness that carried over from the colonial era to post-Revolutionary America and into the antebellum period. This period was characterized by a number of spatial disruptions: political geographies were redrawn, frontiers were no sooner defined than pushed further west, and colonial outposts became populous cities through the process of urbanization. Where Brueckner charts the efforts of early Americans to gain a sense of place, my study locates the ways that early national drama struggled under the weight of its own geopathological burdens during and after the American Revolution.

I suggest that this lack of a coherent and consistent attachment to place- the geopathology that manifests in the problem of placelessness - contributed to the incoherence of American identity from the Revolution to the Civil War. By describing the national identity as incoherent, I mean to emphasize both the disjointed nature of the early nation as well as the inability of early Americans to recognize it as such. As a result, displacement wasn't merely an obstacle to the formation of a sense of nation (though this was indeed the case). It was at once a central and disavowed component of identity formation. The same early Americans who experienced their own anxieties of placelessness came to define themselves in opposition to 
displaced others, most notably slaves and Native Americans. Whites, for instance, consistently undermined a black sense of place through the "hegemonic spatial practices" inherent to slavery and by literally displacing Native Americans through forced relocation (McKittrick and Woods 7). Struggling to resolve or even see this paradox, early American writers displayed the symptoms of this geopathology in their work.

It should come as little surprise, then, that for early Americans, writing-like the maps created during the geographic revolution — aspired to cohere the nation-state, but more often reflected anxieties of placelesness and displacement. J. Hector St. John de Crevecoeur and Thomas Jefferson, for instance, appropriated agricultural spaces "for national purposes because of certain historical genealogies of thought—-promoted by John Locke and many other Enlightenment thinkers — which argued that investing physical labor in the earth transformed wild space into private property, thereby taming and subduing it" (Schell 586). A discourse of place also emerged in the early nineteenth century historical fiction of Washington Irving and James Fennimore Cooper. Irving's History of New York (1809) may assume "the task of rescuing the history of the Dutch settlement of New York," but in doing so it also works to recover a people displaced by history and historians (Insko 605). Cooper's Leatherstocking Tales chronicle the displacement of Native Americans by encroaching whites, and, through frontiersman Natty Bumppo, the interstices of white conquest and native resistance. In her study of national narratives, Priscilla Wald points out that "authorship — the process of writing — emerges consistently as a means of exploring the internalized frontiers that constituted them as Americans" (10-11). Yet this exploration is always troubled by the paradoxical nature of the frontier. Frontiers are, in the words of Michel de Certeau, "created by contacts, the points of differentiation between two bodies are also their common points" (127). To be placeless was to 
take the frontier with you wherever you went, and to live, like Natty Bumppo, in the void between space and place.

What particular role, though, did dramatic texts and theatrical performances play within this larger literary movement? Lacking any meaningful place attachment, early Americans often turned to the theatre, where they found not a space around which a national identity could cohere but rather a medium that by its very nature brought the foreign, the unknown, the distant closer. In some ways, this shouldn't be all that surprising. For instance, Bert States argues against the idea that theatre should be —or ever is — purely mimetic, for to entertain this notion is to privilege the semiotic over the phenomenological. This is not to say that mimesis is unachievable or absent in the theatre. In fact, States is careful to present mimesis (which he calls semiosis) and phenomenology as complementary rather than mutually exclusive modes of interpretation, as they "constitute a kind of binocular vision: one eye enables us to see the world phenomenally; the other eye enables us to see it significantly" (8).

Regardless of the content of a dramatic performance, it is within the realm of the phenomenological that the theatre takes on the Heideggerian sense of "somewhere else," where the space onstage "offers a different kind of here than we "usually tend to be in"" and where what is "disclosed cannot be found elsewhere because it does not exist in nature" (4). The bodies that perform in this peculiar space are imbued with a similar strangeness, as revolutionary (note the small " $r$ ") actors, like revolutionary artists, engage the "distance between experience and the sign language of his art" (100). In this formulation, even familiar places and recognizable characters become foreign, which, for States, helps to distinguish theatrical performance from other art forms. Though States doesn't couch his project in the terms of space and place, his work helps us to see that place was paramount on the early American stage both because the theatre reflected 
the displacement at the heart of early American life (and thus achieved a level of anxietyprovoking mimesis) and because the stage was inherently dislocated in its phenomenology. While all theatre takes us "somewhere else," the early American theatre was distinctive in its capacity to comprise both a mimetic and phenomenological placelessness.

We find evidence for this in the British-ness of the early playhouse. "Enliven[ing] the wilds of America" links performance to an idealized image of the nation as free from outside influence, but these performers were British actors who had been assigned parts "both private and public, behind and before the curtain" (Dunlap 11; Hornblow 73). When, in 1787, Thomas Wignell took the stage as Jonathan, "the quintessential American" in Royal Tyler's The Contrast (the first professional American play), audiences needed to overlook the fact that Wignell's "commitment to America was more monetary than anything else" (Richards, "Introduction," xx). The play's preface locates Tyler as a home-grown playwright, though the fact that Wignell speaks these words from the stage reminded audiences that the definition of what it meant to be an American was being contested: "Our Author pictures not from foreign climes," Wignell proclaims, "The fashions or the follies of the times; / But has confin'd the subject of his work / To the gay scenes - the circles of New York" (7). ${ }^{4}$ Could the "circles of New York," withstand this pressure to be representative of an entire nation, and what might this mean for a city that was occupied by British troops for the entirety of the Revolutionary War? That these words were spoken onstage by an actor who may have been outfitted to resemble an English country rustic rather than a colonial country bumpkin would have only further muddied the distinction between Americans and the British. ${ }^{5}$

To be sure, the British-ness of the American theatre was itself a symptom of the more general persistence of anglophilia. Though early American literature tends to be defined by its 
patriotic works, Philip Gould reminds us that "what distinguished Patriots from Loyalists was not who embraced English culture but how they did so" (8). In the late eighteenth-century, British plays could be found readily in print form, such as in Enoch Story's American Theatre (Richards, "Print," 73). As Story's title suggests, the early theatre was, for the most part, only American in name. Even those who would have considered themselves Patriots, for instance, recovered the "pleasurable identifications with the social world of Britain" that, when remembered after the Revolutionary War, represented an "elegiac fantasy of rank, stability, and paternal authority" (Tamarkin xxviii). This fantasy would have found its incarnation in the ballrooms, card tables, and tea rooms within the early nineteenth century playhouse, and in the stage productions that became associated with wasteful excess. In The Gleaner (1798), Judith Sargent Murray lists "exorbitant expenditures" as second behind only "waste of time" as "foremost in the catalogue of objections" leveled at the stage (185). Such complaints became shorthand for the more widespread fear that anglophilia might impede American identity formation, and the stage the site where British-ness spilled over from the texts being performed to the actors—-like Wignell—who embodied the threat. Just as important, audiences must have experienced the British-ness of the early theatre as a dislocated repetition of the London stage, with such performances more often registering as imitative than as indicative of the "new world."

Even as the early stage progressed to rely less on British actors, American identity formation was complicated by the ways that actor and character became conflated. Marvin Carlson refers to this process as "ghosting," which occurs when an actor reaches such heights of celebrity that he or she becomes "entrapped by the memories of the public" (9). In 1829, Edwin Forrest attained this level of stardom when he performed the title role in John Augustus Stone's 
Metamora, or, The Last of the Wampanoags. In the words of Matthew Rebhorn, Forrest "merg[ed]...a 'savage' voice with a 'savage' performance," and in so doing he revealed "not the univocality of American nationalism, but rather the cacophony of voices articulating what it meant to be American" (455-58). When he played Spartacus two years later in Robert Montgomery Bird's The Gladiator, Forrest disappeared so fully into the role that it became hard for audiences to separate the actor from the role (McConachie 91). Taken together, the immense popularity of these two performances emphasizes the audience's desire to determine what it meant to be American. However, the fact that Forrest could slide so easily from one version of American essentialism-Metamora — to another-Spartacus—suggests that spectators were not ready to embrace this "cacophony of voices." Instead, audiences adopted competing versions of American identity, leading one to wonder if being American meant performing a very mutable version of American citizenship.

Despite the identity crisis playing out on the stage, the prevailing line of inquiry in studies of early American drama has been to explicate the ways that performance-theatrical and otherwise - reinforced the larger political movement toward American sovereignty. Thus Christopher Looby's Voicing America argues that the Declaration of Independence both referred to the nation-state and performed it into being, and Jeffrey Mason argues more broadly that "American nationality is especially susceptible to performance, for insofar as the nation itself is the production of invention or design, its nationality is a consequence of imagination and an object of negotiation" $(23 ; 2)$. If political documents took on performative meanings for early Americanists, the reverse was also true as dramatic works and theatrical performances were positioned in relation to political events. Jared Brown's Theatre in America During the Revolution, for example, claims that most dramas in the years leading up to the Revolution 
should be studied as propaganda pieces rather than as works of art (71). A more nuanced view is offered by Jeffrey Richards, who finds the hybridity of post-revolutionary America reflected in the playhouse, making the case that because American stage identity was so often borne of British drama, we ought to see "American identities rendered as variants of British" source texts (Drama 21).

The theatre has always, to a certain degree, been linked to the nation in the eyes of its citizens. An analogy might be drawn to those spectators in the theatron ("seeing place") of ancient Greece whose view included not just the events onstage but also a "panoramic landscape that extended to the sea in the distance" such that "the eye was not restricted to the interior of the theatre but rather was situated to see the theatre as part of the larger world whose drama was symbolically played out on stage" (Brockett 28). Though the playhouse structures differed in the U.S., audiences attended shows for more than simple entertainment; they came to look out across the symbolic national landscape and hoped to envision what America might become. Even in the years when the theatre was shuttered during the Revolutionary War, early Americans used the theatrum mundi in their writing and speech to define themselves and their place in history through a metaphor that combined theatrical and geographic space (Richards, Theater, 8). What audiences found - and what distinguishes the early American theatre from the theatron of Ancient Greece — was a theatre that reflected the liminal state of early American life back onto them rather than allaying their anxieties of place. It is worth pausing to define the double entendre of a liminal state, which encapsulates macro-level political and geographic connotations as well as individual states of being. In Victor Turner's anthropological study, liminality engages both spatial and temporal dimensions as a "complex sequence of episodes in sacred space-time" (27). That is, the ritual performances of liminality have a clearly defined 
beginning and ending (as in a Mardi Gras festival) and a distinctly defined space of articulation (for instance, New Orleans' French Quarter). Within these limits people find it possible to subvert established norms, to play. This subversion lies at the heart of Joseph Roach's Cities of the Dead, which locates liminality as embodied through "vortices of behavior" which are "situated in the penumbra of the law, open to appropriation by both official texts and hidden transcripts" (64).

However, while scholars who adapt Turner's work often focus on the "full social satisfaction" that results from cultural ambiguity, most seem to have lost sight of the fact that liminality is, at its core, a deeply "ambiguous state" of anomie that can just as often be the "scene of disease, despair, death, [and] suicide" (Turner 46). ${ }^{6}$ I argue that the early American liminal state was more anomic than liberating at least in part because there was neither a clear beginning nor end. Though the Declaration of Independence intended to turn British colonists into Americans overnight, this process was far more fraught than one might expect. Nor did this liminal state occur in a clearly defined space of articulation, as evidenced by the shifting geographic realities that were being negotiated in the years following the revolution. The proliferation of national maps that followed the Land Ordinance Acts of 1785 and 1787 led antiFederalists to emphasize the "large distances [that] separated the states from each other, [which] would prohibit political participation inside the union..., hindering the union's task to supervise the new citizens or to reconcile federal and state interests" (Brueckner 132). Indeed these geographic realities still hadn't been settled as Confederate and Union soldiers fought for the right to re-map the U.S. territories.

As a result, the early American theatre was far better at locating and labeling others as foreign than it was at offering a coherent image of American citizenship. We might connect this 
facet of the early theatre to the triangular nature of what Dana Nelson terms the imagined fraternity of white men. It is through this "imagined affiliation with other men who have power over groups of people" that white males find "the power to objectify, to identify, to manage" (3). To anticipate chapter 4 , this most often occurred in the form of dramatic depictions of racial difference, as in Uncle Tom's Cabin (1852) and The Octoroon (1859), which resituated the South, its slaves, and lingering Native Americans as foreign to Northern theatregoers. Thus nonwhite bodies were effectively disenfranchised and displaced, both literally and figuratively, during stage performances that many associated with the fight for abolition.

The theatre thus played a key role in a broader cultural process of exclusion. While, in Matthew Frye Jacobson's words, "Caucasians are made and not born," many of the nationbuilding exercises in early America set out to construct a system based on disguising this fact (4). From the Declaration of Independence ("all men are created equal") to the Naturalization Act of 1790 (citizenship for "free white persons" only) to the Dred Scott decision of 1857 (denying citizenship to blacks), U.S. citizenship, like the nation's geographic boundaries, was in a nearly constant state of revision. Between the Revolution and the Civil War, this process served one over-arching goal: to uphold a power structure predicated on being white and male.

Those who fell outside this structure, such as Mercy Otis Warren (the focus of chapter 2) and Charlotte Barnes (the focus of chapter 3), worked within the culture of patriarchy but employed strategies to revise the provisional citizenship offered to women at the time. Warren wrote from domestic spaces (i.e. the home) and within seemingly domestic modes (letters, closet drama) but joined the very public debate over American independence and the role of women in this movement. Barnes' The Forest Princess may have found the professional stage, but in attempting to re-historicize the Pocahontas myth, she struggled to balance the melodrama 
audiences demanded and the republican imperative that she, as a woman, should be a bearer of historical memory. Just as Warren and Barnes worked through the "acceptable" modes of writing to stake their own claims to citizenship, so too did a black writer like William Wells Brown (the focus of chapter 5). At the height of minstrelsy's reign on the American stage, Brown found himself incorporating stock minstrel characters into his own dramatic works even as he exposed the hypocrisy at the heart of slavery in the South and racism in the North.

The chapters that follow set out to formulate various answers to a set of over-arching questions: Why did Warren, Barnes, Brown, and others choose the dramatic mode to illustrate their views on who should count as American? How did the dramatic form (and, in some cases, embodied performance) empower and constrain these playwrights? Finally, how was the placelessness at the heart of early American reflected in the dramatic texts and performances from this period?

Chapter one traces Mercy Otis Warren's political closet drama-most notably The Adulateur (1772) and The Group (1775) — to investigate the ways she used this seemingly domestic dramatic mode to not only engage the public sphere of revolutionary America but also to resituate the disembodied public sphere idealized in the eighteenth century republic of letters, later described by Jurgen Habermas. During a period when theatre was literally displaced by anti-theatrical law in Massachusetts, Warren uses the idea of the theatre and the deictic function inherent to the form to insist on the importance of female embodiment in public discourse, a move that anticipates modern feminist and queer critiques of Habermasian principles.

Once the theatre re-opened, early American playhouses became sites where the nation's origins could be performed, most notably in the proliferation of Pocahontas plays. Chapter two highlights the persistence of the Pocahontas myth as a foundational national narrative from 
James Nelson Barker's The Indian Princess (1808) to Charlotte Barnes' The Forest Princess

(1848). For Barker, the Pocahontas narrative stages the transformation of American space into a world stage, a stage that is invoked and embodied by the specifically white bodies that inhabit it. Where Barker largely sets aside historical veracity for melodramatic flair, though, Barnes imbues her dramatic text with historical research as evidenced by the footnotes she includes in the dramatic text, and a final act that follows Pocahontas' displacement from her native land to London. Yet in this final act, Barnes' historical project is largely displaced and as the play takes on more melodramatic features, The Forest Princess becomes fragmented, offering sensational allegory rather than historical veracity. I will suggest that Barnes' discomfort with the placemaking mythology that Barker so readily embraced might be best understood as a deep-seated ambivalence about the transformation of spatial discourse into theatrical space. The fact that her play succumbs to this very transformation highlights an inherent conflict between dramatic aspirations to supplement the historical record and the melodramatic mode, which evolved to become increasingly at odds with attempts to place history onstage.

Taken together, these two chapters introduce a larger claim, that because theatrical performances served as a site where anxieties of place were as often further provoked as ameliorated, a writer like Warren was able to skirt the limitations of the stage by using the idea of the stage, but her project succeeded largely by never entering the playhouse. It wasn't simply the case that Warren's closet drama couldn't be put on stage due to the legislative ban on theatrical entertainment but that she found in the dramatic form and the conceptual space of the imagined stage a mode of address that more efficiently conveyed an alternative to the disembodied public sphere. On the other hand, Barnes' inability to create a cohesive and historically accurate melodrama can be read not so much as a personal failing as it was a failure 
to recognize the power of the playhouse as a site that insisted on transforming spatial discourse into theatrical display, even for a playwright who set out to avoid this pitfall.

In chapter three I first examine a set of disparate texts-Susanna Rowson's play Slaves in Algiers (1794), Royall Tyler's novel The Algerine Captive (1797), and Robert Bird's play The Gladiator (1831) — that depict slavery in foreign lands. I compare these works with two staged plays that dramatized Southern slavery, George L. Aiken's Uncle Tom's Cabin (1852) and Dion Boucicault's The Octoroon (1859). It is my contention that Uncle Tom's Cabin and The Octoroon built on the tradition of Rowson, Tyler, and Bird, of depicting slavery in foreign lands by resituating the South and its slaves as foreign to Northern theatregoers. Finally, I discuss the anxiety provoked when audiences find themselves sympathizing with these displaced, "foreign" characters. In this chapter, then, we see the early American playhouse as a site where even abolitionist plays contributed to the disenfranchisement and displacement of the men and women who would continue to struggle for a sense of place in the nation long after the thirteenth amendment set them free.

Re-orienting spatial discourse through dramatic space required performers to move outside the theatre altogether. In chapter four, we exit the playhouse to re-imagine William Wells Brown's lecture performances of The Escape (1858). By delivering his play as part of a lecture tour, and by performing in churches and courthouses, Brown implicitly questions the political efficacy of the antebellum theatre. More specifically, Brown challenges the notion that staged melodramas in the antebellum period could adequately represent the violence enacted when white masters and slaves shared space. Given the fact that black and white spaces tended to be segregated on the melodramatic stage, Brown's one-man performances collapsed the slave quarters and the master's parlor, and he did so in locations associated more with religion and 
politics than entertainment. Through both the dramatic mode and these sites of performance, Brown troubles the segregated spaces of traditional antebellum theatre and achieves something that stage melodramas could not: a performance of miscegenation that confronted audiences with the sexual violence intrinsic to slavery.

***

One of the most compelling aspects of drama is its capacity to change. As the earliest historian of the American theatre, William Dunlap notes that even in its relative infancy, change was evident: "The first efforts at dramatic literature in this country were wild....Both the dramatists and the people they addressed had not yet sufficiently matured their notions of the results of the great political changes which had taken place" (90). This is a distinctly different view than Dunlap gives us at the end of his history, where he compares the theatre to "a mighty engine [that] was introduced among us" (405). From the "beginning" to 1832 (where Dunlap's history leaves off) the theatre adapted to changing national ideals, evolving from a reflection of America as wild and blank, to, in his later estimation, an outgrowth of the industrial revolution. Nor has the desire to describe this aspect of performance waned in the ensuing years. For Bert States, theatre is "a predatory institution" that "feeds on the world as its nourishment,... adapts to cultural climate and conditions that necessitate period shifts in direction and speed, and finally exhausts itself and dies" (13).

Just as compelling, though, are the ways in which the theatre reinforces the status quo and the ways that particular anxieties and ideologies persist despite performance's proclivity to adaptation and change. My hope is that we might be inclined to look back through these points of transformation to William Hallam's company, rehearsing Shakespeare on the deck of the 
Charming Sally, and that we might see it for what it was: a performance of placelessness that would reverberate through the American Revolution to the eve of the Civil War. 
Notes

${ }^{1}$ There is some disagreement about what led Hallam to send his company to America. William Dunlap claims that Hallam went bankrupt when David Garrick took his company_and his growing popularity_-from Goodmans' Fields Theatre to Drury Lane. Hallam succeeded Garrick at Goodmans' Fields, according to Dunlap, and this theatre quickly went bankrupt. Hornblow finds no evidence that this happened, and instead argues that the Goodmans' Fields Theatre was closed in 1742, and that Hallam likely managed another, unnamed theatre (72).

${ }^{2}$ Hornblow notes that Dunlap got this information directly from one of the Hallams.

${ }^{3}$ Fliegelman's pairing of the body and text anticipates Gustafson's “performance semiotic of speech," in which the interplay of speech and writing yields performative meanings (xviii).

${ }^{4}$ By opposing "foreign climes" with the audience's "patriot hearts," Tyler posits New York as synecdoche for the United States, a move that complicates the playwright's explicit intention to craft a drama that "we may fairly call our own" (7).

${ }^{5}$ Francis Hodge points out that William Dunlap engraved an "English" Jonathan, wearing "a darkish uncombed wig, a long coat, knee breeches, plain linen to contrast with the fancy linen of the city characters, and black stockings" (NP). Still, this is the only known description that points toward an "English" Jonathan, leaving scholars to wonder if this was merely a one-off rather than a consistent wardrobe choice.

${ }^{6}$ In Cities of the Dead, for instance, Roach summarizes Turner's definition of liminality thusly: "As further developed by Victor Turner, the concept of liminality—a state of betwixtand-betweenness, a 'subjunctive mood' in the grammar of communal activity_characterizes as 
'social dramas' those behaviors in which normative categories are transgressed or suspended only to be reaffirmed by ritual processes of reincorporation." "Turner and others," Roach continues, "have hypothesized that celebrations of death function as rites of social renewal" (37). Nowhere in this description does Roach even hint at the darker side of liminality. 


\section{Chapter One: Resituating Public and Private Space: The Political Drama of Mercy Otis Warren}

Mercy Otis Warren's The Group (1775) contains a curious subtitle for a work of closet drama: "As lately Acted, and to Be Re-Acted to the Wonder of All Superior Intelligences, Nigh Head-Quarters at Amboyne" (29). To explain this oddity, Amelia Howe Kritzer claims in a footnote that "Warren sent the manuscript, in scenes, to her husband, an officer in the Patriot forces, and it may have been given a dramatic reading in his camp" (29). It is worth pausing over this admittedly speculative though revealing possibility: if true, we might reconstruct The Group as a kind of one-actor dramatic reading of a politically divisive play, performed by an officer for an audience of soldiers who were engaged in war with a rival nation on American soil. That such a possibility becomes a mere footnote in an out-of-print anthology is quite surprising when one considers the critical discussions that this performance might elicit: this bit of buried theatrical history takes place well beyond the walls of metropolitan America, challenges popular associations between closet drama and domestic texts, and speaks to the imprecisely defined national borders during the Revolutionary War. Despite these fruitful avenues for critical discussion, Warren's closet dramas — of which The Group was only one — have largely escaped the notice of scholars in American literature.

In Warren's own time, John Adams worried that her work might be lost to future historians. We know, for instance, that in August of 1814, a nearly eighty-year-old Adams made the ten-mile journey from Quincy to the Boston Athenaeum to handwrite Warren's name into a copy of The Group (Richards and Harris 23). Adams saw something of value in Warren's closet drama, and he felt her authorship merited preservation alongside the periodicals, newspapers, and texts, like David Hume's History of England - one of the earliest texts housed in the library 
(Influence 25-6). Why, though, did he deem it necessary to link Warren's name to this text during a period of American history when authors were increasingly disconnected from the texts they published? What did Adams fear would be lost to history if The Group was committed to posterity as an anonymously authored political drama?

In attempting to answer these questions, we must first come to terms with the relative absence of critical work on closet drama in revolutionary America. The lack of critical discourse is particularly surprising given the fact that these texts were not only reasonably popular, but also accessible to those who weren't able to attend the theatre either due to geographic distance or as a result of legislative decree. I contend that the lack of scholarly interest in texts like Warren's persists for two primary reasons: first, because eighteenth century closet drama continues to be mislabeled (and denigrated) as a domestic genre, and second, because of the otherwise welcome critical shift in early American studies towards less text-centric scholarship. Christopher Looby, for instance, challenges us to redefine the balance of power between print and performance, by arguing that "the widespread cultural investment of authority in vocal forms like political oration and sermons created a counterpoint of anxiety about the sufficiency of textuality as a ground of authority" (44). In Eloquence is Power, Sandra Gustafson puts text and orality into dialog with one another through what she terms the "performance semiotic of speech and text." For Gustafson, meaning can be most accurately derived not from speech or text alone, but rather from the interplay of speech and text (xviii). ${ }^{1}$ These studies of cultural performance through orality and print have only begun to trace the myriad ways that print and performance interacted in early America, but they have had a clear influence on the direction of early American scholarship. $^{2}$

In the concerted effort to avoid privileging print, early American closet dramas have been 
largely ignored in favor of texts that were put on stage. Those who do bring closet drama into their discussion of the relationship between performance and dramatic publications tend to make an unnecessary distinction between public and private spheres, which are in turn overlaid with distinctions between entertaining performances and closeted texts. In this conception, theatres are sites of public entertainment and closet dramas spring forth from the private sphere as domestic tracts that are unrelated to stage performance. In an effort to move away from this oversimplification, I draw upon Jurgen Habermas's descriptions of the burgeoning public sphere and the environments that were conducive to this shift. Locating the signs and symptoms of the Habermasian public sphere helps us see stage drama as something other than "public," so as to locate closet drama as something more than "private."

I will then examine the publication history of Warren's The Adulateur (1772), a work of closet drama that was first excerpted in newspapers. While circulating The Adulateur in print enabled Warren to engage the public sphere in ways that the theatre would not allow, this came at a significant cost. The subsequent plagiarism of The Adulatuer by an unknown author highlights the lack of authorial control when a work enters the world of print and-in the absence of clear copyright law-is appropriated by another author. This plagiarism troubled Warren for she was already marginalized and placed in a position where her voice risked being lost. I will suggest that Warren responded by resituating the disembodied ideal Habermasian public sphere where political debates are set out for discussion unattached to interested persons. I read The Group (1775) as an attempt to wrest back authorial control and an effort to re-embody the public sphere through the metaphor of the actual stage with its insistence on gendered embodiment. It should be noted that she achieved this not in spite of the legislative ban on playhouse performances in 1774 , but because of the displacement of the stage during this period. 
Warren thus resisted "popular eighteenth-century associations of the closet with privacy and domesticity" as she carved out a place for the female body on the metaphorical stage and subsequently re-envisioned domestic spaces as sites of public engagement (Ready 186).

Warren's project anticipates more recent feminist and queer critiques of the Habermasian public sphere, which seek to uncover those who resisted - and continue to resist - the conception of an all-encompassing public. Nancy Fraser calls into question the oversimplified distinction between the public sphere and domestic spaces, finding that the exclusion of women from the public sphere, in Habermas's conception, amounts to accepting "at face value the bourgeois public's claim to be the public" (61). Michael Warner similarly stresses the need to differentiate between $a$ public and the public, as he calls for a "different social imaginary" where counterpublics can secure agency independent of their relationship with the state ("Publics" 89). My hope, then, is that through these lenses we might locate in Mercy Otis Warren's closet drama clear evidence that the recent critical call for a "different social imaginary" builds on the work of early American writers like Warren, lending credence to Fraser's claim that "there were competing publics from the start, not just from the late nineteenth and twentieth centuries" $(61) .^{3}$

\section{The Problem of Print in Early America: Competing Discourses on Closet Drama}

As scholars pair performance studies with dramatic publications - the path of closest contact between performance and textuality — these dramatic texts remain a troubling test-case for theatre historians. This is especially the case when studying the U.S. in the late-eighteenthcentury given the ubiquity of dramatic texts that circulated in a variety of mediums, from excerpts printed in newspapers, to closet drama, to dramatic works that were printed and disseminated in conjunction with local performances. 
The wide variety of forms that dramatic print assumed is, in some ways, a microcosm of larger print practices in revolutionary America (and abroad), practices which were becoming more complex with the rise in publications and increase in readers, in a nascent, increasingly global economy based on exchange. As R.C. Nash points out, "From the 1730s [on]...there was a huge increase in the volume of capital advanced to the colonies by the specialist groups of commission agents who dealt with each region... where commission agents lent capital sums to tobacco and, above all, sugar planters that dwarfed the loans made before circa 1730" (123). An analogous rise in print culture occurred within this burgeoning credit economy, which cemented a cultural link between the symbolic economies of paper currencies and papers of a more literary persuasion. Mary Poovey finds, thus, that in Britain "the overlapping takeoffs in the production of bank paper and that of book paper were not strictly coincidental...[as both] thrived on the credit represented by the expansion of paper notes and prospered, in part, because of the commodification of a wide range of fashionable and leisure products, including books and pamphlets" (155).

The result of these concurrent trends was that goods, ideas, and texts were exchanged in a global marketplace, pushing our understanding of print beyond the "hub-and-spoke" model of exchange. "The emerging Atlantic economy," writes David Hancock, "was decidedly multilocal and, even at larger-scale levels, ambivalently non-metropolitan" (31). On the one hand, the move away from traditional models may align more neatly with early American performance practices. For instance, Odai Johnson ventures outside metropolitan regions to detail the often itinerant nature of troupes in America before 1760 where "strollers" formed "fugitive companies" capable of disrupting local economies by carrying "local" money from one town to the next (Absence 24). Casting our gaze beyond metropolitan hubs may also allow us to look with fresh eyes upon 
theatrical histories, which have been overshadowed within major cities. In an illustrative example, Marvin McAllister recovers William Brown's Pleasure Gardens, a long neglected though key part of New York's rich theatrical history, and a site for “Afro-New Yorkers [who] needed supportive gathering spaces...in which to rehearse dominant social sensibilities and to 'self-create' a liberated Afro-America” (35).

The critical shift away from a hub-centered approach, however, does present problems in relation to theatre history, particularly with regard to the print materials used to reconstruct this early period. Most notably, as one moves further from metropolitan centers, surviving print materials that document local performances prove scarce as already fragmentary evidence becomes even more unlikely to survive. While the "problem" of extant texts from the early national period goes well beyond works of drama, the concentration of evidence from the relatively theatre-rich cities of New York, Philadelphia, and Boston is offset by the relative absence of theatrical histories in more provincial regions of the U.S. Material evidence such as playbills functioned as vital "point[s] of contact between the public and the players" yet they have survived only rarely, and in less populated colonial towns the absence of local newspapers severely limits our efforts to uncover provincial theatrical histories (Johnson, Absence 54, 150). If it is true that "the history of performance is marred by its own absence," the movement away from a hub-and-spoke model and towards a multilocal model will likely continue to present archival challenges (Johnson, Absence, 215).

Even in cities like Boston, though, the idiosyncratic publication practices of the late eighteenth century make it difficult to chart a clear or consistent model of dissemination. "It is important to remember," writes Eve Bannet, "that in America there was a double economy of the book: alongside the volumes carried over the water by the transatlantic book trade, there was... a 
'native fabrication' or 'literary manufacture' of books [being]...re-told, re-interpreted” (3). Thus even in an increasingly global financial marketplace, at the local level those acquiring cultural materials were free to use (and reuse) such materials at their own discretion, especially given the fact that copyright laws were not enacted in the U.S. until 1790, laws that were difficult if not impossible to enforce (Baker 165). "The presence and circulation of a representation," writes Michel de Certeau, "tells us nothing about what it is for its users...for we must first analyze its manipulation by users who are not its makers" (xiii). When examining texts from revolutionary America, we find an abundance of manipulated texts that are ready for this kind of analysis.

The circulation of print drama was more complex than even the "double history of the book" as described by Bannet. As dramatic texts became more ubiquitous, the interaction between text and performance became more pronounced. In Boston, New York, and Philadelphia, for instance, "the circulation of printed scripts...made audiences very knowing of what they would see and critical when actors missed lines," a system that "inspire[d] local writers to seek print as well as performance for their works" (Richards, "Print," 76). Indeed, audiences often viewed performance as embodied rehearsals of dramatic texts. In his History of the American Theatre, William Dunlap describes those who "had only read the works of Shakespeare [and] were anxious to experience the influence of the living personification of those thoughts and characters which had delighted them in the closet" (19). Of course, this clear connection between print and performance wasn't specific to the American theatre, and the influence was hardly unidirectional. Julie Stone Peters posits that as early as the sixteenth century in England, "printers seem to have come to rely on a readership familiar with both the theatre and the typographic conventions of drama," a movement which intensified "the drive towards the conventionalization of dramatic form that print had already set in motion" (24-6). 
Similarly, colonial script formats were based on prompter notes from local performances, contributing to the standardization of printing practices for dramatic texts (Wilson 164).

Dramatic publication practices were made even more complex by the British-ness of the early American stage. Popular British dramas often were carefully revised for an American marketplace, such as John O'Keeffe's The Poor Soldier (1783), where changes included cutting a French character that was interpreted as a "slur on the late allies of the country," a move that reflects the highly-charged political climate of the day (Richards, Drama, 69). In William Dunlap's Andre (1798) (a work adapted from Thomas Otway's Venice Preserved [1783]), the relationship between male leads is complicated in the American version by Dunlap's decision to downplay the role of women in the play, which allows for a highly charged homo-erotic (or at the very least, homosocial) performance (Richards, Drama, 130). Other, more recent theatrical histories have followed this productive line of inquiry. In Rogue Performances: Staging the Underclass in Early American Theatre Culture, Peter Reed reminds readers that American plays based on British sources must be viewed as "found documents," and he describes the "porous boundaries" of print and performance culture where "the archive and the repertoire frequently appear intertwined" (24) This is a provocative statement, and one that reflects a larger push from early American scholars to see text and performance as mutually influential. Or, perhaps more accurately, these works remind us that early Americans experienced a shared ecosystem of print and performance.

Where, though, does closet drama fit within the larger framework of publication practices in the early republic? Answering this question is made more difficult because closet drama lacks a clear or even consistent critical definition. Closet dramas have often been conflated with "other related, but distinct, terms" such as poetic plays and dramatic poems, which is only possible if 
we "ignore the circumstances of the play's creation... [and] bypass the issue of "intent"" (Burroughs 216-17). Beyond enveloping a wide array of dramatic forms, Kathryn Ready surveys the term's adaptability and finds that, "historically, the term closet drama has been employed variously to designate drama intended to be read silently or aloud as opposed to performed, drama intended to be performed in alternative venues to the commercial theater, drama considered unstageable for various reasons, and drama rarely performed but still preserved for its literary value" (186). While such inclusive definitions open up the possibility of recovering ignored works, closet drama's unruliness and malleability more often lead scholars to see these texts as cultural outliers, worthy of preservation but not investigation. ${ }^{4}$

One way to begin this recovery is to note the connections between closet drama and theatrical performances. In fact, the rise of closet drama occurs not in a vacuum but rather in direct response to the demise of the playhouse. Historians of the British theatre often make a causal link between the Stage Licensing Act of 1737 and a resulting increase in the exchange of closet dramas in Great Britain. As Catherine Burroughs points out, the Licensing Act "restricted the performance of Britain's canonical theatre to Covent Garden, Drury Lane, and to the summer Haymarket" and it institutionalized "the Lord Chamberlain's role as censor" but "alternative venues and modes emerged" (221). No mode that emerged was more prevalent than closet drama, which benefitted greatly from the displacement of the professional theatre.

American dramatic history tends to follow a similar trajectory, based on its own legislative attempts to curtail the theatre. In 1774, as the war with Great Britain escalated and in response to fears that the theatre was a site of "British tyranny and elitist luxury," the Continental Congress banned all theatrical entertainments in the "first 'national' stance taken against the theater in America" (Nathans 44, 37). ${ }^{5}$ Far from muting the desire of Americans who wished to 
read dramatic texts and see theatrical performances, the closing of theatres in Boston, New York, and Philadelphia, unleashed the pent up demand for stage performances in the guise of a growing market in closet dramas.

Closet dramas joined the many other published texts circulating in a burgeoning public sphere that, in Jurgen Habermas' view, privileges writing as the "constitutive medium of the...public sphere because writing allows ideas to be presented independently of the persons who authored them" (Maslan 29). Emphasizing the medium of print (in place of the speaking subject), Michael Warner elaborates on this key facet of the Habermasian public sphere: "Social authority, like truth, holds validity not in persons, but despite them; it is located not in the virtuous citizen nor in God nor in the king, but in the light of day, in the supervision of publicity itself" (Letters 82). Thus, in an oft-cited example, Benjamin Franklin's "Silence Dogood” letters illustrate the relationship between the public and print, as Franklin's fictional persona can "see without being seen" while she also "exemplifies the republican stoicism of publicness in the regime of supervision" (Letters 85). To accept the possibility of both these characteristics at once is to conceive of a public as a disembodied ideal, free from the constraints of the body, as evidenced by his decision to adopt a female authorial persona.

It is, in my estimation, no coincidence that closet drama takes off in popularity at the same time that the public sphere develops through print in early America. This had as much to do with the inherent form of closet drama as it did with the increased circulation of print materials. The imagined theatre of closet drama offered writers a virtual space where ideas could be put forth in a way that emphasized, much like Franklin's Silence Dogood letters, a fiction of seeing without being seen. More so than poetry or prose, drama utilizes a clear deictic function, pointing away from the playwright and towards the speaker of a particular line, and so writers could use 
closet drama's most recognizable feature to claim their own social authority. In sum, playwrights were able to take advantage of two events - the closing of the professional theatres and the rise of the public sphere - through a genre that perhaps best achieved the republic's early goals.

\section{Private Theatres, Public Spheres}

As print (including closet drama) increasingly became associated with the public sphere, the early American theatre moved in the opposite direction, towards the private. In The Structural Transformation of the Public Sphere, Habermas outlines three "institutional criteria" needed to create a public: a level of inclusivity, a disregard of status, and a shared "domain of common concern" (36-7). The question of inclusion is perhaps the most difficult criterion to pin down, and Habermas is careful to define this inclusivity as existing on a spectrum rather than as an absolute condition:

However exclusive the public might be in any given instance, it could never close itself off entirely and become consolidated as a clique; for it always understood and found itself immersed within a more inclusive public of all private people [emphasis mine], persons who - insofar as they were propertied and educated - as readers, listeners, and spectators could avail themselves via the market of the objects that were subject to discussion. (37)

As we will see, the revolutionary theatre fails this test on two fronts: the theatre was more exclusionary than inclusive, and the larger macro environment of early America - with its spatial and geographic disruptions - failed to provide a structure cohesive enough to comprise a "public of all private people." That is, the revolutionary theatre itself was not immersed in anything cohesive enough to be called a public. 
To be fair, this transition towards exclusion followed a similar shift in global performance practices. In pre-modern performances, which most often took place outside of permanent theatre structures, the public-ness of performance was paramount. Marvin Carlson charts the sites of performance from the city as theatre to the playhouses of modernity, finding that in the late Middle Ages processions were common, and as these "dramatic pageants" moved through the city streets, an implicit claim was made "for the involvement of every citizen" (19). A clear shift occurs, however, in the Renaissance, as street performances diverge from "the institutionalized theatre of polite society," and this division becomes more pronounced in modernity (27). During the British Interregnum, for instance, performances continued in the private homes of those wealthy enough to become patrons. Indeed, as Carlson argues so forcefully, performance history repeats itself across nations and cultures. "When state censorship created problems for theatrical presentation," writes Carlson, "private spaces within dwellings were often utilized" (49). Thus in times of political strife in London, the play went on, albeit only for those who moved in well-heeled social circles. ${ }^{6}$

Early America's Interregnum set in motion its own shift in sites of performance once the playhouse was shuttered. The ban on theatrical performances by the Continental Congress in 1774 (renewed in 1778) was a legislative attempt to break free from the tyranny of British culture, an understandable response given the abundance of British plays hitting the boards in the new nation. This edict was meant to both stimulate patriotic sentiment in America and guard against the financial waste of theatre in war-time when the nation was on uncertain fiscal footing (Nathans 37). ${ }^{7}$

Where the ban on theatrical entertainments in Britain forced performances into upperclass homes, though, those who defied the Continental Congress's ban did so in performance 
spaces that resist easy definitions of private or public. Jason Shafer finds that even in the absence of David Douglass' American Company, performance found new venues, such as on “colonial campuses [which acted] as incubators of both early American performance culture and Revolutionary political sentiments" (107-8). In fact, "Nowhere was the acceptance of academic drama so popular as at the colleges of those very regions who sought so vigorously to suppress the theater: Harvard, Yale, and the College of Philadelphia" (Johnson, "Drama," 176-7). ${ }^{8}$ These campus performances might best be described as occurring within a state of exception. For Giorgio Agamben, the exception isn't the "threshold that guarantees the articulation between an inside and an outside, or between anomie and the juridical context by virtue of a law that is in force in its suspension; it is, rather, a zone of absolute indeterminacy between anomie and law" (57). In exceptional performances on campuses, then, student actors performed the "pleromatic state [the state of fullness] in which the distinction among the different powers (legislative, executive, etc.) has not yet been produced" (Agamben 6).

Nor were college dramas the only exceptional performances in early America. Agamben's work on exception is also applicable to performances staged by the British Army and Navy, which were a routine occurrence during this period, much to the chagrin of the colonists who viewed such performances during war-time as an affront against the sanctity of battle. "The colonists," writes Heather Nathans, "wearied by the privations of the war, regarded this as the ultimate insult - that the British should take such a casual approach to the war as to spend more time painting scenery and putting on plays than fighting” (38). Far from worrying about performance as a distraction, these British servicemen used dramatic enactment to proclaim British sovereignty in the face of the law passed by the Continental Congress forbidding theatrical display. That the British conceived of these performance spaces as taking place 
"between anomie and law" is suggested by their surprise when actual warfare encroached on this interstice. On January 8, 1776 British soldiers were moved from a state of exception to a state of panic by news of an American attack that interrupted a performance of a play "written to commemorate their [the British's] bravery" (Brown 28). Following the displacement of the professional theatre in the colonies, the dramatic reading by James Warren to his Patriot camp (detailed at the beginning of this chapter), the plays performed on America's elite campuses, and the war-time shows by the British Army and Navy, offered competing claims to sovereignty through exceptional performance.

The shift from pseudo-theatrical performances on campus and behind enemy lines during war-time in America seems to differ from the movement into private homes following the Interregnum in Great Britain, though the effect was much the same. In fact, plays performed on the campuses of elite universities and on the battlefield, respectively, may be compared more easily than one might think, given the fact that both kinds of performance exclude a large segment of the "public." Just as British theatrical performances were forced into the elite spaces of wealthy patrons, the university in New England became a site where the privileged few could keep the theatre alive. British productions by soldiers on American soil, similarly, offered theatrical displays that excluded not on the basis of nationality but rather on the basis of class. Jared Brown notes, for instance, that Philadelphia's elite became "accustomed to the lavish entertainments and parties furnished by the British military," which suggests that in times of war wealthy Americans sought out performances, even when staged across enemy lines (60).

To follow this line of thought, though, is to assume that traditional playhouse productions were predicated on inclusion, an assumption that simply does not hold up. For one, early American theaters were sustained by a growing class of wealthy patrons who "consolidated their 
power and their fortunes through the establishment of private banks and stock companies," moves which enabled the creation of theatres that exhibited this growing wealth (Nathans 50). Being able to afford a ticket to the theatre was to gain only a provisional kind of access, as even when less wealthy spectators found their way into the theatre, they found themselves excluded both in where they could sit (or stand) and in what areas of the theatre they could frequent. Lower class spectators could not, for instance, visit the ballrooms, card rooms, and tea rooms that sprang up within playhouse (Nathans 72). While historians often link the rise of capitalism in the early nineteenth-century to the fact that audiences were as interested in being seen at the theatre as they were with seeing the play, these late eighteenth-century rooms within the playhouse achieved a similar goal. ${ }^{9}$ Being seen in the theatre was one thing, but being seen entering or exiting such exclusive rooms within the theatre amounted to a higher form of cultural capital. ${ }^{10}$ Far from disregarding status, a key facet of Habermas's criteria, the early American playhouse found new ways to separate play-goers within a structure that already privileged the wealthy over the poor.

We might expect, then, that drama found its public in print if not in performance. Yet scholars continue to frame closet dramas, and in particular those written by women, through "associations...with privacy and domesticity," as an ostensibly less progressive, less public, less politically engaged form of publication (Ready 186). Catherine Burroughs makes this case in a passage that is worth quoting at length:

When one writes closet drama, one can craft a play without having to deal with the politics or economics of theatrical production, one can act, direct, and design without having to be reviewed; one can read—in silence or aloud—without having to accommodate a paying audience, although one can invite an audience in. Furthermore, 
closet drama allows writers (and readers) to fantasize a theatre without consequencewithout real people, without real bodies — and the result is a discrete form that pays homage to a theory of playwriting but not to a practice; to the idea of a staged play but not to its gritty reality." (221-222)

These associations seem to emphasize the closeted writer rather than the closeted text, painting a picture of women playwrights who don't (or can't) stray far from home, and who enter the sphere of print so as to be read by a close-knit coterie rather than the public at large. As I will show, such assumptions overlook the varied publication avenues being opened up for women in revolutionary America and the ways that closet drama could and did engage with more than simply the "theory of playwriting." Finally, in Mercy Otis Warren we find a writer who challenges the assumption that closet drama imagines a theatre "without bodies," as she uses this genre to insist on the embodiment of the public sphere.

\section{Mercy Otis Warren's Political Plays and the Ideal Habermasian Public Sphere}

As a woman writing during the rise of print culture in the colonies, Mercy Otis Warren experimented with anonymous and pseudonymous publication, printed manuscripts and privately circulated texts. Nor were these publication decisions made lightly. Gay Gibson Cima finds that Warren utilized "strategic anonymity," which enabled white women to access the burgeoning print market while avoiding being labeled a traitor or being accused of "slanderous behavior" (473). Mary Kelley similarly finds that these publication practices were strategic, as she argues that early American writers like Warren "moved back and forth between print and manuscript, manuscript and print, as they exploited new opportunities and negotiated traditional constraints" (2). ${ }^{11}$ 
Why, then, has Warren's drama failed to enter this discussion of print in the new nation? In part, the answer lies in the fact that Warren's closet dramas have rarely been given serious consideration in studies of American literature at all. Sandra Sarkela argues that scholars have long overlooked these texts due to a commonly held belief that they were merely unfinished plays, holding open the possibility that Warren intended these works for the stage (543). If these plays were indeed unfinished, the reasoning goes, they can be better studied as political artifacts than as works of dramatic literature. Jeffrey Richards, though, argues that none of her political plays were intended for the stage, as he finds "no evidence that she ever attended a play, certainly not a professionally produced one, and given the hostility in Massachusetts to theater in the years she was writing her plays, there would have been little chance to see one" ("Print" 789). Indeed, with the Act to Prevent Stage-Plays and Other Theatricals of 1750, the General Court of Massachusetts effectively ensured that those in Boston (and Plymouth) would have to travel to New York or Philadelphia — sites of more liberal acceptance of drama — to see a play, especially given the strict punishments laid out in the act. This legislation called for punishment of all who provided "any house, room or place" for performance, even going so far as to call for fines for those who witnessed such performances (five pounds) and those who acted (twenty pounds) (Houchin 28).

Warren may not have visited the theatre, but like most early Americans she was familiar with dramatic texts. As a relatively financially secure woman living near Boston, Warren read widely in the popular drama of her day, most notably the works of Shakespeare and the French playwright Moliére. Warren outlines her attraction to the dramatic form in a letter to Abigail Adams where she praises the genre's ability to engage with political reform: "The solemn strains of the tragic Muse have been generally more to my taste than the lighter Representations of the 
Drama. Yet I think that the Follies and Absurdities of Human Nature Exposed to Ridicule in the Masterly Manner it is done by Moliere may often have a greater tendency to reform Mankind than some graver Lessons of Morality" (qtd. in Richards, Theater, 225). This was a bold commentary as Warren reflected on the literary merits of the dramatic form in the same year1774 - that the theatres were legislatively closed throughout the colonies.

Before the American Interregnum, drama largely excluded the work of women, as most dramatic performances in the U.S at this time were based on plays written by British men. Later writers such as Susanna Haswell Rowson and Anna Cora Mowatt were able to make the transition from acting to writing plays, but Warren's opportunities to write for the stage would have been limited at best, even before the theatre was shuttered. The rise in political closet drama that coincided with the political disturbances of the American Revolution, though, offered Warren the opportunity to join the conversation in a genre that hadn't yet taken on its associations with domestic spaces.

The discourse on domesticity as a gendered concept in American literature tends to mark off the mid-nineteenth century as the period of inquiry. In Barbara Welter's foundational article, "The Cult of True Womanhood," she argues that women in the period of 1820-1850 were judged based on four "cardinal virtues_ - piety, purity, submissiveness and domesticity" (152). For these women, social reform was to begin at home, and the "true woman's place was unquestionably by her own fireside" (162). The subsequent revival of domestic or sentimental fiction locates its beginnings in the rise of fiction written by and for women, as categorized, for example, in Nina Baym's Woman's Fiction: A Guide to Novels by and about Women in America, 1820-1870.

The critical tendency to label Warren's closet drama as domestic (and by extension feminine), then, amounts to an anachronistic reading that fails to account for the ways that closet 
dramas were received in the eighteenth century. Warren herself worried in letters to John and Abigail Adams that her political drama might be unbecoming for a gentlewoman, which suggests that political closet drama was more acceptable if written by men rather than women, and that the genre hadn't yet taken on its association with a gendered domesticity:

But though from the perticuler Circumstances of our unhappy times A little personal Acrimony Might be justifiable in your sex, Must not the Female Character suffer. (And will she not be suspected as Deficient in the most Amiable part therof that Candour and Charity which Ensures her both Affection and Esteem.) if she indulges her pen to paint in the Darkest shades Even Those whom Vice and Venality have Rendered Contemptable. (qtd. in Richards, Mercy, 95)

Warren may have written her dramas at home, but her closet drama entered a public sphere that forced her to balance gender expectations with her prerogative to lay bare the "contemptable" through satire.

Warren had cause to worry about how her political drama might be received by the reading public. Political closet drama in the eighteenth century-with the notable exception of Warren - was dominated by male authors, a fact that troubles the persistence of critical conversation that links closet drama to feminine domestic spaces. Robert Hunter, the royal governor of New York attacked his political enemies in Androborus (1714), Robert Rogers' Ponteach; or the Savages of America (1766) offered a relatively sympathetic portrayal of Native Americans, while John Leacock (The Fall of English Tyranny [1776]) and Hugh Henry Brackenridge (The Battle of Bunkers-Hill [1776]) reflected on revolutionary battles and American victory (Richards, “Introduction” xii-xiii). By and large, then, Warren didn't join a coterie of women writers by publishing closet drama, but rather a group of powerful political- 
minded men.

Warren's political motivations and her thoughtful decision to try her hand at closet drama should lead us to consider the ways that she used the idea of the theatre to negotiate the political strife of her day. Unfortunately, this was not considered a legitimate possibility even by the scholar most responsible for reviving Warren's work within the framework of American literature. In her 1953 essay, Maud Macdonald Hutcheson begrudges Warren's plays for “lacking in plot, love interest, and women characters," and she reduces the plays to "rabid conversation pieces, propaganda, intended primarily for reading" (383). To be sure, The Group consists in its entirety of a series of speeches and lacks any real sense of dramatic plot, but Hutcheson's essay fails to situate these political plays in relation to the early American stage.

In fact, there is evidence that Warren made the conscious choice to write closet drama for strategic reasons, not least of which was the desire to join so many other revolutionary writers for whom theatrical performance represented "a conscious, common, often deliberately developed figure" (Richards, Theater, 291). In a May 24, 1773 edition of The Boston Gazette, Warren introduced an excerpt from The Defeat, writing, "As many of your Country Readers have been out of the Way of the Theatrical Amusements of the last Season, it may perhaps be some Entertainment to them to see a few Extracts from the Defeat, a Dramatic Performance lately exhibited" (qtd. in Sarkela 553). Sandra Sarkela argues that "the words 'Dramatic Performance' should be read as a reference to Hutchinson's real-life 'performance' as governor," rather than a reference to an actual performance of this closet drama (553). Warren used the metaphor of the stage, like John Smith and Cotton Mather before her, as "a means of speaking about providential history in nationalist terms" (Richards, Theater, 205).

Warren's metaphorical use of the theatrical performance, though, distracts from the ways 
that she incorporates allusions to the debate surrounding the actual theatre during the revolution in her closet drama. Theatres, as we have seen, were closed by legislative decree in 1774 for two primary reasons: concerns that performances would distract Americans from the revolution at hand, and for fear that the theatre, as a supposed site of excess, would waste valuable resources needed in time of war. In The Group, Warren takes aim at the British men occupying Boston and she charges them with these very sins. Simple, for instance, confesses that his "paternal acres are eat up," his "patrimony spent," while Hateall admits that he married his wife merely to "secure her dower" (44-45). Beau Trumps connects excess, the playhouse, and Warren's play even more explicitly:

That's right, Monsieur,

There's nought on earth that has such tempting charms

As rank and show and pomp and glittering dress,

Save the dear counters at beloved quadrille.

Viner, unsoiled, and Littleton may sleep,

And Coke lie moldering on the dusty shelf,

If I by shuffling draw some lucky card

That wins the livres or lucrative place. (36-7)

Here "rank and show and pomp and glittering dress" are used to mark colonial rule as performance and the "lucrative place," according to Amelia Howe Kritzer's footnote "implies that the Tories awarded government posts to the winners of card games," games which, as we have seen, were taking place within the early American theatre (37). Making this kind of critique from the stage would have been difficult, then, not just because the playhouse had been shuttered, but also because the theatre was itself aligned with British excess in the minds of 
many Americans. Better to motion on the page towards the political performances of the morally bankrupt Tories than to bring such a critique to the playhouse, a site that was so often accused of its own wasteful excess.

For all the ways that Warren manipulated the idea of the theatre in her closet drama, she found herself unprepared for the ways her text was manipulated once circulating in the public sphere. The publication history of Warren's The Adulateur (1772), in particular, highlights the downside of the ideal Habermasian public sphere, as the text was divorced from its author and, once in circulation, took on a life of its own. Sketches of the ostensibly unfinished play were first published anonymously in Boston newspapers alongside editorials and political news, an appropriate placement given the play's castigation of the Loyalist Thomas Hutchinson (here called Rapatio). In 1773, and unbeknownst to Warren, the dramatic sketches were taken up by an unknown writer who "added to them, and published the five-act play as a pamphlet" retitled The Adulateur: A Tragedy, As it is now acted in Upper Servia (Sarkela 551). ${ }^{12}$ Warren referred to these additions as a "plagiary," and so it comes as little surprise that late in her life, she and her son, James Warren, Jr. revised and circulated three of her plays (of which The Adulateur was one) in manuscript form.

If "the republican ideology of print elevated the values of generality over those of the personal," Warren's reaction to the plagiarism of The Adulateur suggests that she feared her already marginalized voice and message might be lost when her work was taken up by another (Warner, Letters, 108). It makes a great deal of sense that an early American woman would resist disembodiment in print. A prodigious letter-writer, Warren conversed with such powerful figures as John and Abigail Adams, and while Alexander Hamilton saw in Warren evidence that "female genius in the United States has outstripped the male," her role in the republic was, as we have 
seen, nonetheless limited by her gender (qtd. in Chernow 363).

As a result, there was simply more at stake for Warren than there was for a writer like Benjamin Franklin, who went on to find many other ways to wield political power beyond the works of his nom de plume, Silence Dogood. "An average upper class white woman in Boston," Jenny Kokai writes, "had servants to free her from some of the domestic burdens but her days were occupied with other tasks she understood as her job: social activities, charities, meetings, shopping, and other activities that were considered an essential part of participating in 'polite' society" (9-10). Further, while Warren was able to converse on wide-ranging political and cultural topics with leading figures of her day, these conversations took place either in letters sent from home or in person at her home where she would have been expected to "entertain" her male guests and not necessarily to engage them in anything more than polite conversation. Since Warren and her husband owned a home "large enough to host visiting dignitaries," Warren would have met such dignitaries at her farm house in Plymouth at a remove from the political circles of Boston (Kokai 11). We know, for instance, that Warren rarely journeyed to Boston, and so she relied on her connections to writers like Judith Sargent Murray who had greater “access to those with money and social connections" (Kokai 16-17). In short, Warren's domestic obligations as an upper class wife of a well-known politician brought her into contact with many of most powerful public figures of her day, but these obligations also severely constrained her geographic mobility.

Warren's reaction to the "plagiary" stands to change our reading of her subsequent closet drama, The Group. Once again, Warren found the motivation for her play in a piece of legislation that she found odious, the Massachusetts Regulatory Act, which gave Thomas Hutchinson, the Massachusetts Royal Governor, nearly limitless powers. The Group offers a 
thinly veiled depiction of Hutchinson and the Tory men who make up his political cabinet as they negotiate with one another about how best to rule over the colonies. ${ }^{13}$ Act one begins after Hutchinson/Rapatio has fled back to England, and so the play consists of conversations among the remaining members of the Mandamus Council, all of whom are named either through allusion (i.e. General Thomas Gage as "Sylla") or through pejorative descriptors (i.e. Nathaniel Ray Thomas as "Simple"). In either case, part of the fun for readers would have been matching contemporaneous political figures with their fictionalized counterparts in the play. Throughout, the Mandamus Councillors lay bare their true intentions with regard to the Patriots ("To spread distress o'er this devoted people") and their base motives for continuing the fight without their Governor ("I sold my country for a splendid bribe") (32).

The Group may not have a definable plot but it does gesture towards a radical reading of domestic spaces as significant sites of public engagement. With the theatre in Boston literally displaced by Massachusetts anti-theatrical law, Warren took it upon herself to imagine the home, rather than the public stage of the tavern or city hall as a place of political revolution. For instance, The Group makes much of allusions strewn throughout the play, allusions that are often used (by Warren scholars) to argue that a great deal of the play's meaning would have been lost on audiences if the play were performed. We might turn this analysis on its head, though, and see the play not as un-stageable, but rather gaining something from not being intended for the stage. For example, act two scene one begins with a description of a room furnished with a "small cabinet" containing nine well-known texts, such as Hutchinson's History and Hobbes's Leviathan (34-5). Such small but, in Warren's eyes, important details would be lost on theatregoers due to proximity and poor lighting, but readers could make much of allusions to a text like Leviathan, which was adopted as a foundational tract of the Loyalist movement. These textual 
allusions also signal Warren's interest in the public-ness of the home, as Warren links these texts to the domestic spaces that would house such "small cabinet[s]," and the seemingly private rooms where such reading took place.

At the same time, Warren balances this intertextuality with a familiar emphasis on the idea of the stage, though in light of The Adulateur's plagiarism, this emphasis takes on added meaning. Indeed, the first bit of text that follows the dramatis personae in The Group is a description of the "court sycophants, hungry harpies, and unprincipled danglers, collected from the neighboring villages, hovering over the stage [emphasis mine] in the shape of locusts" (30). Here Warren uses the metaphorical stage as a dividing line between Patriot readers and Tory actors. In doing so, she marks Tory leaders as performers, such as when Beau Trumps (Daniel Leonard) describes his beginning in politics as entering "on the public stage," and refers to his past as the period "ere we trod the stage" $(37,39)$.

Warren is interested in more than simply denouncing Tory leaders as actors who lack the genuine motivations of the Patriots. The actual stage, at its core, puts bodies on display, and so for Warren the metaphor of the stage augmented the ideal Habermasian public sphere. On the one hand, the imagined stage obscures the writer of closet drama, but on the other, using the public-as-stage metaphor re-embodies the disembodied public sphere, which privileged circulating texts over interested writers. Warren thus keeps these politicians in view, embodied, so that audiences can see them at their worst and she prevents them from hiding behind anonymous or pseudonymous publications.

When The Group overflows with violent speech, as it often does, Warren reminds us that pens may wage their own kind of war, but the resulting casualties are the result of violence against bodies. Collateralis complains that even in the face of oppression the Patriots are "more 
resolved than ever," "though Britannia sends her legions o'er, / To plant her daggers in her children's breast" (40-41). Dupe echoes these statements near the end of the play, admitting that the Patriots "fight for freedom, while we stab the breast / Of every man who is her friend professed" (52). The violent language of Tory leaders reminds readers of their inherent villainy, but it also emphasizes the embodiment of this villainy. This was due in large part to the deictic function discussed earlier, with its insistence on pointing away from the author and towards characters on the imagined stage. For Mercy Otis Warren, this deictic function points towards those she found worthy of blame in her political closet dramas-namely the Loyalists who so often found themselves on the receiving end of Warren's dramatic attacks.

Not content to point towards the Loyalists as villains, in the final scene of The Group Warren brings a Patriot onto the figurative stage. In this scene all the players exit, and "as they pass off the stage, the curtain draws up and discovers to the audience a LADY nearly connected with one of the principal actors in the group, reclined in an adjoining alcove, who in mournful accents accosts them" (52). The intrusion of this female voice in an otherwise all-male play is significant, not least because Warren invites us to read this character as a stand-in for herself. The Lady seems to be of the leisured class since we are to envision her "reclined in an adjoining alcove," a domestic space where we might easily imagine Warren writing The Group. Additionally, the Lady's "mournful accents" are reminiscent of many of the elegiac letters that Warren wrote over her lifetime concerning the revolution and its aftermath. The fact that the Lady was discovered "nearly connected with one of the principal actors" highlights the privileged place of the writer who, in this case, is privy to the private proceedings of the court as she listens from just off-stage. One may be an actor - in the most pejorative sense- but it is the Patriot woman writer who controls the script from the wings. 
Nancy Fraser's feminist critique of the Habermasian public sphere seems remarkably similar to Warren's project as I've outlined it here. "A tenable conception of the public sphere," writes Fraser, "would countenance not the exclusion, but the inclusion, of interests and issues that bourgeois masculinist ideology labels 'private' and treats as admissible" (77). We would be hard-pressed to locate a more fitting description of how Warren's closet drama utilized the theatre: the writer speaks from a domestic space to an audience of the figurative stage, an image that calls into question the private nature of the former and the public standing of the latter. ${ }^{14}$ Instead, Warren theorizes an intermediary space where a private document — a closet dramawritten not by a politician but by a politician's wife, can participate in a very public, highly politicized conversation.

This intermediary space insists on gendered embodiment. In response to The Adulateur's plagiarism, in The Group Warren uses the deictic function and the stage's insistence on gendered embodiments to shape the stage — here read as a metaphor for the republic — as a place where the female body can't be divorced from her writing, where the domestic is political, and thus where the terms "private" and "public" aren't so easily defined in opposition to one another. In defining a public as "poetic world-making," Michael Warner tells us that "public discourse says not only: 'Let a public exist,' but: 'Let it have this character, speak this way, see the world in this way'” ("Publics" 82). For Warren, this process must be embodied so as to remind the reader how she (and the emphasis on gender is key) sees the world.

Once the Governor's men have been ushered off the imagined stage, the Lady remains behind where she delivers a soliloquy that looks to the future of the republic by, once again, pairing the embodied with the textual. The Lady describes the "painful scenes" that "hover over the morn" after a bloody battle leads to Patriot casualties: 
What painful scenes are hovering o'er the morn,

When spring again invigorates the lawn!

Instead of the gay landscape's beauteous dies,

Must the stained field salute our weeping eyes,

Must the green turf and all the mournful glades,

Drenched in the stream, absorb their dewy heads;

Whilst the tall oak and quivering willow bends,

To make a covert for their country's friends

Denied a grave amid the hurrying scene

Of routed armies scouring o'er the plain,

Till British troops shall to Columbia yield,

And freedom's sons are masters of the field!

Then o'er the purpled plain the victors tread,

Among the slain to seek each patriot dead,

While freedom weeps that virtue could not save,

But conquering heroes must enrich the grave.

An adamantine monument they rear,

With this inscription: Virtue's sons lie here! (53)

Warren substitutes the battlefield for the stage ("painful scenes") in a closing epigraph that grounds her satire in the material reality of the written word. Put differently, according to Warren's Lady, historical memory is best conveyed through a pairing of the indestructible ("adamantine") monument and, in Warren's articulation, the female writer as an embodiment of American Revolution. That such an epigraph was disseminated in a work of closet drama should 
remind us that the genre was hardly fleeting, far from private, and even if produced in a domestic setting, it stood to engage the public in the Patriot cause.

I began this chapter with the enduring image of John Adams undertaking a risky journey at a delicate age, all to write Mercy Otis Warren's name in a copy of The Group. I then posed a question that is worth revisiting: What did Adams fear would be lost to history if The Group was committed to posterity as an anonymously authored political drama? Though we can't know or even speculate on Adams' motivations, we can take note of what we have gained by his action. Warren's texts helps us articulate the complexity of dramatic print practices in Boston and beyond, and these works also force us to reassess the supposed links between feminine domesticity and closet drama. Finally, we are reminded that Warren used the stage to imagine a space of gendered embodiment that resists disembodiment, the governing fiction of republican letters. 
Notes

${ }^{1}$ This scholarly conversation has been immensely generative, yielding Cultural Narratives: Textuality and Performance in American Culture before 1900 (2010), a collection of essays that "imagine a modern history of the manuscript and the spoken word without privileging the printing press, while still affording it a transformative role in the evolution of texts" (Sloat 3).

${ }^{2}$ Of course, Warren is not the only writer who utilized closet drama in early America. Much remains to be written about a work like Crevecoeur's Landscapes, which offers “An American Perspective Divided into Six Landscapes.” Crevecoeur self-consciously marks this work as closeted, as it is his "simple wish...to present you with some of the primary elements and original component parts in their native appearance ere they were artfully gathered, united, new-modeled and polished by our modern legislators" (424).

${ }^{3}$ It should be noted that Warner disagrees with Fraser's own definition of what she calls “subaltern counterpublics." Warner advocates for the term "counterpublics," which are publics "in a stronger sense than simply comprising subalterns with a reform program" ("Publics" 86).

${ }^{4}$ Closet drama's tendency to undercut notions of authorial intent plays a related part. We might argue that this shouldn't be a problem for recent scholars interested in revising or expanding the canon. Take David Shields's study of British American belles lettres — works that share a great deal in common with dramatic texts from the period - in which he makes a strong case for a literary history that can be "written without a chronology of classics, without fixing upon master texts" (xxv). But even in Shields' insistence on inclusivity, he is careful to outline the authorial intent that stands behind these polite letters. "These writings," according to Shields, "did not insist that posterity attend to their message," as they were in fact 
"designed not to seek eternal regard" (xxv). If it is indeed true that "the canon is a concept that agrees with the academic need to compartmentalize," one might argue that canonical revisions have supplemented the early American canon with texts both intended for posterity and texts that are recoverable even if not meant to last (Straub 107). One "problem" with closet drama, and one reason that it remains an under-studied field of inquiry, lies in its inability to fit neatly within even these expanded canonical compartments.

${ }^{5}$ This ban was re-issued in 1778 .

${ }^{6}$ It is important to note, as Marta Straznicky does, that "the bodies of playgoers at the private theatres were no more secure than at the public venues (witness the numerous references to pickpocketing, prostitution and sexual touching" (9). In short, as performances during the Interregnum shifted from public to private venues, "closed theatres" failed to "secure...[the] boundaries and...protect the integrity of the theatre-going subject" (8).

${ }^{7}$ The language in the Continental Congress's 1774 ban on theatrical entertainment is decidedly focused on the financial waste that accrues from such performances rather than the political hazard that might result from attending a performance by men of the British Army and Navy. Thus the legislative document reads: "We will, in our several stations, encourage frugality, economy, and industry, and promote agriculture, arts and manufactures of this country, especially that of wool; and will discountenance and discourage every species of extravagance and dissipation, especially all horse-racing, and all kinds of gaming, cock fighting, exhibition of shews, plays, and other expensive diversions and entertainments.” (qtd. in Bryan 31)

${ }^{8}$ If anything, the ban on theatre helped politicize the campus performances at schools like Harvard, where propaganda plays were produced to stage significant moments from the 
Revolutionary War (Shafer 133).

${ }^{9}$ See Bruce McConachie's Melodramatic Formations, which notes that in the 1820 s the lights were kept on in theatres so that spectators could observe each other in addition to the players on the stage (14).

${ }^{10}$ Jurgen Habermas describes the evolution to a public theatre which is made manifest in the ways that the state tried to legislate these newly admitted patrons. For instance, as the theatre became more accessible to the bourgeois public, "Parisian police ordinances...were issued to combat the noise and fighting and, indeed, killing" on the main floor of the playhouse (38).

${ }^{11}$ Marcy North argues that the rise in print culture in England "did not replace medieval anonymity with naming" but rather "opened up new possibilities for anonymity, some that had connections to earlier scribal conventions, and others that developed as direct responses to the conditions and capacity to print” (29).

12 This plagiarized version of Warren's play also contained an expanded cast of characters and while Warren's original version "focuses on the political climate of 1772," the new version was "altered in theme to the Bloody Massacre of March 5, 1770" (Richards, Mercy, 86; Hutcheson 384).

${ }^{13}$ Warren's father, Colonel James Otis, was involved in a political rivalry with Hutchinson, as both vied for the position on the superior court. Hutchinson was ultimately appointed as chief justice (Richards, Mercy, 8-9).

${ }^{14}$ There is also an ambiguity in these stage directions. Who does the Lady accost? On the one hand, it seems possible that Warren's stand-in directs her final lines to the Tory leaders who have played their parts throughout the play. On the other hand, it seems 
equally possible that the Lady directs her mix of melancholy and anger at the audience, in this case readers of the closet drama. 


\section{Chapter Two: Pocahontas Plays, Melodrama, and the Displacement of History Onstage}

While early American playwrights used the dramatic form to engage in very public, political debates, the stage became an alternative site for cultural, social, and political commentary in the new nation. Theatre patrons in the late-eighteenth century could see plays like Royall Tyler's The Contrast (1787), which balanced British theatrical tradition with a desire to define a distinctly American theatre, no doubt contributing to that play's success. ${ }^{1}$ Later plays, such as William Henry Smith's The Drunkard (1844) and George Aiken's adaptation of Uncle Tom's Cabin (1852), rode a tide of topicality by responding to calls for temperance reform and abolition, respectively, in the U.S. In short, Americans certainly engaged one another through textual avenues such as novels and belles lettres, but the playhouse functioned as a more popular, more accessible testing ground for determining what America could or should become.

Engaging with current events, though, could be detrimental to a play's commercial success. Take, for instance, William Dunlap's André (1798), which dramatized the capture of the British major John André who was put on trial for espionage and ultimately executed on the orders of General George Washington. In his History of the American Theatre (1832) Dunlap locates the offending scene within Act III scene I: "The play was received with warm applause, until Mr. Cooper, in the character of a young American officer, who had been treated as a brother by André, when a prisoner with the British, in his zeal and gratitude, having pleaded for the life of the spy in vain, tears the American cockade from his casque, and throws it from him" (226). The hint of anti-American sentiment in this gesture fed broader concerns that the nation's greatest hero, and first president, was being cast in the off-stage role of villain, with John André assuming the role of heroic martyr. ${ }^{2}$ André's refusal to draw clear distinctions between British and American, right and wrong, may have enabled Dunlap to dramatize the problems inherent in 
such clear-cut distinctions, but it also contributed to the play's unsuccessful and short run. In Dunlap's own estimation, his play failed to gain commercial traction due to its "most unfortunate subject for the stage, at a period so near the time of the event dramatized" (History 225). By pinpointing topicality as the reason for André's commercial failure, Dunlap makes the provocative, if implicit, claim that early Americans were more comfortable with dramatic performances that offered plot and setting at some historical remove.

To some degree, a similar assertion could be made about a variety of literary forms in the wake of the American Revolution. Ben Franklin's Autobiography, for instance, is noticeably silent regarding the war with Great Britain, an omission that leads Christopher Looby to argue that the relative paucity of literary works addressing the war head-on illustrates that "revolution is a process...[which] resists representation" (124). Others, such as Nina Baym, find that relatively few historical plays were produced during the early national period for reasons of literary taste in genre, as she argues that American writers were more apt to ape the historical fiction of Sir Walter Scott than the historical plays of Shakespeare (203).

Yet the early American stage did play a key role in creating a narrative of historical progress in the new nation, as a site where a newly assembled populace went to be reminded of a common, cohesive, and unified history. As Jeffrey Richards argues, early Americans relied on the metaphor of the world stage "not simply as a rhetorical nicety but often as a trope deeply reflective of America's place — and the spatial meaning is intended—in history" (Richards, Theater, xviii). If their reliance on the theatrum mundi trope articulated the conceptual intersection between theatrical space and historical time, it stands to reason that early Americans expected to find their place as Americans reflected on the literal stage.

To meet audience expectations, and with the Revolutionary War seemingly too close for 
comfort, some playwrights turned their gaze to an earlier period in a quasi-historical search for American origins. This search landed, quite tellingly, on a narrative made more of myth than history in the story of Pocahontas and the settling of Virginia, led by that American Adam, Captain John Smith. In addition to the many novelistic and historical treatments of Pocahontas, there were at least six Pocahontas plays (and likely a host of less formal performances) in circulation between 1808 and 1848, and these plays ranged from those ostensibly committed to historicity, to dramas that were comfortable straying further from the historical record. ${ }^{3}$

In this chapter I will examine two plays spanning these four decades: James Nelson Barker's The Indian Princess (1808) and Charlotte Mary Sanford Barnes' The Forest Princess (1848). I have chosen to focus on these two plays primarily because they are so distinct from one another, at opposite ends of the spectrum with regards to a belief in the possibilities of putting history onstage. As the first professional play based on the Pocahontas narrative, Barker's drama stages the history of America as the transformation of American space into a world stage. The Indian Princess looks back on the conquest of America through a revisionist lens, where the "successful" colonization of the new land is taken for granted, and conflict between Native Americans and Europeans is secondary to Shakespearean comedy onstage. Barker's play fuses history and myth, offering a teleological view of the conquering of American space by Europeans in an entertaining package that tapped into the burgeoning demand for sensational melodrama.

It is only later in Barnes' play that the Pocahontas narrative would be reworked with the explicit aim of recounting Pocahontas' life in a more historically accurate way. ${ }^{4}$ In her introduction to the play, Barnes laments "the lack of intelligible chronicles [which] has left the early history of the red men imperfect," and despite the often sensational portrayals of 
Pocahontas onstage, she attests that "the various historians and colonists concur in the assertion that but for the benefactions of Pocahontas, Virginia would have been lost to England" (322). Barnes hopes to achieve a more faithful rendition of the Pocahontas story by disrupting a unified American mythology through trans-Atlantic encounter and a more complex portrayal of Pocahontas. Indeed, as one scholar notes, The Forest Princess "clearly subverts popular Indian plays of the day by supplying Pocahontas with a voice, granting her political status, and allowing her to reject colonial domination" (Jaroff 483). As we will see, Barnes' interest in rescuing Pocahontas from the realm of mythology likely stemmed from a larger cultural movement, as women increasingly became the bearers of historical memory in the new republic. Yet the play's anxious footnotes and overt attempts to uphold historicity show little confidence that the stage could bring her lofty goals to fruition.

My interest lies not only in describing the respective playwrights' confidence (or lack thereof) in placing history onstage, but also in determining what it means that two writers working from the same source text, Smith's General Historie, could reach such disparate conclusions. After all, as Jeffrey Richards has argued so persuasively, Smith's work employs a "theatrical vision" that "transforms...the unconquered spaces of North America...into stages of history" (Theater 85). If the source text for subsequent Pocahontas plays theorizes the world as a stage, then, one is left wondering why the stage, in turn, can't be a site of history. Whereas Barker succeeds in placing history onstage (insofar as the playwright and audience are comfortable with Smith's brand of simplistic, providential history), I will suggest that Barnes' more ambiguous understanding of American place-making can be interpreted as a related anxiety about transforming nation-building discourse into theatrical staging.

We might, then, read The Forest Princess not as a failure, but rather as documentary 
evidence of an inherent conflict between dramatic aspirations to supplement the historical record and the melodramatic mode, which evolved to become increasingly at odds with attempts to place history onstage. Noting the tension between melodrama and history has far-reaching implications with regard to the intersection of cultural memory and national identity. National narratives, according to Homi Bhabha, depend on the collective act of forgetting, which occurs through "the construction of a discourse on society that performs the problematic totalization of the national will" (311). Rather than providing a site for collective memory, then, the early American stage (and, more specifically, Pocahontas plays) tended to reinforce the stage as a site of collective forgetting, where the Pocahontas narrative was mistranslated to uphold "the assumed inevitability of European settlement in the Americas" (Brickhouse 942). Despite her attempts to rescue Pocahontas and her people from erasure, Barnes' play ultimately succumbs to the phenomenology of the melodramatic stage with its "allegorical scenes and figures" that highlight the unbridgeable distance between the national present and the nation's contested past (Barnes 367).

Staging John Smith's Generall Historie in Barker's The Indian Princess

As a work that bills itself as recorded fact, John Smith's Generall Historie of Virginia, New England \& The Summer Isles (1624) contains as much posturing as record-keeping, an opus to one man as much as one colony. It is also, for all its length and breadth, a work of first-hand memory rather than historical research. In some instances Smith reminds readers of its fallibility as history, alerting us to his larger purpose by selling the idea of Virginia to potential investors. "And this is as much as my memory can call to minde worthy of note," Smith writes, "which I have purposely collected, to satisfie my friends of the true worth and qualitie of Virginia" (80). 
These admissions, however, don't discount its influence on later histories of the region, particularly Robert Beverley's History and Present State of Virginia (1705) and William Stith's History of the First Discovery and Settlement of Virginia (1747), both of which have been read as early re-workings of Smith's narrative (Craven 481-2). Nor has Smith faded from popular consciousness. Disney’s 1995 animated film exposed a new generation to the Pocahontas narrative through an embellished adaptation that finds its roots in Smith's seminal account of Native American encounter and conquest.

In fact, Smith's narrative performance was itself a kind of re-telling. A "Pocahontas Perplex" existed through the "powerfully symbolic Indian woman, as Queen and Princess," dating back at least to 1575 when she came to represent the New World in the "Four Continents" illustrations, which depicted a male and female Indian as representative of the Americas (Green 701-2). The Pocahontas narrative would be largely set aside in the seventeenth and early eighteenth centuries, but the story, not coincidentally, popped up once again in the years following the Revolutionary War. Though it is unlikely that Smith's text was readily available in the late eighteenth-century, by the early nineteenth-century, an increased demand for The General Historie spiked due to the prevalence of Pocahontas narratives that began to crop up in other texts at this time, including a host of engravings from this period (Tilton $38-9) .^{5}$ An extensive review of Smith's General Historie published in 1808 in The Boston Review suggests both that Smith's text piggybacked on these other popular narratives and was more widely available for readers by the time that Barker's play hit the stage ("Retrospective" 455).

By emphasizing the spectacle of the Jamestown experiment and in casting himself as the hero of his own tale, Smith's text offers as much a performance of American origins as a history of its beginning. ${ }^{6}$ Thus he recounts a number of performances between colonists and natives, and 
he often does so while writing about himself in the third person. After being captured by "salvages," Smith is "conducted to a long house, where thirtie or fortie tall fellowes did guard him, and ere long more bread and venison was brought him then would have served twentie men" (98). Smith is later put on display for Powhatan, where "more than two hundred of those grim Courtiers stood wondering at him, as he had been a monster" (101). But before Powhatan's men can "beat out his [Smith's] braines, Pocahontas the Kings dearest daughter, when no intreaty could prevaile, got his head in her armes, and laid her owne upon his to save him from death" (101). Scholars have long suggested that Smith either fabricated this entire exchange or was unaware of his own role within a larger welcoming ritual for a cultural outsider. ${ }^{7}$ Regardless of which claim we find most compelling, Smith's Pocahontas narrative is born of an embedded narration of performance within a larger text that is itself interested in performing the "origins" of a new land.

Less often noted are the ways that The Generall Historie itself resembles a dramatic text. In the opening section, which details the voyage to Virginia, Smith concludes with a list of the players in this drama of discovery:

The performers [emphasis mine] of this voyage were these following.

$$
\left.\begin{array}{l}
\text { Philip Amadas. } \\
\text { Arthur Barlow. }
\end{array}\right\} \text { Captaines }
$$

$\left.\begin{array}{ll}\text { William Grenvill. } & \begin{array}{l}\text { Benjamin Wood. } \\ \text { John Wood }\end{array} \\ \text { James Browewich. } & \begin{array}{l}\text { Nicholas Peryman } \\ \text { John Hewes }\end{array}\end{array}\right\} \quad$ Of the Companie.

This visual outline enables Smith to accomplish two aims rather efficiently: first, it demarcates a clear hierarchy both through labeling and through the spatial aspects on the page, where the "Captaines" rise above the rest "Of the Companie." Second, this typesetting resembles the 
traditional dramatis personae found at the beginning of a published play, suggesting the extent to which these men become "performers" not just on the historical stage but also as actors under Smith's narrative control. Nor is this an isolated occurrence in the Generall Historie. Smith uses this typographical feature throughout, such as when he organizes the "names of them that were the first planters" of Virginia beneath the headings of Councel, Gent[lemen], Carpenters, and Labourers, a division of labor which, unsurprisingly, places Smith within the first category, above the rest (90-1). Jeffrey Richards traces Smith's “theatrical vision" of America, as both author and actor "on the martial stage of Virginia," offering the "Prospero of Virginia" as a telling example of the early American tendency to adopt the metaphor of the theatre as a descriptive construct for colonial life (85-9). While the trope of theatrum mundi would be more widely used as a rhetorically effective metaphor for American life in Puritan America, Smith's text uses this "metaphor for history itself" to "convert private experience into public history" both through content and form (Richards, Theater xii-xiii, 60).

James Nelson Barker converted the Pocahontas narrative from page to stage in The Indian Princess, which was first performed at Philadelphia's Chestnut Street Theatre on April 6, 1808. ${ }^{8}$ One reason that it took so long for Pocahontas to enter the playhouse-especially when compared to the illustrations that had been in circulation since the late sixteenth century-lies in the relative paucity of formal theatrical performance in the early nation due to the Continental Congress's 1774 wartime ban on theater, which was reissued in $1778 .{ }^{9}$ Performances weren't snuffed out completely, as Jason Shafer finds that new venues sprung up, such as on "colonial campuses [which acted] as incubators of both early American performance culture and Revolutionary political sentiment" through the production of propaganda pieces (107-8). Still, it would be wrong to argue that these formal decrees didn't curtail dramatic performance by 
professional actors. It was only after these statutes were lifted that those actors cast out in the 1770s returned to "a new political reality around which they had to tread lightly to ensure that audiences would not denounce them as Tories or British sympathizers" (Richards, "Politics" 203). ${ }^{10}$ By the time that Barker's play hit the boards, major American cities were inundated with playhouse performances, albeit mostly based on British dramas.

It was into this environment that Barker re-introduced the American public to a story they could adopt as their own. Yet because the Pocohontas narrative has become so ingrained in our national consciousness, it is easy to lose sight of the fact that The Indian Princess skillfully adapts a story of colonial origins - Smith's general history of Virginia —into a national history. Barker's play set off a wave of historical plays, as an unsettled political climate combined with an increasing demand for popular entertainment with a historical slant. ${ }^{11}$ Indeed, the year of The Indian Princess's first production, 1808 , found the nation in a state of palpable transition. Just a year before, President Jefferson had championed the Embargo Act, a piece of legislation that moved the U.S. closer towards the War of 1812, even as it was meant to uphold peace in a nation that some feared could not withstand another struggle with England. To make matters more complicated, 1808 was also the year that Jefferson ceded his position as commander-in-chief, passing the baton to James Madison who was perhaps no less capable but certainly inspired less confidence in his constituents. ${ }^{12}$ Ironically, it was at the very moment that the U.S. began to perform republicanism (voter participation jumped from 20 to 80 percent from 1790 to 1810) that the nation seemed least sure about what it wanted to be, with conflicts between Federalists and Republicans arising regularly (Wood 302).

An itinerant population and new geographic realities contributed to this political instability. New York gained 374,000 people, 147 new towns, and 15 counties between 1800 and 
1810 , and during the same period Ohio's population grew from 45,000 to 230,000 (Wood 316). What bearing, though, do these current events have on Barker's play? Herbert Lindenberger has argued that historical drama allows the dramatist to "seek out an era whose essential conflicts seemed to point forward...to anticipate those later stages of the historical process" to better resonate with audiences (9). On at least one level, then, The Indian Princess re-appropriated colonial "victory" at a moment when the very definition of America (and Americans) was being negotiated.

Barker's play tells the story of white settlement by melding melodrama with Shakespearean comedy. As an "operatic melo-drame," The Indian Princess should be distinguished from later iterations of melodrama, with the former springing from French plays that combined music and dialogue, in the vein of popular plays by Pixerecourt. The plot follows Captain Smith and his band of merry men as they come ashore in edenic Virginia and set about negotiating with the natives. With its focus on populating the newly "discovered" land, the bulk of the play pairs adventurous men with the women who will bear the fruit of the colony's labor. The play begins with Pocahontas betrothed to the prince Miami in an arranged marriage that will bring Pocahontas's father political power, but she must ultimately be paired with Rolfe, who transforms from a model of pessimism to a hopeless romantic infatuated with the young woman. Though he early complains of the "whimsies and caprice" of the fairer sex "so variant and wild," he foreshadows his later marriage to the young princess, for, "Rather than wed a European dame, / I'd take a squaw o' the woods, and get papooses" (130). When, at the end of the play, Pocahontas has chosen Rolfe over Miami, other pairings become possible, such as Robin and Pocahontas' attendant, Nima. Running beneath these domestic pairings is a union of more lasting cultural importance. Powhatan sees no choice but to "massacre my friends," setting the stage for 
Pocahontas to step in once more to save Smith and his patrons from a violent attack, this time at the hands of Miami. By choosing the European newcomers, Pocahontas rejects Powhatan, and the latter experiences a "shame [that] ties the tongue" (162). ${ }^{13}$

Critical treatments of The Indian Princess tend to focus on issues of race within the play. For instance, Susan Scheckel argues that Barker skillfully avoids Indian removal politics of the time by making Pocahontas the melodramatic heroine rather than depicting Smith or Rolfe as melodramatic heroes, for if the latter were true "the play would have represented all too realistically Euro-American violence at the center of the national drama" (50). ${ }^{14}$ Jeffrey Richards similarly locates the play as a reaction to national expansion, noting that the "assimilation of the children of Powhatan" would have garnered support from Americans in the wake of the Louisiana Purchase ("Politics" 215). As a shrewd playwright who found a way to use national politics for personal gain, it does seem likely that Barker was pandering to audiences with The Indian Princess, especially given Barker's previous dramatic effort, Tears and Smiles (1806), a work that was considered too British and thus critically panned and commercially avoided (Bak 182-3). It is perhaps for this reason that Barker includes a lengthy diatribe against such critics in the preface to The Indian Princess:

In sending it to the press I am perfectly apprized of the probability that it goes only to add one more to the list of those unfortunate children of the American drama, who, in the brief space that lies between their birth and death, are doomed to wander, without house or home, unknown and unregarded, or who, if heeded at all, are only picked up by some critic beadle to receive the usual treatment of vagrants. (115)

Portraying the early American theatre as an orphaned institution enabled Barker, first, to paint 
the theatre as only in its infancy with the promise of growing over time, and second, to hold out the hope of sustained freedom from the mother land, a subtle but calculated jab at British culture that further distinguished this play from Barker's previous commercial flop. Not incidentally, Barker's preface also personifies the theatre as "unfortunate children" who are displaced from their homes and denigrated as "vagrants," a description that suggests the connection between the displacement at the heart of the early nation, its people, and the theatre.

The Indian Princess, nonetheless, tells the story of American origins to an audience that, by their very presence in the theatre, attest to the "success" of John Smith and his band of Jamestown settlers. Yet there is plenty of evidence that Barker needed to perform a number of dramatic sleights of hand to attract paying customers while maintaining at least some claims to historicity. Barker refuses to pin down a precise chronology in the play, choosing instead to loosely set the play in 1607-8, "thus keeping the ties to Britain at a remove that would be unlikely to exercise the members of the audience whose sympathies ran hotly against the former mother country" (Richards, "Politics," 215). Barker glosses over most evidence of the colony's - and by tenuous extension, the nation's - contested past in the play proper, but signs of this tension are evident in the play's extra-dramatic text. For instance, in the hierarchy of the play's dramatis personae, Barker lists the "Europeans" above the "Virginians" where the latter describes the Native American characters that grace the stage. Separating the cast of characters along these lines places the early Americans on uncertain footing. Unable to fully identify with either the play's European or Native American characters, readers are asked (in ways that audiences in the theatre were not) to more fully conceive of the historical distance between the American origins presented in The Indian Princess and the present of 1808, with the forced assimilationist stance of Jeffersonian politics and with the U.S. nearing a second war with Great 
Britain.

In an effort to mitigate any resulting audience anxieties which may have accompanied this gap in the play's historical record, Barker consistently reminds his viewers of the outcome of Smith's conquest, the ultimate liberation and superiority of America. In the opening song of Act I scene 1, Barker alludes to Shakespeare's The Tempest, assuring listeners that "The tempest's roar is heard no more,.../ For past are the perils of the blust'ring sea" (118). As the hero capable of making grand pronouncements, Smith encourages his fellow adventurers by pointing toward their future place in history, a place already ingrained in the national consciousness of those in attendance:

Now, gallant cavalier adventurers,

On this our landing spot we'll rear a town

Shall bear our good king's name to after-time,

And yours along with it; for ye are men

Well worth the handing down; whose paged names

Will not disgrace posterity to read. (119)

Here Barker signals a conflation of readers and theatre-goers, for Smith's exploits may be read about in his history, but in this case those "paged names" of the Jamestown settlers end up on the stage, not the page. Smith's opening soliloquy similarly assures his shipwrecked brethren of their place in history at the same time that he engages in a bit of metadrama at the end of his speech:

Gallant gentlemen,

We have a noble stage, on which to act

A noble drama; let us sustain

Our several parts with credit and with honour. 
Now, sturdy comrades, cheerly to our tasks! (119)

Where Smith earlier seems torn between seeing history as textual or performed, here he is more forceful in claiming that the stage can grant the "actors" of this "noble drama" a place within public memory as a band of men (and, to a lesser extent, women), all of whom can afford to sing cheerful songs with the outcome of the colony's founding already decided. Barker thus theorizes the stage as a theatron — a space for seeing — for a nation not in the process of transforming, but rather as a space already changed by the European characters who, by their very presence, transform America into a stage for the world to see.

Barker pairs this Euro-centric view of history with an emphasis on predestination to make the tasks of nation building entertaining for audiences that knew all too well the growing pains of seceding and starting anew. Thus the storm that blows Smith's troupe ashore "arose propitious" driving these men and women "to happiest destinies" (118-199). Another recurrent means of invoking predestination comes in the form of metadramatic dialogue meant to conflate actors in this drama and the actors of historical record. When Robin asks, "In this same drama that our captain spoke of, you and I act parts, do we not," Barker reminds us that the events onstage are scripted, and as such the ending has been written (121). In order to further emphasize American exceptionalism, Barker highlights Smith's rejection of British culture, which likely would have resounded with audiences. "Let our dull, sluggish, countrymen at home," Smith snarls, "Still creep around their little isle of fogs, / Drink its dank vapours, and then hang themselves" (119). By castigating the "base atoms in the mass of population / That rots in stagnant Europe," Smith offers contrasting views of America as both a wide open tabula rasa awaiting inscription and a place where men have (always, already) risen above the level of base humanity (119). With British culture safely described as over-matured to the point of petrification, viewers could 
reflect on the established and distinctly American culture that seemed, if not already achieved, on the horizon, and they could view Smith as an early patriot for the American cause.

Even as Barker chose subject matter that fed the nation's desire for a coherent narrative of origins, he was savvy enough to retain a familiar dramatic structure that drew heavily on British dramatic forms. For instance, Barker's decision to partner with composer John Bray was intended to bring out audiences by fusing American themes with British arrangements. As one scholar notes, adding “Bray's operatic score to his [Barker's] 'native' story would provide American audiences with the British theatre they demanded in the American setting they admired" (Bak 185). By offering a "melo-drame" which was both of-the-moment and historically based (no matter how specious this history turned out to be), The Indian Princess provided audiences with a popular history that spoke to the topical fears of the early nineteenthcentury. It bears emphasizing, though, that the play achieved these lofty goals due to, not in spite of, Barker's commitment to reaching a wide audience, thus ensuring its financial success within a dramatic marketplace that was becoming more competitive by the moment.

When Barker does turn his attention to the very real struggles of nation-building, he portrays these moments at a further remove from the present by layering them beneath popular songs, a staple of early melo-drame. Thus the "forest drear" with its accompanying dangers for colonists are glossed over in Alice's song in Act I where she sings, “Toils and dangers I'll despise, / Never, never weary; / And be, while love is in thine eyes, / Ever cheery" (120). Barker also uses song to deflect the financial risks that accompanied voyaging to a foreign land and the often violent encounters between Native Americans and the Europeans who met in conflict. In Act II, Larry, Walter, and Robin sing in unison:

We three, adventurers be, 
Just come from our own country;

We have cross'd thrice a thousand ma,

Without a penny of money.

We three, good fellows be,

Who wou'd run like the devil from Indians three;

We never admir'd their bowmandry;

Oh, give us whole skins for our money.

We three, merry men be,

Who gaily will chaunt our ancient glee,

Though a lass or a glass, in this wild country,

Can't be had, or for love, or for money. (136)

Here Barker scatters common colonial anxieties amidst rhyming couplets, achieving two competing goals: giving voice to the very serious danger of this historical voyage (for both colonizer and colonized) and maintaining a light-hearted tone through song onstage.

According to Michael Pisani, music "remains an unspoken and too often unacknowledged contributor not only to the social history of America, but to the creation of its folkways and myths as well" (2). Just as Barker theorizes the nation as a stage for the world to see, the theatre also offered the opportunity to translate the making of America into a song for the world to hear. $^{15}$

As should by now be clear, The Indian Princess offered a coherent idea of America as a nation if the audience didn't look or listen too closely, for even in a play interested more in myth than history, colonial anxieties seeped through. I conclude this section, then, with an example 
that further illustrates the displacement of history in The Indian Princess. I refer here to the first moment when Pocahontas comes onstage in Act I. Pocahontas enters, according to Barker's stage directions, "from the wood, with bow and arrow, and a flamingo (red bird)" with "music as she enters" (123). It is worth pausing over this description, which helped lay the groundwork for later iterations of Pocahontas. We are likely so accustomed to such descriptions as to find this early version of Pocahontas onstage unexceptional. Yet in this single scene, Barker articulates his entire national theatrical project. By calling for Pocahontas to enter the stage "from the wood," Barker aligns the theatrical performance space with settlement and Euro-American culture in opposition to native spaces, which remain offstage, othered and wild. Pocahontas is similarly othered as she carries bow and arrow, a young woman who finds herself, as soon as she sets foot onstage, displaced from her own native, "wild" culture and subject to the gaze of the Euro-American audience in the theatre.

But what of this strange addition, the flamingo that accompanies Pocahontas out of the woods and onto the stage? After all, Barker goes beyond offering stage directions that could be set aside by a director. Instead, Pocahontas's first words of the play make sure that the audience can't miss this exotic "red bird": "See Nima," Pocahontas instructs her attendant, "a flamingo" (123). As the "Indian Girls crowd around, and admire the bird," Barker uses this moment to signal a transformation already completed at the beginning of the play. Pocahontas swears to "use my bow no longer," a statement that marks her as civilized enough for a Euro-American partner. It is also within this scene that Barker anticipates a staple of later melodramatic works, the tableau, with the image of Pocahontas, the "red bird," and her bow lingering in the minds of audience members long after the curtain dropped on the production. The tableau, as Anne Williams points out, is based on the assumption that "language is second best," and "only facial 
expression and bodily gesture" can adequately represent the pathos of a scene (468). Barker's tableau anticipates the tableaux vivants (or living pictures) that would become a popular phenomenon in antebellum America, with many of these performances depicting scenes from history (Chapman 24). Beyond simply doubting the efficacy of language to grasp the past, these later performances upheld embodied performance as the best means of recreating history. Barker's near-tableau offers a snap-shot of an historical figure, but, like the rest of his drama, he struggles to resist admitting the signals of myth into view.

That Barker highlights this odd intrusion, and that doing so does not distract from his bid to put American origins onstage, stands as a testament to his melding of myth and history. He achieves this incongruous pairing by sheer force of will: just as Barker matter-of-factly skims over the challenges of settlement through song, here he locates the place of settlement as exotic and stagnant, a place frozen in time and space, which welcomes the contradictory images of history and myth, and in doing so takes audiences to a place that is somewhere else. This utopic place offers a view of America where international tensions have been resolved, where the Native American "problem" has been dealt with, and where nature has been settled. If audiences noted any incongruities between this view of the nation and their own experiences outside the theatre, they were lost amid the exotic sights and melodious sounds of this collective national history.

\section{Charlotte Barnes' The Forest Princess}

Forty years after Barker's play was first performed in Philadelphia, Charlotte Mary Sanford Barnes' The Forest Princess premiered in the same city at the Arch Street Theatre. ${ }^{16}$ The intervening years were hardly uneventful, as 1848 found the nation on the cusp of yet another 
transitional phase. As in 1808, a return to American origins seems to coincide with spatial and geographic disruptions in the new nation, which had grown from a population of 7 million in 1810 to more than 23 million by mid-century. ${ }^{17}$ The acquisition of Louisiana in 1803 expanded the U.S. significantly, and the end of the Mexican-American war in 1848 shifted the U.S. border all the way to the Pacific coast. President Polk's desire to extend U.S. borders no doubt forced citizens to redefine nationhood in this age of growing American might, as 500,000 square miles of land were absorbed by the United States with the stroke of a pen. The 1840s also marked an influx of foreign workers who immigrated to the U.S. to escape economic and political hardship at home at a time when the nation was experiencing an industrial boom. The result, according to Matthew Frye Jacobson, was "a growing nativist perception of these laborers as themselves a political threat to the smooth functioning of the republic" $(41) .{ }^{18}$ This shift redefined the makeup of America and the gold rush that followed on the heels of the treaty of Guadelupe-Hidalgo found California populated by a diverse mix of "49ers," with immigrants from Peru, Chile, Australia, England, Ireland, Germany, France and Holland contending with Native Americans in the search for wealth (Rowe 150-1).

The experience of being unmoored manifested itself acutely in eastern cities such as Philadelphia. In the preface to A History of Philadelphia (1839), Daniel Bowen speaks to the changes taking place in the city in a "guide to citizens and strangers." "The gradual changes which time makes, in men and things," writes Bowen, "are scarcely perceptible, to those who are present, and observe them, as they take place. It is he only, who has been many years absent, and returns that perceives the extent of these changes" (1). William Wells Brown puts a positive spin on Philadelphia's transformation, assuring those who leave "a city or town, and return after many years, expecting to find, old familiar things, and well-known faces to welcome him" that they 
will encounter "nothing but the marks of time, and the progress of improvement" (1). Still, it is difficult to square these statements with the erasures carried out in the city during the early nineteenth century. Gary Nash contends that Philadelphians had not yet turned their attention to preserving the city's past. In 1812, for instance, Benjamin Franklin's home was torn down and subdivided (2). Describing Philadelphia between 1815 and 1860 as a city in flux, Nash further notes that it was during this period that the city became the nation's industrial center as the population swelled from less than 100,000 to nearly half a million (144). Rather than charting the vast changes in the nation's former capital, members of the Historical Society turned their attention to the Revolutionary period, indicating an intense interest in the city's past, if not its changing, often violent present (Nash 158).

Growing up in this period of rapid change, Barnes spent much of her youth in various playhouses as a child of the professional American theatre. Her parents played lead roles in New York's Park Theatre and Charlotte first graced the stage in 1822 when she was just three years old. Her marriage to E.S. Conner, manager of the Arch Street Theatre, further cemented a lifelong attachment to the stage where she struggled to stand out from her mother's theatrical shadow, even when acting in plays of her own creation (Kritzer 24). ${ }^{19}$ It is perhaps because Barnes felt the insufficiency of her own dramatic legacy that she became interested in the intersections of theatrical and national histories, as she turned her attention to Barker's The Indian Princess and George Washington Parke Custis' Pocahontas (1830), plays that she felt strayed from historical accuracy in their sensational portrayal of this pseudo-national history. Jeffrey Mason argues that myth and history are both merely "textual representations," and that in modernity we can "decide whether to regard a given composition as myth or history" (6). Barnes' resituates these assumptions, though, as it becomes clear that playwrights even in this 
early period resisted conflating such antithetic terms.

What scant criticism exists on The Forest Princess tends to offer very little beyond highlighting the ways that Barnes recuperates Pocahontas as more than a hyper-sexualized standin for cultural amalgamation. Thus Rebecca Jaroff ties Barnes' relatively sympathetic portrayal of Native Americans to contemporary Indian removal policies. "The Forest Princess," she writes, "clearly subverts popular Indian plays of the day by supplying Pocahontas with a voice, granting her political status, and allowing her to reject colonial domination” (483). Mary Loeffelholz argues not that Barnes revises previous iterations of the Pocahontas myth but rather Shakespeare's The Tempest, with the young princess becoming a more developed Miranda who acts with motives that move beyond the romantic, leading us to see "the world-historical importance of Pocahontas's life" (70). To be sure, Barnes offers us a more developed Pocahontas character, one that poses challenges that were largely absent for audiences of Barker's rendition. Most notably, Barnes moves the story beyond the colonial encounter to the trans-Atlantic world in her third act, which follows Pocahontas and the Virginia Company back across the Atlantic to England. This addition forces audiences to engage with the whole of Pocahontas's life, a move that achieves two goals: first, it rescues the forest princess from being seen as important only in so far as she saves Smith, and second, it allows Barnes to depict Pocahontas as a historical figure whose life had been severely truncated in the public record.

Yet these discussions, crucial as they are to recovering an important playwright like Barnes, have hardly focused on the dramatic text left behind. This is particularly surprising given that Barnes' play seems more interested in becoming a work of lasting textual significance than Barker's play, which seems intended only to inform the stage production. In both The Indian Princess and The Forest Princess textual introductions reveal key differences in how the 
respective playwrights view the merits and limitations of the early American stage. In his introduction, Barker undersells the worth of his play, claiming that he feels "so fully conscious of the very humble merit of this little piece, that perhaps nothing but the peculiar circumstances under which it was acted should have induced me to publish it" (115). Being modest about his own play seems less than earnest, though, as he concludes in the same paragraph that "dramatic genius...is assuredly native of our soil, and there wants but the wholesome and kindly breath of favour to invigorate its delicate frame" (115). There seems to be an implicit belief that performing American origins may be the most efficient means of embarking on a native drama to rival the British, with Barker just the man to take on this task. The preface takes a proactive stance against critics who so often "apply the birch" simply because America's "unpracticed tongue cannot lisp the language of Shakespeare (116).

While Barker makes passing reference to historical accuracy in his preface, he addresses these concerns more explicitly in an advertisement which falls between the preface and the dramatis personae. "The principal materials that form this dramatic trifle," writes Barker, "are extracted from the General History of Virginia, written by Captain Smith, and printed London, folio, 1624; and as close an adherence to historic truth has been preserved as dramatic rules would allow of' (117). For Barker the textual must be true, and though the dramatic form may offer challenges to historicity, "historic truth" is nonetheless preserved in the transfer from page to stage, even if this truth can exist only in the utopic nowhere of the early American stage.

The Forest Princess is a text far more uncertain about such preservation. Barnes worries that "the lack of intelligible chronicles has left the early history of the red men imperfect and injustice of their dispossessors have too often falsified or obscured their traditions," while "the various dialects and rapid disappearance of many tribes render perishable the historic songs some 
rude Homer may have chanted" (322). Her concern, here, is that this people and their culturealready fading from view in the cultural consciousness - might be further elided by careless historians (though it should be noted that these worries are distinctly of her time, colored as they are by an inherent belief in the "rudeness" of native culture). Pocahontas thus steps in and "stands forth" as "the animated type of mercy and peace, unselfishness and truth" that holds out hope for Native American recovery (322). It is worth noting that Barnes' Pocahontas is, much like Barker's iteration, made to carry the weight of an entire race, though Barnes seems far more intent on preserving the history of Pocahontas and her people. ${ }^{20}$ If it is true, as Shari Huhndorf argues, that “European Americans have always been obsessed with stories of the nation's origins, repeatedly retelling and refiguring their collective past in self-justifying ways," there is all the more reason to pause over the work of Barnes, a playwright concerned with the difficulties of reaching this past (11).

Why was Barnes, a child of the theatre whose life and livelihood depended on performance, so interested in historical accuracy? One answer to this question may lie in the educational trends of the period. Women were increasingly urged to read history from the early republic through the antebellum period, a prescription intended to allow women to engage with the nation at large. "Since the march of history had created a nation in which home was coextensive with the body politic," Nina Baym writes, "knowledge of history would show republican women in republican homes who they were and what their work was" (13). Republican women, then, become the bearers of historical memory as the result of widespread popular beliefs connecting the study of history and the development of faculties for greater memory. Barnes clearly took this imperative seriously as she researched records of the Jamestown settlement for months in the British Library, and she traded this experience for 
greater credibility as a playwright (Kritzer 25). In her introduction she thanks the Library of the British Museum for allowing her access to "the works, (at least twenty in number) which were consulted previous to the writing of this ephemeral production" (323). Acknowledging the British Museum ties her dramatic project to other works of history and reminds readers of the careful research undertaken by Barnes in constructing The Forest Princess. In keeping with the ideal of republican womanhood, then, Barnes uses her station as a bearer of historical memory to lend credence to her dramatic work in a field that was still largely dominated by men.

Even in this nod toward the ample historical documents at her disposal, though, Barnes is careful to note the ephemerality of the stage performance, and this veil of doubt hovers over her entire dramatic project. Barnes finds the fault lies as much with the conventions of the stage as with careless historians, and it is worth pausing to quote Barnes at length on this subject. In the introduction to The Forest Princess she writes, "The great difficulty in the construction of a drama from this subject,- - its unconquerable defect, rhetorically speaking, lies in the division of the interest. Were it a romance, it were easy to heighten the attraction tenfold by representing love as the result of Pocahontas' compassion and Smith's gratitude, and thus perfecting the unity of plot" (322). Barnes rejects the characterization of Pocahontas as a romantic figure, for since "this tale is no fiction" (itself an interesting turn of phrase), "the justice of such a course may be questioned, especially when, as in the present case, it would detract from the pure disinterestedness of a woman's fame" (322-3). Such self-conscious discourse on the romanticization of the Pocahontas tale reflects Barnes' interest in distancing herself from earlier iterations such as Barker's, but she also separates her Pocahontas narrative from popular works like James Fennimore Cooper's historical fiction or Nathanial Hawthorne’s romances. 
unifying over-simplifies historical narratives such that they become more perfect but less mimetic. It is worth pausing to recount the classical Aristotelian unities of drama: unity of action (a play should follow a single, over-arching action), unity of time (a play should present no more than one day in the life of its characters), and unity of place (the stage should represent a single place). Barnes comments explicitly on the unity of action (which she calls the unity of plot), and the introduction to The Forest Princess admits the difficulties of upholding the unity of time: "The incidents of this play are historical in their most minute detail, but the unities of the stage required the condensation of events into days instead of months" (323). Were Barnes to uphold the unity place, she would have had to abandon her entire third act where the play follows Pocahontas and the Jamestown settlers back to England. Here we see a basic tension between the Aristotelian belief that an artist "shows things not as they are but as they 'ought to be"” and Barnes' belief that historical plays should show things as they were, not as they might have been (Carlson 17).

From our current vantage, it seems entirely reasonable for Barnes to wonder whether or not the stage could put forth an historical product. After all, Barker's play had helped usher in a veritable melodramatic craze, with playhouses pushing sensational melodramas for audiences that clamored for more. Unable to break away fully from the theatre culture of the day, The Forest Princess instead contains elements of two key stages of American melodrama, as outlined by Bruce McConachie: Paternalist Melodrama and Melodrama of Yeoman Independence. Paternalist melodrama (1820-1835), at its core, “defines [upper class males] as protectors, judges, and benefactors, and those under their control as socially irresponsible children" (McConachie 2). Barnes' Pocahontas reinforces this norm early in the play both in her interactions with Powhatan and in her decision to leave her father behind, merely replacing her 
father with the paternal Rolfe. Additionally, Barnes upholds and destabilizes the melodrama of Yeoman independence (1830-55), which emphasized "manly honor, republican independence, and hero worship" that often strayed outside the realm of the theatre (McConachie 68). In Barker's version, John Smith is portrayed as a Yeoman hero who employs the elevated speech of a Shakespearian protagonist. Yet Smith is largely absent from Barnes' play, spending most of the first two acts sequestered onboard the ship, nursing an accidental self-inflicted wound. ${ }^{21}$ While this portrayal of Smith as bumbling adventurer does undercut popular notions of heroism, his honor is reclaimed in act III where he re-enters the drama in heroic fashion. Barnes' tentative attempts to play with the conventions of melodrama are thus thwarted in this final act, signaling an awareness that, in the end, history and melodrama are somehow at odds with one another.

A.E. Lancaster raised a similar concern in 1900 in an article lamenting the lack of a "descendent" to Edwin Forrest or Edwin Booth on the American stage, where he posed a question that remains provocative over a century later: "Can melodrama be a historical play?" (359). On the one hand, history and melodrama would seem to share an interest in "encompass[ing] the entire American experience" with written history reducing the past to a manageable, printed narrative, and melodramatic theatre "reducing it into stageable terms" (Mason 198). On the other hand, the impossibility of achieving this task in print-as theorized by Hayden White - should lead us to see the related limitations of the stage.

Barnes' answer is interesting in its complexity (and in its seeming contradictions) as she crafts a play that, in its performance, follows generic conventions of the melodrama more closely than Barker within what she terms the "third period." This third act seeks to pick up where Barker (and others) left off, following Pocahontas across the Atlantic to London, eight years after the events in Jamestown, giving audiences a wider purview of the changing trans-Atlantic world. 
Where Barker's Pocahontas remained a relatively stagnant character, Barnes' third act emphasizes shifts in more than just geography. Pocahontas, the symbol of American origins, is displaced from her home and her people, and she spends the entirety of this final act being consumed by an unnamed illness. The physical toll that results from her trans-Atlantic displacement is so great that her husband laments, "Great heaven! How changed thou art!" (368). Nor is Pocahontas the only character who experiences such a metamorphosis. In the opening scene, Volday — the play's villain — utters a statement that could apply to nearly all the characters in this play, when he claims, "I'm somewhat changed / From what I was in America" (353).

Barnes gets a great deal of melodramatic mileage out of these unsettled circumstances. With Rolfe held by the King of England on charges of conspiring with Sir Walter Raleigh to “seek Virginia’s crown,” Pocahontas pleads for the life of a colonist once again (358). ${ }^{22}$ Reprising his role as the villain in this third act, Volday brings about Rolfe's imprisonment through a concealed letter, a standard melodramatic trope, which he sends to the King accusing Rolfe and Raleigh of treason. Pocahontas's illness and impending death scene (both also standard melodramatic tropes) lie at the heart of Barnes' foray into melodrama in this third act. Peter Brooks has argued that melodrama yearns to reach the sacred from a distinctly post-sacred plane of a modernity, which reacts to "the vertiginous feeling of standing over the abyss created when the necessary center of things has been evacuated and dispersed" (21). The story of Pocahontas's journey to England adopts this view, most notably in its insistence on looking back towards an American landscape that has been emptied out conceptually. In a soliloquy which cuts both ways (likely because the play was produced in London and in the U.S.), Pocahontas admits that "No classic lore adorns my native land; / But rich, redundant nature reigns alone," (359). Where earlier Barnes voiced her concern for the disappearance of "historic songs some 
rude Homer may have chanted," here history has been displaced and this "new" land is marked as ready for inscription. In short, to meet audience expectations of melodrama, Pocahontas becomes a fragmented figure, at once insistent on preserving native history and at the same time contributing to the very kind of forgetting that proves so worrisome to Barnes.

Analogous fears carry over into the rest of the play in the form of footnotes, which reveal Barnes' anxiety about memory and the American stage. These footnotes can be divided into three categories: additional encyclopedic information, testaments to the accuracy of speech, and admissions of artistic invention. The first category, additional encyclopedic information, is perhaps the least problematic of the three. When Powhatan offers "gold or pearls or silver" for peace with the Europeans, for instance, Barnes notes that "Pearls were found in great profusion in North Carolina and Virginia, and were an important article of barter" (349). Similarly, we learn that Captain Smith's coat of arms contains three heads on his shields to signify that he captured not "one but three [Turks], and killed them all" (364). As if sensing the speciousness of such a claim, Barnes steps in to provide a footnoted citation: "The coat of arms of Captain Smith was confirmed by Garter King at Arms in London: three Turks' heads, on a shield" (364). In both instances, Barnes' footnotes serve not only to enrich our reading of this historical play, but also as an insistent reminder of the solid historical foundation on which Barnes has based her text.

Far more interesting are the second kind of footnotes, what I call testaments to the accuracy of speech. It is in these textual emendations that we come to recognize that two versions of John Smith co-exist in the play: Smith as historical figure and Smith as melodramatic hero. For instance, as Smith argues for patience rather than action against the natives (Volday's preferred method of dealing with Powhatan and his people) Smith falls back on military terms 
which seem divorced from the rest of the dialogue: "Then hear me, by St. George! If ye / Will thus desert your comrades, as ye pass_ - For pass ye must—within the cannon's range, / With sakre-falcon and with musket shot / I'll fire upon your pinnace, and I'll sink / Ye all!" (336). Barnes attests to the historicity of this statement, footnoting that "These are the words recorded as having been uttered by Smith on that occasion" (336). We are left wondering, though, why this particular speech deserves to be transcribed from history, especially given the jargon saturating the passage. One answer may be found in the biographical details of Smith that may lead us see him as more of a buffoon than a hero. After all, Smith remains mostly offstage in this play due to a self-inflicted wound resulting from a careless handling of gun powder. Transcribing this passage, then, recuperates Smith as a man worthy of heroic regard (even if Smith supplies the narrative on which the play is based) as the foundational figure in a national history.

If Barnes' testaments to the accuracy of speech accentuate the bifurcation of John Smith, they also speak to the impossibility of striking a clear balance between Pocahontas' history and dramatic storytelling. In act II, Pocahontas tells us, "The sun's my father, and the earth / My mother: on her bosom I'll repose, / When I have need of rest" (342). This particular bit of transcribed dialogue is inserted into a longer speech that is ostensibly created by Barnes, a move that highlights the permeable boundaries between history and invention. The author's note for this passage claims that, "speeches enclosed in quotation marks are taken from 'recorded examples of Indian eloquence"” (342). As we have seen, Barnes was intensely interested in preserving a Native American history, and so inserting "recorded examples" of Native American speech held symbolic significance. Preserving Native American speech was hardly a novel initiative. Smith himself, in The Proceedings of the English Colonie of Virginia (1612), included speeches "to show the cleverness and guile of Powhatan and Opechancanough in their dealings 
with the English colonists and to demonstrate his own superior ability as he escapes the trap they set for him" (Gustafson 7). Note, though, that Barnes' footnote folds in on itself, as a tautology that leaves a reader to question her claims to historicity. By using quotation marks to denote transcribed speeches in the drama proper and putting inset quotation marks around "recorded examples of Indian eloquence," Barnes destabilizes her entire project and, unintentionally or not, presents these speeches as baseless signifiers, in conversation with other texts but without a seminal history.

Finally, Barnes uses footnotes as admissions of invention, though even here they are often tied to historical research. Thus when Powhatan claims he "never bends his knee, / But standing, prays to Him Who, of all creatures, / Made man, alone, erect," Barnes steps in to provide further explication (348). "Powhatan's refusal," she writes in a footnote, "to kneel is minutely dwelt upon by the historians; but as no motive is assigned, I have given that which seemed most probable" (348). As a playwright-cum-historian, Barnes once again reminds us that she determines what is most probable based on a careful perusal of the admittedly minute writings on this episode. By reading Powhatan's gesture of defiance as religiously motivated, Barnes signals a character based in history but shaped in the present.

Barnes, though, was thoughtful enough to recognize and admit to "several anachronisms" that her melodrama rendered "necessary" (323). Indeed, she concludes her play with a fantastic anachronism that is not entirely dissimilar to Barker's aforementioned flamingo in The Indian Princess. With Pocahontas succumbing to illness, Barnes provides the most detailed stage directions of the play, which I quote at length below:

In the performance of this drama, the stage thus illustrates the Vision of Pocahontas: A strain of invisible music is heard, and thin clouds obscure the view from the casement. 
The clouds gradually disperse and discover the open sea, across which the "George" is seen to sail. This view fades and gives place to the mouth of the James River with its forest, its rude fort, and wigwams. On the banks stands Powhatan, awaiting his daughter's arrival in the ship, which is seen approaching the shore. Clouds again obscure the scene, and through them a figure of Time passes, beckoning Peace, who follows. The clouds partially disperse, and disclose in the distance the form of Washington. The Genius of Columbia stands near him. Time hovers near, and Peace encircles with her arms the Lion and the Eagle. A mist then conceals the allegorical group, and again dispersing, discovers the grand view of Gravesend, at sunset, with the George at anchor, as it appeared previous to the vision. The music dies away.

Here chronology is collapsed as Pocahontas and Washington cross time and space to signal the unity of a people and a nation. But how are we to reconcile this allegorical trinity (Time, Peace, and George Washington) with the claims to historicity that saturate this dramatic piece?

We might begin by locating this specific scene as part of a larger cultural event, the rise of the moving panorama. These panoramas (with exhibitions reaching their peak in 1848, the year of The Forest Princess' first performance) consisted of paintings scrolled across a stage in front of an audience, which "simulated travel through a landscape" with the length of panoramas reaching up to a half mile (Moldenhauer 229). While many of these moving panoramas were purely scenic (see, for instance, John Banvard's depiction of the Mississippi River), this form of performance was increasingly associated with geography and history. Often set to music, audiences also listened to a lecturer who pointed out the "patriotic significance, or pathos" with each passing scene, lending the entire spectacle an air of educational significance (Moldenhauer 231). By their very nature, these panoramas could meld historical moments across time and 
space, linking the present with the past, both literally and figuratively. I suggest that this is precisely what Barnes intends in the scene described above. The panorama, then, would unfold with the following scenes: a view of the open sea, the mouth of the James River with Powhatan standing on the banks, followed by the allegorical figures of General Washington, Time, and Peace, and finally, the anchored ship. "Pocahontas' Vision" thus brings together a host of competing national icons, with Washington and Powhatan as dual "fathers" of the nation, a parallel that unites the Jamestown colony with the American Revolution.

Once again, however, Barnes' play shows us a playwright who is unconvinced of her success in achieving these goals. Being "endowed with temporary strength" from such a moving vision, Pocahontas first exalts Washington as "By heaven named to set a nation free," and she prophesies, "By ties of love and language bound, I see / The island mother and her giant child / Their arms extend across the narrowing seas, / The grasp of lasting friendship to exchange!" (367). Barnes comments on these proceedings in an attached footnote, further illustrating the very divide that the moving panorama was meant to patch. "The belief in prophetic inspiration at the hour of death," writes Barnes, "was, and is, general among the American red men; and although Pocahontas died a Christian, the new faith could not fail to be tinged by the hues of her early association. The embodiment of her prophetic vision by allegorical scenes and figures, was a necessity consequent upon the acting of the drama" (367).

The two parts of this statement are worth unpacking. First, Barnes provides a nowfamiliar explanation for a perceived religious inconsistency as she chooses to have Pocahontas both ways, as a reformed Christian who nonetheless stays true to her decidedly non-Christian roots. In this way, Pocahontas becomes the ultimate example of American hybridity, representing tradition and progress. Jeffrey Richards posits that melodrama is "uninterested in 
shades of meaning or ambiguities of interpretation," but here Barnes highlights these ambiguities even while trying to explain them away ("Introduction” xxxv). Second, Barnes locates the phenomenology of the stage as being allegorical in nature, which restricts our ability to get at the past. Though Barnes set out to place Pocahontas' "true" history onstage, in this third act she gives up her historical project altogether and in so doing, she theorizes the stage as a space not of mimesis but rather of embodied allegory. Put differently, the bodies in motion on the stage disrupt the stasis of history, which Barnes attempts to remedy through the panoramic qualities of "Pocahontas' Vision."

This conflict remains present even in the final scene of The Forest Princess where Barnes reverts from the moving panorama to the frozen pose of the melodramatic tableau. With Pocahontas and Rolfe reunited just before her death, Pocahontas has only words of resignation for her husband ("I warned thee of this parting months ago") and Rolfe cries out his wife's given name, a significant change from the rest of this third act where Pocahontas is referred to as Rebecca (368). ${ }^{23}$ Pocahontas then speaks her final words, ostensibly towards the audience in attendance:

\section{"That name!}

My own! The first by which thou knew'st me, love!

'Tis music to my soul....

I lose thee now.

My eyes behold Virginia's grassy turf.

I hear my father. Husband, fare thee well.

We part, but we shall meet—above!" (368).

Barnes describes the final tableau in this manner: "Her right hand, which has been momentarily 
pointed upwards, falls, and she dies in the arms of her WOMEN. ROLFE still remains upon his knee, clasping her hand and gazing upon her in utter despair. SMITH bends over him in silence" (368). In the case of The Forest Princess, Rolfe genuflects before Pocahontas, elevating her death to the realm of martyrdom, the last remnant of America's native past and a gesture that moves Pocahontas one step further from the "truth" of history and one step closer to the realm of national mythology. If "the melodramatic message must be formulated through other registers of the sign" than mere words, the tableau as a staple of melodrama suggests that gesture could help fill this void, as a sign for the unexpressed sacral moment, motioned towards if never reached (Brooks 56). Barnes falls back on the conventions of melodrama (i.e. the tableau) to show us a past that words fail to achieve, but her footnotes contradict this very message, suggesting that the melodramatic mode could not carry the burden of history alone.

By staging Pocahontas narratives, James Nelson Barker and Charlotte Barnes transformed a discourse of national place into a theatrical staging of national origins. For Barker, the history of America was reduced to a staging of the colonial moment when Euro-Americans took their place on the stage for all the world to see. Barnes' more progressive understanding of American place-making can be understood through her ambivalence about the very process of transforming national discourse into theatrical staging. She concludes her introduction by claiming that the "incidents of this play are historical in their most minute detail," which "the reader of history will at once perceive" (323). By emphasizing the reader of history, Barnes implies that no amount of historical research could overcome the displacement at the core of the early American theatre, which turned her attempts to place history onstage into a dramatic narrative outside of time and space. 
Notes

${ }^{1}$ The Contrast ran for four performances in New York in 1787. It was performed in Philadelphia and Baltimore that year, and subsequent stagings were held in Boston, Charleston, Alexandria, Richmond, and Spanish Town (Jamaica) (Richards, “Contrast”, 4).

${ }^{2}$ Not content to simply give up on André, Dunlap reworked the play into a more overtly patriotic drama in 1803's The Glory of Columbia-Her Yeomanry!

${ }^{3}$ In his History of the American Drama, Arthur Hobson Quinn lists (in addition to the plays by Barker and Barnes) G.W.P. Custis’ Pocahontas, or the Settlers of Virginia, Robert Dale Owen's Pocahontas (1837), and John Brougham's Pocahontas, or the Gentle Savage (272-3). Lehigh University's online Pocahontas archive adds Albert M. Gilliam's Virginia, or Love and Bravery (1829), which was performed in Richmond, VA, though no copies of the play survive.

${ }^{4}$ Robert Dale Owen's Pocahontas: A Historical Drama (1837) sets out to present a more historically factual performance, but, as Robert Tilton points out, Owen "strays more from 'recorded history' than he would like his readers to believe" (74).

${ }^{5}$ See, for instance, John Davis's Captain Smith and Princess Pocahontas, An Indian Tale (1805).

${ }^{6}$ For scholars like Ed White, The Generall Historie can and should be read literarily rather than historically, as he argues that Smith was a colonial novelist, noting the "novelistic dimensions of Smith’s prose” (489).

${ }^{7}$ See Rasmussen and Tilton's Pocahontas: Her Life \& Legend for a summary of the scholarly skepticism regarding Smith's presentation of Pocahontas as savior (18-19).

${ }^{8}$ Barker's play achieved a level of success, being performed in New York's Park Theatre 
and a revised version of the play was later performed in London's Drury Lane in 1820 (Quinn 139).

${ }^{9}$ I don't wish to imply that the colonial theatre scene was entirely absent. For instance, Odai Johnson chronicles the recent uncovering of a 1760 playhouse in Williamsburg, Virginia, built by David Douglass. Far from a fringe site for performance, this playhouse "was a permanent, purpose-built theatre, a substantial brick and timber edifice... situated...on Capital Square, at the center of colonial power" (24).

${ }^{10}$ Heather Nathans makes a similar argument, claiming that the renewed theatrical vigor following the ban may have led some to associate theatre patrons with "partisan politics and factionalism" (6). In other words, the playhouse became a microcosm of the political divisions that were becoming more apparent each day.

${ }^{11}$ Indeed The Indian Princess joined Dunlap's André, James Ellison's The American Captive, or the Siege of Tripoli (1811), C.E. Grice's The Battle of New Orleans (1815), and S.B.H. Judah's A Tale of Lexington (1822) (Quinn 154-56).

${ }^{12}$ Gordon S. Wood claims that in the years following Jefferson's term as president, the U.S. government "was weaker than at any other time in its history" (301).

${ }^{13}$ As in Shakepearean comedy, these marriages restore order by pairing characters of the same class, and so while Barker unites Europeans and Indians, it seems he does so with the "appropriate" class hierarchy in mind.

${ }^{14}$ Barker may have avoided taking a stance with regard to removal because of competing beliefs about how best to resolve the "problem." According to Anthony Wallace, the man in charge of creating Indian policy, President Jefferson, believed that the Indian people must 
"ultimately adopt the white man's ways in order to survive," and that the government should provide these people with the "tools and education necessary to ascend from the communalistic hunting stage to the level of agricultural society with private property" (226). In other words, the goal was first to assimilate before resorting to removal.

${ }^{15}$ Sarah Hibberd and Nanette Nielson seem to agree, arguing that "music can, of course, work in conflict with speech and gesture, undermining what we are being told by the characters in order to suggest trouble ahead, or to imply the duplicitous nature of a particular character" (33). In the example given here, music (or more accurately, song) allows characters to disguise anguish through melody.

${ }^{16}$ The play premiered in Liverpool, England in 1844.

${ }^{17}$ Note, for instance, the rapid political changes occurring during this period. In a Time magazine retrospective, Kurt Anderson sums up the first months of this year at home and abroad thusly:

On Jan. 24, gold was discovered accidentally on a river in Northern California - the first fleck of what would quickly become more than a thousand tons. Nine days later, a treaty was signed ending the U.S. war with Mexico — our first elective war, first imperial warin one stroke extending the U.S. from the Texas border to the Pacific. At the same moment in London, meanwhile, a 29-year-old German philosopher named Karl Marx and his 27-year-old textile manufacturer friend Friedrich Engels published a pamphlet they called the Communist Manifesto. And days later, revolutions broke out in Europe, first in Paris, which overthrew the French monarchy, and then in several dozen other places on the continent. (par. 3) 
The combination of an expanding nation — both in terms of population and geography — and an unsettled political climate abroad aligns 1808 with 1848, perhaps prompted a necessary return to American origins

${ }^{18}$ The largest influx came from Ireland as a result of famine (Frye 40-1).

${ }^{19}$ Barnes' most well-known play was Octavia Bragaldi, a tragedy performed in 1837 at New York's Park Street Theatre with the playwright assuming the title role (Kritzer 24).

${ }^{20}$ Of course, this is a problematic implicit claim, for it marks Pocahontas as a stand-in for all Native American tribes, flattening the true diversity of tribes in early America.

${ }^{21}$ Smith writes of the incident in the third person: "Sleeping in his Boate, (for the ship was returned two daies before) accidentallie, one fired his powder-bag, which tore the flesh from his body and thighes, nine or ten inches square in a most pittiful manner" (193).

${ }^{22}$ This third act also brings us further details on Smith who, it seems, has a habit of being rescued by women. Smith boasts, "Renown and arms are still my only love. / When wrecked on Gallia's coast, a woman nursed / And succored me. In America, / The Lady Pocahontas twice preserved / My life at peril of her own.” (356)

${ }^{23}$ Though she was originally named Matoaka, she was more popularly known as Pocahontas throughout much of her adult life. 


\section{Chapter Three: Misplaced Sympathy: Depicting Slaves in "Foreign" Lands}

On March 2, 1865 The New York Times ran an advertisement for the city's Winter

Garden Theatre that was sure to catch the eye of avid theatre-goers. "Remember!" the advertisement proclaimed, "THE LAST NIGHTS OF HAMLET are drawing near” ("Amusements" 7). Though advertisements in this period often drummed up interest by pitching "last shows," in this case the truth was on the copywriter's side. Starring as Hamlet, Edwin Booth was nearing the end of his run, having put in eighty-two consecutive performances of “ONE OF THE NOBLEST PIECES OF DRAMATIC ART EVER SEEN IN ANY LAND OR IN ANY AGE.” This great work of Shakespeare, so the advertisement went, transcended the history of the theatre and, perhaps more importantly, traversed geographical borders as a play set in Denmark, written by a British playwright, and, in this instance, performed in the United States.

If readers scanned down to the bottom of the advertisement, they would have found a somewhat less enthusiastic announcement for Dion Boucicault's The Octoroon, a play that was first performed at the Winter Garden Theatre in 1859 but hadn't been staged at this site for three years. The contrast in these adjoined notices is readily apparent. Where Booth's rendition of Hamlet offered "SPLENDOR OF SCENERY" that bridged geographic, national, and literary divides, Boucicault's drama is given but one seemingly simple description, as a "great drama of SOUTHERN LIFE and SOUTHERN SCENES.”

Connecting the capitalized phrases of the advertisement helps us parse out The Octoroon's allure for audiences. This advertisement aimed to capitalize on the curiousity of Northern theatre-goers regarding the American South, but it was merely the latest iteration of a larger, long-term trend in which the issue of slavery became a popular topic of conversation. 
Indeed, as I will show, by the mid-nineteenth century American readers and audiences had come to expect depictions of slavery on the page and the stage, even if writers and playwrights were careful to set their narratives outside the U.S.

This chapter sets out, then, to address a question often posed in the study of early American drama but rarely answered: what are we to make of the depictions of slavery set in "foreign" lands and what relation do they bear on slavery in the U.S.? In early works from the period-such as Susanna Rowson's play Slaves in Algiers (1794), Royall Tyler's novel The Algerine Captive (1797), and Robert Bird's play The Gladiator (1831)—slavery was depicted, for the most part, "safely" outside the United States. I will compare these early works with George L. Aiken's Uncle Tom's Cabin (1852) and Boucicault's The Octoroon (1859), for in both of these plays Northern audiences viewed depictions of Southern plantation life with its distinctly American inflection of slavery.

What seems to tie all of these works together is their interest in what it means to be American, and how, venturing to describe a nation and its people, these writers negotiate the slippery and shifting nature of what it means to be foreign. For Rowson and Tyler, this meant subscribing to an essential belief in American-ness which was capable of persisting in foreign climes and, for Bird, in days long past. ${ }^{1}$ For Aiken and Boucicault, on the other hand, this meant reveling in the exoticisms of the South, a place so different as to be foreign for the vast majority of Northern audiences. More germane to this chapter, though, are the ways that these playwrights actively work to redefine what it means to be foreign in the new nation, raising the question of whether or not Uncle Tom's Cabin or The Octoroon should actually be read (or viewed) as abolitionist plays. In these plays slavery becomes more a conduit for defining nationhood—-to the exclusion of those slaves who were already displaced non-citizens - than a practice in need of 
abolishment.

White actors disrupted the phenomenology of the stage when they "corked up" to perform the displacement of these "visible symbol[s] of legal nonpersonhood" (Wald 43). As I have discussed in previous chapters, early Americans experienced the theatre as a theatron, with the stage functioning as a space where audiences could look upon the nation, and, through the bodies onstage, its citizens. How, then, could playwrights write their way around this feature of the stage? Put differently, how did they deal with the disruption that performances of enslaved bodies brought to the stage? In Uncle Tom's Cabin and The Octoroon we find one answer: Aiken and Boucicault consistently emphasize the placelessness of slaves onstage so as to mark slavery as a foreign affair rather than a domestic concern. The stage could thus remain a reflection of the nation, but only by carefully dislocating the enslaved bodies that would have otherwise disrupted this persistent conceit.

By dramatizing the displacement of slaves in the antebellum United States, these playwrights also unsettled the standard melodramatic mode, which relied on a culture of sentiment. I use the term "displaced" here to designate characters whose sense of place is denied (or, at the very least, severely restricted) by those in positions of power. In their introduction to Space and Place: Theories of Identity and Location, Erica Carter, James Donald, and Judith Squires define place as "space to which meaning has been ascribed" (xii). Lawrence Buell builds on this definition, noting that place is more difficult to pin down than its "sibling" time, and "much of this slipperiness derives from 'place' having by definition both an objective and a subjective face, pointing outward toward the tangible world and inward to the perceptions one brings to it" (59). As legal, social, and cultural nonpersons, slaves in the U.S. were subjects of white power but denied the subjectivity needed for transforming space into place. $^{2}$ 
Using the lens of space and place supplements the scholarship of Saidiya Hartman, whose work on audience empathy has helped redefine notions of what it meant to empathize with slaves presented onstage. I will first suggest that sympathy is a more useful term than empathy, both because of its ubiquity in antebellum culture and because it more accurately connotes the distance between white audiences and performances of slavery. In addition to the conceptual space that always exists between character and actor, and between actor and audience, this distance was also articulated in geographic (southern settings), and spatial (the segregated spaces discussed in the next chapter) terms. Where Hartman argues that "empathy [emphasis mine] fails to expand the space of the other," instead merely placing "the self in its stead," this chapter considers the tension that results when a sympathetic audience finds itself in the stead of a displaced other (20). The result, in effect, was that abolitionist-leaning audiences found themselves in a curious double-bind: they could sympathize with these displaced others, but to do so was to be confronted with their own placelessness, and to be reminded of the tenuous threads that hold a nation and its people together.

\section{Slaves in Algiers and Rome}

Boucicault and Aiken may have brought performances of slavery to the masses, tapping in to the topical debates that would erupt in the Civil War, but they were hardly the first writers to project slavery as a subject worthy of discussion. In the interim between the Revolutionary and Civil Wars, Americans often turned their collective gaze to slavery, and these depictions tended to offer a view at a "safe" remove from American soil. In the early nineteenth century, these representations often came in the form of sermons, plays, and short stories about the Barbary States, perhaps the most pervasive slave narrative of the period (Margulis 17). As 
Elizabeth Dillon shows, Barbary captivity narratives fascinated Americans, at least in part, because they engaged the moral and economic debates just beginning at home over an old problem: how to overturn a system that enslaved hundreds of thousands of men, women, and children without compromising conceptions of a unified nation (Dillon 422). Barbary captivity narratives did more than simply engage those willing to be entertained by slavery without explicitly discussing the political ramifications of holding other human beings in bondage. According to Matthew Pangborn, these tales provided a "badly needed political cohesion" during the tumult of the French Revolution, the Whiskey Revolt, Shays' Rebellion, and the Alien and Sedition Acts of 1798, all of which contributed to a growing sense that "the American experiment seemed at any moment to come undone" (2).

In the midst of such political unease, Americans went where they often did to mitigate their deep-seated fears: the theatre. Susanna Rowson first dramatized the American conflict with Barbary pirates in Slaves in Algiers, which premiered at Philadelphia's Chesnut Street Theatre on June 30, 1794. Rowson herself took the role of Olivia, the American woman captured by "an Algerian corsair" and separated from her mother, Rebecca Constant. As mother and daughter negotiate for power in this foreign setting, the specter of Muley Moloc, the Dey of Algiers, becomes the most significant male threat in the play, though a threat that remains mostly offstage. ${ }^{3}$ Audiences may have interpreted Slaves in Algiers as a commentary on bondage writ large, but in her preface Rowson warns against interpreting slavery in foreign lands as a stand-in for slavery at home:

My chief aim has been to offer to the Public a Dramatic Entertainment, which, while it might excite a smile, or call forth the tear of sensibility, might contain no one sentiment in the least prejudicial to the moral or political principles of the government under which 
I live. On the contrary, it has been my endeavor to place the social virtues in the fairest point of view, and hold up to merited contempt and ridicule their opposite vices. If, in this attempt, I have been the least successful, I shall reap the reward to which I aspire, in the smiles and approbation of a Liberal Public. (57)

Here Rowson prescribes that audiences should be entertained by her play and, if a political argument is to be derived from the performance, it must be an argument that upholds the laws of the newly formed United States, laws that, not incidentally, endorsed the legality of slavery. The fact that Rowson felt compelled to explain away any political interpretations of her play suggests that audiences drew connections between American characters enslaved by Barbary pirates and the plight of those unfortunate men, women, and children under the brutal yoke of slavery in the U.S.

James Fennell's prologue, which would have been spoken from the stage, works similarly to disconnect the slavery presented in Slaves in Algiers from American slavery. Fennell is careful to describe the slavery of Rowson's play as different from the domestic enslavement of blacks within the U.S., most notably by painting those in the colonies as enslaved to Great Britain: "What then behoves it, they who help'd to gain, / A nation's freedom, feel the galling chain? / They, who a more than ten year's war withstood, / And stamp'd their country's honor with their blood" (Rowson 57). ${ }^{4}$ Fennell emphasizes the need for an American collective by substituting political subjugation for actual human bondage, thus ignoring the enslavement of blacks by the very men and women who rallied in resistance to political servitude. ${ }^{5}$ In this context, the prologue sets the stage for a performance that is less interested in engaging with the horrors of human slavery than reminding audiences that American political agency must be vigorously defended even after political independence has been achieved. 
Americans turned to the theatre both to be reassured that this independence would be long-lasting and to be reminded of their collective identity as Americans. When Fennell poses the rhetorical question, "Shall the noble Eagle see her brood, / Beneath the pirate kite's fell claw subdu'd? / View her dear sons of liberty enslaved, Nor let them share the blessings which they sav'd," the audience is painted in broad strokes as a homogeneous and collective entity (Rowson 58). This is, though, only one aspect of the prologue. Much more intriguing is an easy to overlook claim that nonetheless tells us much about how early Americans conceived of their nationhood: "Not here alone, Columbia's sons be free, / Where'er they breathe there must be liberty" (Rowson 58). There is more going on here than a simple veiled threat intended for those who don't subscribe to America's definition of liberty ("there must be liberty"). According to this bit of prologue, America isn’t so much a nation with clearly defined borders as it is a placeless, collective state of being, impervious to foreign influence even when political enemies hold its citizens captive.

By the same token, if America entered the realm of ideology, freed from the constraints of geography, the inverse was true as well: lessons learned by Americans abroad were equally applicable to domestic tensions at home. This is the argument put forth by Joseph Schopp, who posits that setting slavery in an "alien scenario...functioned as an ideal simulation space in which unresolved domestic problems with which postrevolutionary America saw itself confronted could be negotiated and proleptically resolved in a fictional context" (Schopp 293). Nonetheless, most have read Slaves in Algiers as far more interested in reevaluating the place of women in American society than championing the "sons of liberty" or commenting more widely on American slavery. Amelia Howe Kritzer, for instance, finds that "the stage, one of the very few actual public spaces in which the active participation of women was considered legitimate (at 
least, by those who considered the theater itself legitimate), offered a logical, if not always reliable, forum in which to attempt the self-representation denied women by the new government" (151). It is within this forum, according to Kritzer, that Rowson spotlights "communities of women, thereby encompassing women as a group and signaling recognition of their political potential" (153). ${ }^{6}$ Elizabeth Maddock Dillon similarly contends that Slaves in Algiers "explicitly argues for the inclusion of women as rights-bearing subjects in the new nation," while also seeking to tie Rowson's drama of "globalization" to "nationalist development," goals that Dillon finds to be companion ideologies rather than mutually exclusive literary aims (407). Thus, while most scholars find Rowson's play to be a commentary on the place of the woman in the new republic rather than a drama interested in commenting on American slavery, all seem to agree that Rowson uses "the orient as an alien space" for experimenting with progressive ideas that couldn't yet be set in American locales (Schopp 304).

Though perhaps better known for writing the first popular American drama (The Contrast [1787]), Royall Tyler crafted his own captivity narrative in novel form with 1797's The Algerine Captive. ${ }^{7}$ In contrast to Rowson, Tyler widens his depiction of slavery, making it an international concern. Tyler sets the first volume of the novel in America, where we follow Captain (and Doctor) John Underhill from New England to the South, followed by a second volume that takes us to the Barbary Coast. As one might expect, this initial southern trajectory leads Underhill to comment on the "problem" of slavery in America. Underhill feels "awkward and uneasy" after observing a parson "chastising his servant immediately before divine service," an act which runs counter to the physician's "conscience," a "staple of New England" found absent in the South (158). This leads Underhill to flee the South primarily because he is "unwilling to live with the practice of southern slavery" (Hold 502). 
Tyler's tendency to draw parallels between enslavement and other aspects of life, though, works against Underhill's criticism of Southern slavery. For instance, Underhill admits that his own "prior experience in school-keeping, would have determined me rather to have preferred laboring with the slaves on their plantations than sustaining the slavery and contempt of a school" (144). We might draw a useful comparison here to Fennell's prologue in Slaves in Algiers, which equated political subjugation to actual human slavery. If American slavery comes under attack in volume one of The Algerine Captive, then, it does so as part of a larger critique of the distinctly American inability to "recognize the nature of slavery and, therefore, the nature of freedom" (Engell 22).

In volume two, though, Tyler shifts the tone of his novel signficantly: where the early sections of volume one are satirical and aim for comedic effect, Underhill's journey south brings with it a satire "less gentle and more biting," and as readers follow Underhill overseas, the air of comedy falls out of the narrative (Moore xii-xiii). Underhill finds himself being sold into bondage in a slave market scene that would be echoed often in domestic narratives, though here set in Algeria. "It was astonishing to observe," Underhill relates, "how critically they examined my muscles, to see if I was naturally strong," and "though I could not understand their language, I doubt not they spoke of my activity, strength, age, \&c. in the same manner as we at home talk in the swop of a horse" (11). Of course, this scene differs from most of its kind in one key way: here a white man is poked and prodded, reduced to the sub-human state of an item sold at market. Tyler does offer some commentary on slavery in the American South, but Underhill must remove himself to foreign lands (and into the hands of foreign slave-owners) to reach a full realization of the horrors that blacks were subject to on U.S. soil. ${ }^{8}$

Unfortunately, Underhill's lessons are soon forgotten. In a move that resists an 
abolitionist reading, he reflects on his enslavement and return to America in terms that call into question the moral stance of the novel. Once freed from captivity and back on American soil, Underhill purchases "a horse, and hastened home to my parents, who received me as one risen from the dead," and resumes his life of willful ignorance regarding the slaves who reside in the "freest country in the universe" (226). We might read these lines as a satirical statement meant to call attention to the very lack of freedom slaves endured in the colonies, and further proof that Underhill "always acts the fool, [and]...lives to overlook his foolishness" (Engell 31). I would argue that a larger claim is being made here, whether or not Tyler meant for readers to laud Underhill or condemn him: If all that Underhill learns about the evils of slavery he learns overseas, and these lessons are excised swiftly upon his return, we are left to question the possibility of critiquing slavery from within the geographic borders of a slave-holding nation. Just as Rowson is careful to take the audience "somewhere else," to bring Algeria to America, Underhill can only interrogate a discourse on slavery from abroad.

This possibility gains credence when we consider how radical the shared narratives of Slaves in Algiers and The Algerine Captive would have been in the late eighteenth century. Both texts are built on the supremely odd but often overlooked inversion of traditional slave narratives. Slave narratives like The Interesting Narrative of the Life of Olaudah Equiano (1789) or Frederick Douglass's Narrative of the Life (1845) chart the displacement of black bodiesgeographically, culturally, and politically. Rowson's play and Tyler's novel, on the other hand, plot the displacement of white bodies to Africa, where they are subsequently enslaved.

The question of whether or not slavery could be set at home remained relevant nearly four decades later when Robert Montgomery Bird's The Gladiator (1831) hit the stage at New York's Park Theatre. Written as a star-vehicle for Edwin Forrest, Bird's play dramatizes a slave 
revolt led by Spartacus against Marcus Licinius Crassus, a Roman leader whose wealth was built on the backs of laboring slaves. Is it possible that Bird crafted his play as a careful commentary on slavery in America? Writing fifteen years after The Gladiator's premiere, Walt Whitman was confident that "there was little question of the play's abolitionist tendencies" and Bird's own diary illustrates that the playwright "understood the inflammatory potential of his play" (Richards, "Gladiator" 168). The simple fact that "tyranny and slavery were important issues in America" leads one scholar to argue that "in choosing a man of independent spirit, a Thracian bound by slavery, as his hero, Bird showed his sensitivity to the society around him," implying that the play takes up the cause of abolitionists, even if in a veiled way (Meserve 60). Indeed, when Spartacus transforms from slave to master ("When last we met I was a slave: and now / In a Consul's camp I stand a conqueror"), it seems at least plausible that audiences could connect Forrest's words onstage to abolitionist rhetoric (210). This becomes an even greater possibility when we take into account the fact that the bloodiest slave rebellion in the American South, led by Nat Turner, occurred in the same year that The Gladiator premiered.

Other critics of Bird's play, however, are more hesitant to ascribe any intentional abolitionist rhetoric to The Gladiator. For Bruce McConachie, Bird's play upholds a Jacksonian commitment to "traditional honor and Napoleonic authority," but it also plays both sides by setting The Gladiator in "exotic lands," which enabled "liberal and republican sentiments" to share the stage (Melodramatic 96-7). Jeffrey Richards points out that, "It would have been easy enough to see The Gladiator as about the Revolution, with Britain as Rome and the colonials as slaves," but this reading is complicated by the fact that "the only 'slaves' in America were African in origin" ("Gladiator" 168). For those in this camp, Bird's play reveled in the spectacle of slavery without taking a coherent political stance on the issue. 
Bird further distances his drama from commentaries on American slavery not only through locating The Gladiator in Rome, but also by setting the play in the distant, classical, past. Ironically, reviews of Bird's play tend to comment most often not on the play's political potential in the fight against slavery but rather on The Gladiator as a native drama that, for many, fulfilled the promise of an American stage to rival that of Europe. Thus one writer finds that after "the numerous shocking abortions to which our play-wrights have within a year or two called the public attention," Bird offers "a genuine tragedy of native birth" that "may be justly placed in the foremost rank of modern poets" ("Theatre" 3). The Ariel concurred, finding that "as a literary performance, we know of nothing of the kind, which will compare with it" ("Gladiator" 236). In short, The Gladiator achieved the unlikely feat of being received as a distinctly American drama because of its displaced setting in a far-off locale and in a time long past.

In each of the three texts discussed here, then, we can locate a common trend, with early American writers taking on the subject of slavery at a significant remove, both geographically and temporally. Current critical discussions tend to waver on whether or not authors and playwrights intended these texts as reflections on American slavery, with most locating the equivocating nature of novels and plays that both were and weren't engaged in the growing debate. This ambiguity left open the possibility for audiences to see the best of themselves and their nation in these works, while largely ignoring the paradox of slavery in "the land of the free.” As I will show in the following section, Rowson, Tyler, and Bird set the stage for later playwrights who, far from confronting U.S. slavery head-on, instead merely substituted foreign agents for foreign lands.

\section{Redefining Foreign Lands}




\section{George L. Aiken's Uncle Tom's Cabin (1852) and Dion Boucicault's The Octoroon} reminded American audiences of their complicity in the horrors of slavery, or, at the very least, the complicity of their neighbors to the south. When drawing out the connections between these plays and the works of Rowson, Tyler, and Bird, however, we would do well to ask a question which may seem, at first glance, to make little sense given the unrest which erupted just a few years after these plays graced the stage: If it was possible for earlier writers to depict slavery in Algiers and Rome without necessarily commenting on slavery in the U.S., is it also possible that Aiken and Boucicault could craft plays about slaves without engaging head-on with the political and social fall-out from American slavery?

Answering this question is made more difficult by the fact that Aiken and Boucicault adapted their plays from the work of others. Aiken, of course, drew from the most popular novel of the nineteenth-century, penned by Harriet Beecher Stowe. Whether panned as an overwrought work (as Stowe's novel has been for much of its history) or lauded by those who worked to recover the text as a novel worthy of investigation, there is no arguing the clear political aims of Stowe as an abolitionist writer in antebellum America, nor is there any question about the novel's popular influence in American culture. ${ }^{9}$ As Sarah Meer's scholarship on “Uncle Tom mania” illustrates, Stowe's novel gave rise to countless adaptations that were embraced (sometimes simultaneously) by abolitionists and anti-abolitionists alike (2). The adaptability of Uncle Tom's Cabin, for Meer, “demonstrate[s] that a single text can be adapted into hundreds of forms that suit a vast spectrum of political opinions, but they also reveal the concessions and accommodations that have to be made to different genres" (2).

This meant that the earliest dramatizations of the novel were necessarily excised of inflammatory material so as to appeal to the widest possible audience. Still, the versions of 
Stowe's novel that first reached the stage were truncated as much due to time constraints as to political neutrality. In fact, in the absence of concrete copyright law, and because Stowe's novel was such a popular success, playwrights didn't even wait for the novel's serialized ending before putting Uncle Tom onstage. The speed with which performances were brought to the stage also meant that there were a number of nearly concurrent productions. In August of 1852, Charles Western Taylor staged a version at the National Theatre in New York, while Clifton Tayleure produced his play in October in Detroit. Henry J. Conway's version was a relatively late arrival in November of 1853 in New York, even though his play hit the stage barely a year after Stowe's novel was published in its entirety. Thus while Aiken and Conway's versions have received the most critical attention, they competed in a crowded marketplace of peers with designs on profiting from the success of Stowe's novel.

Aside from the dramatic competition, Aiken's largest challenge came from adapting a long novel into a stageable play. Aiken initially wrote a four-act play that concluded with the death of Eva, opening in Troy, New York on September 27, 1852. Due to the popularity of this truncated version, Aiken soon added to his dramatization of Stowe's novel with a new four-act play that recounted events up to Tom's death, opening on October 26 of the same year. ${ }^{10}$ Finally, Aiken gathered and assembled Stowe's novel and his own early versions of the play "into manageable dramatic form" by making the play an episodic affair, dividing six acts into more than thirty scenes. From July 1853 to May 1854, Aiken's production drew huge crowds at A.H. Purdy's National Theatre, even as it competed with Conway's production, which ran contemporaneously in New York for two months (Meer 106). Conway's version and Aiken's adaptation "were advertised and reviewed as competitors and as taking diametrically opposed views on slavery" though they used the same source material, with Barnum's advertisements for 
the Conway version promising to show "the Southern negro embracing all its abhorrent deformities, its cruelties, and barbarities" (Meer 106).

Aiken's version may have been marketed in a less overtly racist manner, but it is more accurate to say that these plays were separated by degrees of racism. In other words, the Conway production was advertised to those of a racist mindset, but Aiken's production shared in the deeply racist conceits of blackface and offered its own stereotypical depictions of "the Southern negro." How was it possible that Stowe's novel could have its abolitionist intents adapted away so thoroughly? One way to answer this question is separate abolitionism from racism. Doing so allows us to locate racism even within an abolitionist text like Stowe's novel. Thus a novel that argues for the end of slavery nonetheless contains white characters that are depicted as more intelligent and more ambitious than the black characters that require salvation. ${ }^{11}$ The culture of racism permeated every face of early American life, even texts or performances that might be seen as progressive for their time.

Many scholars respond to the racism within abolitionist plays by pointing out that the antebellum stage was more often a site of popular entertainment than a place of political engagement. As Jeffrey Richards writes in his preface to Aiken's Uncle Tom's Cabin, “One of the ironies of the period of the 1840 s and 1850 s is that at the very time when the crisis over slavery was coming to a head, American theatregoers were flocking to see escapist shows about carefree blacks" (368). ${ }^{12}$ And, though slavery may seem to be "the perfect melodramatic subject" with its "conflict between rapacious slaves and abducted slaves,...villains and heroes,...tense crises, scenes of entrapment, and last minute rescues," some have argued that melodramas stage "sites/sights of slavery" as "mere resting points in the rush to affirm order at the play's close" $\left(\right.$ Kooy 460-2). ${ }^{13}$ 
Indeed, the conclusion of Aiken's Uncle Tom's Cabin leads Bruce McConachie to describe the play as conservative at its core, for it "suggest[s] that humanitarian sensibility and modest reform can solve the problems of slavery and capitalism without altering the underlying structure of capitalistic culture and society in the $1850 \mathrm{~s} "(7) .{ }^{14}$ This is a damning critique not just of Aiken's play, but also of the broader culture of sentiment from which Uncle Tom's Cabin sprung forth. It is also, in my view, a misguided oversimplification, as McConachie's thesis succumbs to the critical tendency to separate drama into popular and political categories, which fails to take into account works that operated on multiple levels, as I would argue is the case in Uncle Tom's Cabin. In other words, to label Aiken's play as popular, conservative, or comic should not preclude it from also being a politically engaged drama, and the fact that such views persist may be the strongest sign of the ways that Uncle Tom 's Cabin's continues to resist easy categorization. ${ }^{15}$

Scholars of the antebellum theatre have had a similarly difficult time pinning down The Octoroon's stance on slavery. Falling firmly within the melodramatic realm, the play tells the story of George Peyton, nephew of a recently deceased uncle and heir to the Terrebonne Plantation, and Zoe, an octoroon. Mrs. Peyton, George's aunt, fears that she may lose Terrebonne to public auction, as the once proud southern aristocrats have fallen on hard times. The play's villain, Jacob M'Closky, withholds information to ensure that Zoe will be sold along with the other slaves of Terrebonne, at which time he proceeds to purchase the young woman. George, who does not know that Zoe is an octoroon, professes his love to the girl. Unable to marry George and unwilling to accept her fate as property of M'Closky, she commits suicide at the conclusion of the American version of the play.

Like Aiken, Boucicault adapted his play from a novel, in this case Captain Mayne Reid's 
The Quadroon; or, a Lover's Adventures in Louisiana (1856), though this novel was “itself only one of dozens of novels, biographies, and other representations dealing with 'tragic' octoroon or quadroon heroines, beginning in 1836 with Hildreth's The Slave” (Roach 198). Reid admits in the preface to his novel that it "was written many years ago, and would have been then published, but for the interference of a well-known work, which treated similar scenes and subjects" (NP). Lest readers interpret the novel as a referendum on slavery, Reid presents a strained stance of neutrality. "The author disclaims all 'intention,"” he writes:

The book has been written, neither to aid the abolitionist, nor glorify the planter. The author does not believe that by such means he could benefit the slave, else he would not fear to avow it. On the other hand, he is too true a Republican, to be the instrument that would add one drop to the 'bad blood' which, unfortunately for the cause of human freedom, has already arisen between 'North' and 'South.' No; he will be the last man to aid European despots in this, their dearest wish and desperate hope. (NP)

Here Reid develops a laissez-faire attitude toward slavery, articulating a stance that was no doubt intended to increase sales of the novel to citizens on both sides of the Mason-Dixon. Instead of engaging the debate over slavery, the passage redirects the reader's gaze from the civil strife at home to the ongoing cultural war between the U.S. and the "European despots" who, according to Reid, revel in the War Between the States.

Reid's editorial comments, then, lead us to question Boucicault's own stance on American slavery. Boucicault claimed The Octoroon was an antislavery play while testifying in 1866 before the Parliamentary Select Committee. However, Sarah Meer has called this assertion into question, as she claims that Boucicault made this statement merely to appease "the British licensing system, in which the Lord Chamberlain vetted plays for political or controversial 
content" (83-5). This reading is supported by early reviews of the play which tend to note Boucicault's "'shrewd" handling of the slavery issue," determining that he "crafted his narrative to be 'pro-northern,' calling attention to the inhumanity of slavery, while the characters themselves were pro-southern, as the villain is purportedly a 'Yankee' and the southerners are portrayed as generous paternalistic slave owners" (Chiles 29). Revisions to The Octoroon reinforce the view that Boucicault hoped to maximize revenues while minimizing the play's political implications, for Boucicault wrote different endings for the American and British versions of the play. Boucicault only begrudgingly changed the ending of his play after British audiences voiced their extreme displeasure with the ending. The revised British version (often labeled the "English Happy Ending") spares Zoe and leaves she and George with at least the possibility of a happy life together. As in the case of Uncle Tom's Cabin, labeling The Octoroon as an abolitionist play thus neglects the possibility that these plays were the products of a divided, even contradictory culture, capable of playing both sides at once in the chase for greater revenues.

Mapping the muddled political aims of these two plays is further complicated by the fact that Uncle Tom's Cabin and The Octoroon depicted Southern plantation life in front of Northern audiences, audiences that, one might assume, would have been more open to abolitionist-leaning dramas. Northern audiences were certainly more receptive to sympathetic portrayals of slaves onstage, and we can only speculate as to the hostile reaction that either of these plays would have received if performed in the South. Still, while slavery clearly divided the nation, no such clear division could be mapped onto the U.S. In other words, "North" and "South" became terms as much of political ideology as of geographic location. Thus in Uncle Tom's Cabin the most abusive slaveholder, Legree, was raised in the North and has only recently come to the South 
while in The Octoroon Salem Scudder, a man from Massachusetts, is portrayed as a good man, through and through. ${ }^{16}$ Though it is perhaps easy to misread the Civil War as a battle to resolve property disputes (i.e. which states will be governed according to which law), it is more accurate to see this dispute as a debate over who counted as American, a debate that had been present and unresolved since the nation's founding.

Indeed, we need only look back a few years, as Priscilla Wald does, to two related legislative contests, the first two decades before Aiken's play hit the boards, and the second taking place in the interim between the Aiken and Boucicault productions: Cherokee Nation v. the State of Georgia (1831) and Dred Scott v. Sandford (1857). Wald argues that these two cases "represent a contest of narratives each trying to legitimate a version of the official story of the nation, and each complicated by the presence of human beings who embody its unresolved contradictions" (20). At issue in Cherokee Nation was how to define the relationship between Euro-Americans and the Native Americans whose very presence constituted a "hole in the map within the perimeters of Georgia" (26). The Dred Scott case shows a government grappling with whether or not to assign personhood to slaves who followed their masters to territories where slavery was illegal. When taken together, these cases reflect the problems that result from the revision of geographic boundaries in the U.S., and, more importantly, the people who, in the words of Wald, embody "radically differing versions of the official story," thereby posing "a threat to its authority" (17). ${ }^{17}$ Confronted with slaves and Native Americans who resisted the accepted national narrative of white authority, antebellum writers sought to relieve this tension by staging their foreign-ness.

\section{Staging Foreign-ness}


Aiken and Boucicault offered depictions of slavery not all that different from that of Tyler, Rowson, and Bird, when we take into account the shifting definitions of what it meant to be foreign at this time. Indeed, in both Uncle Tom's Cabin and The Octoroon, we catch a glimpse of these "visible symbol[s] of legal nonpersonhood: neither potential citizen[s] nor alien[s]" (Wald 43). It is worth pausing over the description here, and in particular over Wald's decision to describe these nonpersons as "visible symbols," because, of course, this is what the stage adds to Stowe's narrative: visibility through embodiment. Conventions of the early American stage meant that white actors adopted blackface to portray slaves onstage, a practice that unintentionally exposed race as performance, even as audiences, in some cases, "suspected that they were being entertained by actual Negroes" (Lott, Love, 20). This amounted to a crucial difference, then, between depictions of slavery in print and in the theatre. White readers of Stowe's novel could retain their belief in the foreign-ness of slaves, while theatre patrons were forced to consider whites effectively disappearing into the roles of the "visible symbols" that Wald describes.

Thus even in the dialogue that Aiken took verbatim from Stowe's novel, these words take on additional layers of performative meaning. Take, for instance, the opening scene of Aiken's play, where George gives voice to the tenuous nature of place in the lives of slaves. Eliza, his wife, implores him to be patient after "losing your place in the factory," and George responds in anger: "Patient! Haven't I been patient? Did I say a word when he came and took me away-for no earthly reason - from the place where everybody was kind to me" (375). ${ }^{18}$ Later in the play, in yet another piece of dialogue lifted from Stowe, George is even more outspoken about his displacement, and here he connects these feelings to his status as a legal and social non-entity, a man without a nation. Upon being dissuaded from carrying out his plan to rescue Eliza from the 
plantation, a plan "in opposition to the laws of your country," George erupts once again in anger: “My country! What country have $I$, but the grave?" (396). ${ }^{19}$ Unwilling to let this point go, George reiterates his displacement a few lines later, as he claims, "I haven't any country any more than I have any father" (396). The fact that a white actor would have spoken these lines onstage highlights the shared experience of displacement in early America, even if this displacement differed in degree and kind for free whites and enslaved blacks.

Though their individual narratives don't cross paths in the play, Topsy gives voice to her own sense of displacement. When Ophelia asks the young girl who her mother is, Topsy replies, "Never had none," even going so far as to add that she "never was born" (392). Ophelia continues to question the girl, asking when she was born, and Topsy responds, "Never was born, I tell you; never had no father, nor mother, nor nothin'. I was raised by a speculator, with lots of others" (392). ${ }^{20}$ Topsy's comments speak to the horrors of slavery with its tendency to disrupt family units and her comments show that even as a young girl she understands her status as property to be speculated on like a piece of land. She also expresses her inability to be placed, and the frustration that results from coming to this understanding. Topsy's dialogue reminds audiences that the slaves being depicted onstage resist easy definitions in a nation increasingly interested in defining Confederates against Unionists and, more broadly, U.S. citizens against foreigners. Topsy does not fit within any of these organizing categories, and she is painfully selfaware of her liminal position.

Thinking critically about the ways that slaves are displaced onstage stands to shed additional light on one the play's most complex —and controversial—characters: Uncle Tom. In tracing the many different iterations of Uncle Tom from the page (Stowe's novel) to the stage (plays by Aiken and others) to the itinerant minstrel shows that co-opted the character, Sarah 
Meer finds that in "losing the power and moral certitude of Stowe's original Christian slave, Uncle Tom was transformed in the minstrel shows, becoming a race traitor" (15). Yet in the space between novel and minstrel show, we catch a glimpse of Uncle Tom as a slave who is unwilling to stand up for his own freedom or for the freedom of those around him. I would like to suggest, though, that Aiken's Uncle Tom develops into a character not so different from George. In other words, where George opens the play incensed with his inability to secure a place in the South, the play allows us to follow Tom's trajectory, and he ends the play where George begins. Thus at the opening of Act IV, we witness Tom's conversion from a man who endures present atrocities for future salvation to a man who finally realizes his own foreignness, his own liminal state. "Here you are," Cassy tells him, "on a lone plantation, ten miles from any other, in the swamps.... There's no law here that can do you, or any of us, the least good" (433). Spoken on a Northern stage, Cassy's words further dismantle the simplistic binary between North and South, signaling the true displacement of slavery, which offered no asylum for those looking for a nation to call home. Unable to see this for himself, and in opposition to the selfawareness exuded by Topsy, Uncle Tom nonetheless comes to understand his own displacement through the eyes of another. When Cassy tells Tom that she "used to see the picture of Him [God], over the altar, when I was a girl; but He isn't here," it only remains for Tom to leave the land of the living and the world of this play.

In The Octoroon, Dion Boucicault dramatizes the threat of literal displacement for the Terrebonne Estate's slaves, and he was uniquely positioned to dramatize the rapidly shifting place associations of a nation consistently redefining its own borders. As Joseph Roach writes, The Octoroon "was written after a brief period of residence in New Orleans by an AngloIrishman of French ancestry who learned his trade as a melodramatist in Paris" (183). This 
transient experience no doubt came to bear on Boucicault's play. In the opening scene, the newly returned George tries to get his own bearings by asking Old Pete if all the slaves were born on the Terrebonne plantation. In a response that echoes that of Topsy, Pete replies:

Guess they nebber was born—-dem tings? what, dem?—get away! Born here—dem darkies? What, on Terrebonne? Don't b'lieve it, Mas'r George; dem black tings never was born at all; dey swarmed one mornin' on a sassafras tree in the swamp; I cotched 'em; dey ain’t no count. Don’t b'lieve dey'll turn out niggers when dey're growed; dey'll come out sunthin else. (451)

Pete describes the slaves who live on the Terrebonne (which, not incidentally, translates from the French to "good land") as extra-terrestrial, and sub-human. Perhaps more importantly, this description emphasizes the lack of rooted-ness of these slaves. Rather than portraying his fellow slaves as a group uprooted (like, for instance, the American colonists), they are instead unrooted, having no connection to the plantation where they are forced to work, and no true home to which they can return.

Boucicault's displaced slaves stand in stark contrast to the free whites in the play, who, at nearly every opportunity, remind audiences of their ties to the plantation. Though he is only recently returned from Paris, the play's hero, George Peyton, sets himself the task of reconnecting with his family's estate. His first act in the play is to survey the Peyton property as he seeks to replace Paris, for he "left that siren city as" he "would have left a beloved woman" (452). Indeed, Europe seems to have left its mark on the young man, and throughout most of the play George seems somehow tainted by his European travels. M'Closky tells the audience from the start that George is "unacquainted with our customs in Louisiana," and he threatens, "If he [George] brings any of his European airs here we'll fix him" (55-6). Part of the development in 
The Octoroon, and a part that is rarely commented on, is the progression of George from

European dandy to that of a Southern gentleman who stands to save the family estate from being mortgaged. He achieves this transformation through the symbolic act of reconnecting with his family's estate and thereby supplants his European association though a renewed engagement with his family's land.

George's aunt, Mrs. Peyton, is even more explicitly tied to the land she stands to lose if Terrebonne is auctioned off. "I don't value the place for its price," she ruminates, "but for the many happy days I've spent here: that landscape, flat and uninteresting though it may be, is full of charm for me; those poor people, born around me, growing up about my heart, have bounded my view of life; and now to lose that homely scene, lose their black, ungainly faces" (459). Note that her ties to Terrebonne swallow up the slaves who work the land, as the latter become merely part of the landscape. Moments later, Mrs. Peyton pleads with George, saying, "Heaven has denied me children; so all the strings of my heart have grown around and amongst them, like the fibres and roots of an old tree in its native earth" (Boucicault 160). Mrs. Peyton doesn't wish to keep slaves on hand to do the Plantation's work, but rather because her own sense of place includes the terrestrial property and the human chattel. Her slaves function as a physical tie to the place she has subjectively created such that these slaves can be viewed as of the landscape while remaining necessarily foreign to it.

Joining the play's slaves on the fringes of these ever-shifting borders is the Native American character Wahnotee. Wahnotee's very presence onstage, for Matthew Rebhorn, transforms Boucicault's play from the standard "'black-or-white' modalities of melodrama” into what he calls an "amalgamated drama," capable of helping American audiences confront a "host of amalgamated identities on the eve of the Civil War" (9-10). Rebhorn here assumes that 
audiences would have viewed an Indian character onstage as anything other than a cultural oddity worthy of one's gaze if not worthy of inclusion within the polity of the U.S. These assumptions stand in marked contrast to the way other characters frame their interactions with the Native American man. Wahnotee exists in The Octoroon, in the words of Mr. Sunnyside, as a "nuisance" who should "return to his nation out west" (457). Sunnyside's generic "out west" signifies the "troublesome" qualities of Native Americans in the Antebellum U.S., who, as in Cherokee Nation v. Georgia, are somehow foreigners on their native land. It also signals the early American stage as representative of a nation without a frontier: Wahnotee's "nation out west" resists representation and so can only be gestured towards and not reproduced on the stage.

We are left in The Octoroon with two sets of displaced foreigners: slaves displaced from the South who seek in vain to find their place in the nation, and Native Americans like Wahnotee who are told to return to an imaginary home that is described as always west of "here." It was in the far-off foreign locales of Rowson, Tyler, and Bird, that American audiences could most clearly place themselves, while the dramatizations of Southern slavery remained at a conceptual remove, and thus foreign to Northern audiences in New York, Philadelphia, and Boston. The final section of this chapter, then, will examine the tensions that result when sympathetic audiences place themselves in the stead of these displaced characters.

\section{Misplaced Empathy}

Having reached the conclusion that Uncle Tom's Cabin and The Octoroon dramatize the shifting definitions of foreign-ness on the precipice of the Civil War, there remains a significant question to be answered: how do these displaced "foreign" characters trouble the empathetic feelings that audiences may have felt for them? The work of Saidiya Hartman is useful here in 
fleshing out the complexities of what turns out to be a question not easily answered. At its core, Hartman's project in Scenes of Subjection: Terror, Slavery, and Self-Making in NineteenthCentury America has been to interrogate what she calls the "uncertain line between witness and spectator" (4). This investigation leads her to a rather provocative conclusion with regards to white spectators "witnessing” the portrayal of slaves suffering onstage. For Hartman, the permeable boundaries between stage and audience mean that "empathy fails to expand the space of the other," instead merely placing "the self in its stead," thereby resulting in the erasure of the very subject deemed worthy of the empathetic response (20). In other words, audiences might empathize with an enslaved character onstage, but in doing so they merely imagine themselves in a state of bondage, and in so doing, the other is displaced. According to Hartman's logic, the fact that Uncle Tom's Cabin and The Octoroon rely so heavily on sentiment and appeals for audience empathy threatens to negate their political efficacy.

Hartman's argument forces us to rethink simplistic notions of audience and actor as distinct entities, but it is worth pausing to consider her use of the word "empathy." It is certainly useful to discuss audience empathy when looking back on the history of the theatre, but empathy as a term would have been anachronistic in 1850 s America, only coming into use in the early $20^{\text {th }}$ century. While Hartman's term connotes a kind of psychological approach to these plays that offers much to the analysis of interaction between spectator and performer, it may be more useful to conceive of empathy as couched within the more widely used "sympathy." Re-orienting the discussion in terms of sympathy highlights the implied distance and perhaps even hierarchy that this word connotes in antebellum culture. For instance, readers and theatre-goers could empathize with the plight of a mother losing a child, but not a mother who is enslaved.

It seems especially necessary to frame this discussion of empathy alongside sympathy as 
an oft-used antebellum term given its pervasiveness. ${ }^{21}$ Indeed, it would be hard to overstate the ubiquity of "sympathy" as a cultural buzzword in antebellum America and abroad. ${ }^{22}$ In the final chapter of Uncle Tom's Cabin, Stowe helps us grasp the contemporary meaning of this word in all its slipperiness. Stowe writes:

But, what can any individual do? Of that, every individual can judge. There is one thing that every individual can do,--they can see to it that they feel right. An atmosphere of sympathetic influence encircles every human being; and the man or woman who feels strongly, healthily and justly, on the great interests of humanity, is a constant benefactor to the human race. See, then, to your sympathies in this matter! Are they in harmony with the sympathies of Christ? or are they swayed and perverted by the sophistries of worldly policy? (385)

For Stowe, those who feel sympathy for others become ideal persons, capable of greater good for humanity at large. Those who have been "perverted" by "policy” aren't incapable of sympathy, for the feeling "encircles every human being," but they have been misled from the right (i.e. Christian) path. Stowe's discussion sets sympathy in opposition to "worldly" policies in what amounts to a call for a better American whose innate "sympathetic influences" trump inhumane laws.

One outcome of the antebellum focus on sympathy was a surge in reform movements, for reform literature privileges "compassion in calibrating and adjusting the sensations of the reader in finely tuned and predictable responses to what is viewed or read" (Samuels 5). At least partially as a result of the Second Great Awakening, Americans came to see themselves as a people on the verge of destruction and thus in need of reform, and this reform found many channels. In addition to the abolitionist movement, Americans turned their attention to the rise of 
alcoholism in the 1840s. The so-called temperance movement led Americans to expound on the evils of drink through sermons and at public meetings and eventually reform found its way to the stage in William Henry Smith's The Drunkard (1844).

That sympathetic performances became tied to national identity seems clear. As Shirley Samuels writes, "In nineteenth-century America sentimentality appears as a national project: in particular, a project about imagining the nation's bodies and the national body" (3). The theatre, then, was perfectly situated to offer such an imaginative space: the metaphor of the nation as a world stage was also reversed so that the stage offered a view of the nation and the actor's bodies a view of its citizens. When reform hit the American stage, such as in The Drunkard, it showed audiences how to perform reform, which meant sympathizing with the victims of alcohol addiction and working to have this substance banned.

As we have already seen, abolitionist plays that portrayed slaves onstage were more problematic, for if the stage portrayed a nation and its people, what was the relationship between audiences and the non-white bodies represented onstage? Hartman answers this question by linking empathy to the erasure of identity for those who are enslaved, as into this void spectators merely place themselves and erase the other. Yet the very placelessness of slaves in this period of American history has long been documented, a fact that, I argue, unsettles Hartman's claim. Indeed, as Katherine McKittrick points out, "The racialization and ownership of space and place under slavery occurred across multiple scales, rendering a black sense of place virtually impossible under Eurocentric geographic arrangements" (103). ${ }^{23}$ Of course, cultural geographers like McKittrick are writing about real historical figures bearing the brunt of actual violence in specific geographic locations within the United States. What we find, however, when we look at plays like Uncle Tom's Cabin and The Octoroon, are performances that place audiences on 
uncertain footing when they sympathized with the enslaved characters onstage. Put differently, it makes more sense to describe "witnesses" to slavery onstage as being displaced in the stead of the other.

Consider the way that slavery functions in the works of Rowson, Tyler, and Bird, as discussed earlier. As I have shown, these works depict Americans who fall into slavery in foreign lands, but these enslaved characters nonetheless cling to their citizenship, consistently reminding audiences of their rightful place in the world, all the while exuding the burgeoning traits of the new republic. I would argue that this is true even, perhaps especially, in the case of The Gladiator, with Spartacus as the Jacksonian hero, and Edwin Forrest in the starring role, an actor who cultivated his own image to align with such heroic qualities. When slavery is depicted on American soil, however, sympathetic audiences put themselves in the place of characters without ties to any nation, and certainly without ties to the United States. In sympathizing with these "foreign" characters, audiences found themselves in a utopia of the worst kind, a no-place that unsettled their own shaky ties to a nation that was in the process of defining itself.

As it turns out, even within plays that relied on melodramatic sentiment to generate ticket sales, the content of the plays themselves often warned against these very reactions. While I have already illustrated the ways that Aiken's Uncle Tom's Cabin highlights the displaced lives of slaves in America, when revisiting the play we find a number of instances in which Aiken uses Stowe's dialog to challenge the possibility of sympathizing with these characters. Indeed, in the opening dialog between Eliza and George, the latter speaks past Eliza, and, I would argue, explicitly towards those in attendance. After Eliza implores George to remain faithful, George replies, "That's easy for people to say who are sitting on their sofas and riding in their carriages; but let them be where I am-I guess it would come some harder. I wish I could be good; but my 
heart burns and can't be reconciled. You couldn't, in my place [emphasis mine], you can't now, if I tell you all I've got to say; you don't know the whole yet" (376). This last line is worth pausing over, as George resists sympathetic responses on two different levels. First, audiences can't be placed in his stead because, as we have seen, the life of the slave is inherently displaced. Second, there is no way for George to articulate his experience, to tell audiences "all I've got to say," no way that they can know the whole story of a life in slavery. Though George takes an abolitionist position adopted often in print—one in which white freedom is set against the unimaginable plight of blacks — when spoken from the stage his statement, I argue, becomes a more nuanced articulation for something more than mere sympathy from those in attendance.

But what of those audience members who failed to heed this warning, those who may have come to the playhouse to experience the sentiments being described? In fact, these men and women might have seen themselves in the character of St. Clare who provides a model of sentiment at odds with George's espousals. One of the key comparisons made in the play is between St. Clare and his wife Ophelia. While at a point of religious crisis due to the death of young Eva, St. Clare comes across as a gentle man who tries to do right by his slaves. When St. Clare gives Topsy to Ophelia as a project for improvement, she treats the young girl quite harshly, much to the frustration of her husband. Speaking to Ophelia about Topsy, St. Clare tells his wife that, "Any mind that is capable of a real sorrow is capable of good" (418). The intersection of the culture of sentiment and abolitionism could hardly be summed up more concisely.

Nonetheless, the tension between displaced slaves and sympathetic audiences were only heightened by the elements of minstrelsy that run throughout. Minstrel performances were, after all, a kind of dramatization of regional displacement. By this I mean that minstrel shows 
succeeded primarily in the North, despite the fact that minstrel characters almost exclusively depicted slaves from the plantation South. ${ }^{24}$ Discussing the divide between actual plantation life and the depictions of plantation life on the minstrel stage, Eric Lott writes, "We might say that minstrel men visited not plantations but racially integrated theaters, taverns, neighborhoods, and waterfronts - and then attempted to recreate plantation scenes" (41). And yet minstrelsy, as described by Lott, often functioned at an even further remove. "Essentially using the plantation to gloss northern home and workplace relations," Lott writes, "the minstrel show witlessly though constantly and uniquely focused attention on the great conflicts of national life at midcentury" (170). Just as writers like Rowson, Tyler, and Bird found a safe haven for depicting slavery in foreign lands, minstrelsy found itself commenting on "northern home and workplace relations" through depictions of slaves in the American South. ${ }^{25}$

Looking back on the incredible success of Boucicault's plays, The New York Times in July of 1875 published a piece entitled "Recollections of a Theatre Goer" in which an unnamed writer describes several memorable scenes from Boucicault's broad range of plays. For this writer, The Octoroon "was one of the many picturesque sides of the great national sin...[that] had an enormous influence" ("Actors" 4). The scene re-imagined by the author is worth quoting at length:

Mrs. Allen, a very pretty woman, played the Octoroon in a most touching manner, and an old negro, one of the original minstrels, made a speech which was the embodiment of the pathetic. Never was seen a better piece of Southern life than the breakfast where the "Missus" serves out coffee, with three or four negroes running in and out with cups and saucers, upsetting each other, and generally confusing things while giving an air of hospitality and general helpfulness very cheering to the eye. Is [sic] was a great political 
and moral lesson, this play, and it had its effect among many other things in precipitating the war. ("Actors" 4)

It is as if the writer's discomfort with the "pathetic" plight of the "old negro" must be replaced in memory with a simple domestic scene, a bit of idealized "Southern life" that was "cheering to the eye." The horrors of slavery—like the identities of those who were enslaved—were thus displaced to make room for a "cheerful," stereotyped image of peaceful southern life. One imagines that the "great political and moral lesson" was lost not only on this writer, but also on countless sympathetic theatre-goers in antebellum America. 
Notes

${ }^{1}$ For Bird, this helped draw a line of succession from one great Republic (Rome) to, early Americans hoped, another (the United States).

${ }^{2}$ Despite being denied subjectivity, slaves did, of course, exercise subjectivity whenever possible. Take, for example, Harriet Jacobs's "loophole of retreat," a small space within a shed that Jacobs lived in for nearly seven years. While such a space was potentially insecure, it was nonetheless a bid for place in an otherwise placeless South. See Miranda A. Green-Barteet's “"The Loophole of Retreat': Interstitial Spaces in Harriet Jacobs's Incidents in the Life of a Slave Girl." Green Barteet argues that "Jacobs consciously positions the garret as a border space, one that exists betwixt and between other more clearly defined spaces" (53).

${ }^{3}$ Joseph Schopp contends that by keeping Moloc offstage until the end of the play, Rowson recodes "the traditionally male-dominated oriental space" (294).

${ }^{4}$ This claim would be echoed in later calls for equal rights, as blacks who fought in the Civil War should, some argued, be afforded the full rights of citizenship in the nation they helped create. As David Blight has shown, reunions and acts of remembrance in particular often stressed the crucial role of blacks in this struggle.

${ }^{5}$ It also ignores the conflicting roles many blacks played in the Revolutionary war, with thousands recruited by both Loyalists and Patriots to fight to either remain under British rule or for American independence, respectively.

${ }^{6}$ It should be noted that, according to Kritzer's reading, this empowerment of women carries over to the Algerian women who, in Rowson's play, find ways to help the captured American women. 
${ }^{7}$ Tyler's novel was published three years after the U.S. signed a peace treaty with Barbary, and at the time of publication no Americans were captive in Algiers.

${ }^{8}$ Perhaps surprisingly, some scholars argue that these captivity narratives, in the words of Elizabeth Maddock Dillon, are "concerned with more than a fantastic reversal of the racialized terms of U.S. slavery," instead emphasizing that these stories "addressed the emergence of the U.S. as a nation with global authority" (422). While Keri Holt makes more of the commentary on slavery in The Algerine Captive, she posits that the "wparts' of the nation... are not necessarily based on geopolitical borders" in the novel, as Tyler endorses a "federal pluralism" that is "produced by generating a more expansive critical perspective on the part of individual citizens, rather than by establishing a clearly delineated view of the nation's individual states" (492). Edward Larkin extends these arguments when he posits that novels like Tyler's "show how the politics and culture of the early U.S. were shaped not by a national story, but by an ongoing effort to combine nation and empire" (503).

${ }^{9}$ Even the most famous objectors, such as James Baldwin, find fault with Stowe's alleged racism, which, of course, does not make the book anti-abolitionist. Indeed, Baldwin seems as incensed by the "self-righteous, virtuous sentimentality" of Stowe's "very bad novel" as by the racist elements of the work (495-6).

${ }^{10}$ See Stephen Railton's immensely helpful website on Uncle Tom's Cabin in all its iterations at utc.iath.virginia.edu, hereafter cited in text as "Railton."

11 The racism in Stowe's abolitionist text can be seen as a larger trend in American letters which follow from Thomas Jefferson's Notes on the State of Virginia (1781) where racism abounds in his arguments for emancipation. 
${ }^{12}$ Richards seems here to be referencing the multitude of minstrel shows that were exceedingly popular during this period, and not necessarily referring to Uncle Tom's Cabin.

${ }^{13}$ Others, like David Grimsted, comment on Aiken's additions and subtractions to Stowe's novelistic plot. The scenes added by Aiken, Grimsted argues, tend towards the comic, and he deleted complex characters in a move that "diminishes the complexity of her [Stowe's] discussion of slavery" (236).

${ }^{14}$ McConachie finds this to be the case in both Aiken's and Conway's versions of Uncle Tom's Cabin.

${ }^{15}$ We might also take into account the shifting nature and definition of "popular" in the nineteenth century. For instance, as Lawrence Levine argues, Shakespeare's plays were decidedly popular (as opposed to "high-brow") during this period.

${ }^{16}$ Scudder is a genial but complicit in the slave trade of the play, and, as Jeffrey Richards points out, it is Scudder who "enunciates the doctrine of white dominance that underlies all the action" ("The Octoroon" 446).

${ }^{17}$ Wald uses Freud's notion of the uncanny to help us see "what inaugurates narratives of identity and what haunts them," where "something 'known of old and long familiar"' becomes "something frightening" (5).

${ }^{18}$ Aiken draws here from volume 1 chapter 3 of Stowe's novel (Stowe 13).

${ }^{19}$ Lifted by Aiken from volume 1 chapter 11 (Stowe 97).

${ }^{20}$ Lifted by Aiken from volume 2 chapter 20 (Stowe 209).

${ }^{21}$ For the rest of this chapter, I will use the term "sympathy" rather than "empathy."

${ }^{22}$ Regulating sentiment was hardly a new concern, as evidenced by the previously quoted 
preface to Rowson's Slaves in Algiers. However, the abolition movement offered new opportunities to engage in the policing of sentiment.

${ }^{23}$ McKittrick expands on this notion in an essay with Clyde Woods, where they write that, "A Black sense of place and black geographic knowledges are both undermined by hegemonic spatial practices (of, say, segregation and neglect) and seemingly unavailable as a worldview" (7).

${ }^{24}$ Eric Lott suggests that minstrelsy failed to reach the levels of popularity that it did in the Northern states because many Southern cities banned this style of performance as the issue of slavery became more controversial in the 1850 s (38).

${ }^{25}$ See also Coleman Hutchison's Apples and Ashes: Literature, Nationalism, and the Confederate States of America for a discussion of "Dixie," an 1859 minstrel show appropriated by the North after the Civil War. Hutchison argues that "the people of both the United and Confederate States of America used 'Dixie' to manage the existence of competing nationalisms" (145). 


\section{Chapter Four: The One-Man Show as Counter-Performance: William Wells Brown's The Escape and the Segregation of Dramatic Space}

On July 7, 1856, William Wells Brown made a stop on his lecture tour in Vergennes, Vermont where he spoke on the ills of slavery and the importance of abolition in the United States. An unnamed reviewer for the Vergennes Citizen writes:

Seldom have we listened to a lecture by a white man surpassing it in interest, eloquence, and feeling. Mr. Brown's appearance as a lecturer is rather prepossessing although you feel better prepared to listen to a narrative than a lecture, and it is not until he warms up with the theme that you lose sight of the speaker, and flashes of wit and sparkling gems of thought scattered with rapidity and force convince you that no ordinary man is swaying the feelings of the deeply interested and breathless auditory. (qtd. in Farrison 281-2)

After offering a backhanded compliment (Brown's performance is better than most lectures by white men) the author claims that the audience was so enamored with the speech as to "lose sight of the speaker." What does it mean to "lose sight" of a black man during a lecture, especially in a review that compares Brown's speech to lectures by white men, a contrast that highlights Brown's status as a black man in antebellum America?

This reviewer's lack of descriptive clarity might be forgiven, for to a great extent we are still wrestling with William Wells Brown as an historical figure who resists easy description. As a mixed race former slave whose work often interweaves autobiography and fiction without clearly distinguishing between the two, Brown's authorial voice is distinctive for its constant evolution. At the same time, this constantly evolving voice can be maddening for scholars who wish to paint a coherent picture of Brown's life. 
Indeed, the same newspaper that described Brown's vanishing act during an abolition speech noted his incredible presence as he took command of an audience one night later. After a July 8 performance of The Escape; or, A Leap for Freedom, a play that would soon become the first published drama by a black writer in America, the reviewer describes Brown's adoption of multiple, competing personas, "especially in the last act when the trembling fugitive burst forth into a peroration towering and noble in language and sentiment in favor of freedom as it SHOULD be" (qtd. in Farrison 282). The writer's language is unintentionally revealing. The Escape, according to this reviewer, merges two strands of Brown's own identity, "the trembling fugitive" and the powerful "noble" public figure fighting for abolition. Rather than receding from view as in his standard lecture, the dramatic performance allows Brown to embody various competing, shifting forms without permitting audiences to lose sight of the performer himself.

These nightly transformations took place not in the antebellum theatre, but rather in lecture halls, courthouses, and churches in New England. It is, perhaps, easy to overlook just how radical Brown's decision to perform in the lecture hall was in antebellum America. In effect, Brown reversed conventions of two seemingly distinct genres: lecture and dramatic performance. In the former, the lecturer's presence is necessarily heightened, as their personal or professional ethos helps validate the informational and emotional content of the lecture. Audiences attended lectures by Brown or Frederick Douglass, for instance, in large measure because of their respective experiences as former slaves. In a dramatic performance, conversely, the performer's skill is measured by their ability to blur the lines between the actor's persona and the fictional persona of the character being portrayed. Starring in Metamora (1829), Edwin Forrest adopted the role of Napoleonic hero so fully that audiences found it difficult to separate the man from his theatrical role (McConachie 91). By reversing these conventions, Brown 
resisted audience expectations, as evidenced by the marked contrast drawn by the editorialist above, who found Brown fading from view in his lectures while refusing to disappear into his various roles in The Escape. "Theatre culture," writes Rosemarie Bank, "provides a way to see antebellum destabilization and change in other than binary or hegemonic terms, to regard it as a performance involving a variety of relationships and dynamics rather than a structure," but Brown's lecture performances push back against those who view the theatre as the only site for destabilization and change (165). For Brown, the dramatic form represented an efficient means of giving voice to highly charged political statements, but his lecture performances opened up the possibility that political performance could leave the physical theatre behind.

This radical claim flies in the face of the scant scholarly attention paid to Brown's dramatic works. The Escape holds the dual distinction of being both Brown's least studied work and, on the surface, the least inventive, least experimental addition to his oeuvre. Even those scholars who have helped rejuvenate Brown as an important author and reformer have struggled to locate his dramatic works within the context of his novels and nonfiction. In the words of Brown's biographer, William Edward Farrison, "By the time Brown wrote The Escape, the subject matter of which he composed it had become so familiar and indeed so stereotyped that it needed a newer and more original treatment than he gave it" (303). Yet as the aforementioned newspaper reviews suggest, Brown's dramatic performances thrilled audiences with their mix of melodramatic entertainment and antislavery argument.

It seems clear, then, that there was something decidedly provocative and new in Brown's performances, something that distinguishes the "familiar" printed melodrama from Brown's enactments. In this chapter I argue that by delivering his play as part of a lecture tour, and by performing in churches and courthouses, Brown implicitly questions the political efficacy of the 
antebellum theatre. Yet even as Brown rejected the theatre as a site for change, he used the often rigid constraints of the melodramatic form - the most popular theatrical entertainment of his day — as a tool for exposing the limitations of the stage. Put differently, by recapturing the phenomenological elements of a performance outside the theatre proper-such as in churches and courthouses — we find that Brown's performance is as much about what it isn't (a traditionally staged drama) as about what it is (a counter-performance through the medium of the one-man show). In short, Brown adapts sites of performance, repurposes the lecture tour for dramatic readings, and, above all, collapses a standard drama into a one-man performance.

I will suggest that through both the mode and sites of performance, Brown troubles a common feature of antebellum melodramas, in which black and white spaces are segregated due to the practical restrictions of the stage and norms of theatrical culture. Antebellum melodrama tended to segregate black and white spaces onstage, and spectators were similarly segregated based on race (as well as class). In popular performances such as Uncle Tom's Cabin, theatrical space was clearly marked for audiences as either white (i.e. a master's dining room) or black (i.e. the bare slave quarters) with relatively few integrated spaces. In Brown's monodrama, on the other hand, he took on the roles of whites and blacks alike, effectively de-segregating the performance space within buildings that lent religious and legislative weight to his abolitionist agenda. Finally, Brown achieves something that stage melodramas could not: by performing as master and slave he offered audiences a representation of miscegenation. Audiences were thus confronted with the sexual violence intrinsic to slavery in the form of a man who stood before them as a result of this very act of violence.

\section{William Wells Brown and Textual Performativity}


To better understand The Escape as a document and as a performance, we must first place it within the wider context of Brown's life and work, though locating a coherent narrative of Brown's life is a task fraught with inconsistent "facts" and skillful fictions. Over the course of his life, Brown told multiple, competing stories about his own lineage and role as a slave in the South, "asserting in some places that he was the grandson of Daniel Boone, describing in others how he unwittingly participated in the power structure of slavery, and detailing in still others his subversive relation to the slave owners" (Levine 4). These shifting, competing autobiographical narratives that he repeated throughout his life often alluded to his mixed-race status. Brown emphasized "the sexual and familial violations that were common under slavery" as a means of questioning "the stability of the color line that limited Brown's rights and activities as an American” (Earnest, Introduction, xxiv). Brown’s coyness regarding his personal and familial history are complicated further by the fact that, as William Edward Farrison makes clear in the opening lines of his biography, "The ancestry of William Wells Brown, like that of the vast majority of others who were born into American slavery, has been almost lost to history" (3). Turning this unfortunate fact on its head, Brown used such ambiguities to craft a public persona in the trickster tradition, giving himself credence to construct his own identity while pushing back against those who would define him in any singular way. ${ }^{1}$

Despite the rich opportunities for critical study in his work, Brown's writing was largely ignored until relatively recently. The recuperation of Brown as a writer worthy of critical study is due in no small measure to a reevaluation of the radical narrative techniques found in most of his fictional works. In his most often studied novel, Clotel (first published in 1853), Brown lifts the work of others in a kind of literary pastiche, which allows him to appropriate "the texts of a culture that steals black bodies" (Levine 6). ${ }^{2}$ But in the novel's opening chapter Brown also 
revisits his path to freedom through a third person account that makes explicit reference to his own previously published Narrative of William W. Brown (1847). Making matters even more complicated, Brown catered to different audiences by making crucial revisions to Clotel. For instance, the British edition of the novel makes explicit that the title character is Thomas Jefferson's illegitimate offspring, but in the last American edition Jefferson isn't mentioned by name, a revision that turns "a clear and specific condemnation of the hypocrisy of the founding fathers of the United States into a more general statement on the virtues of defending morality and truth" (Schell 50). ${ }^{3}$

Though Clotel has garnered the most critical attention for resisting generic boundaries, more recently scholars have located a similar aesthetic in Brown's later works, such as the quasinovel My Southern Home (1880), which John Ernest calls “Brown’s most interesting and challenging text" ("William" 88). Where in Clotel Brown sets his own voice against other voices from antebellum publications, in My Southern Home he blends essayist commentary, folk songs, and even dramatic texts in a construction that anticipates post-modern techniques. If, as Robert Levine points out, it is instructive to consider Brown "as a kind of plagiarist," Brown's corpus resists even this description both due to the anachronism of the term, and because Brown's novels, plays, and speeches tend to fold back in on themselves as versions of an $u r$-text rather than distinct literary pieces. As such, Brown may be a forerunner of what William Andrews calls the "most radical vocal experiment in nineteenth-century black American writing, that which introduced the fictive voice into the tradition of African American narrative" (24). In the process, Brown questions the usefulness of these oversimplified binaries (fiction, nonfiction) in the first place.

Brown's radical narrative techniques both subvert and entertain, leading many scholars to 
describe his texts as "performative." For instance, Jennifer Schell argues that in Clotel Brown "performs the South—its landscapes, its demography, its histories, its laws, its people—for his audiences,... [as he] strategically represents different versions of the South and its history in each version of his Clotel novels" (48). John Ernest, commenting more broadly on Brown's works, finds that "for Brown... literary genres were less conventions to be followed or even reshaped than they were codes of cultural authority and modes of performance" (Liberation 334). In short, much of the critical work on William Wells Brown tends to use "performance" as a descriptor for various kinds of narrative experimentation.

I would like to suggest, however, that while using the idea of performance helps us compartmentalize texts that otherwise resist definitional boundaries, this line of inquiry tends to discount Brown's more literal links to performance as the first black playwright in the U.S. Once returned from his European lecture tour, in 1856 he wrote his first play, Experience, or, How to Give a Northern Man a Backbone, a satire of the Reverend Dr. Nehemiah Adams' A South-Side View of Slavery. In the latter, Adams describes his trip through the American South, arguing that, "Instead of regarding the south as holding their fellow-men in cruel bondage, let us consider whether we may not think of them as the guardians, educators, and saviors of the African race in this country" (141). ${ }^{4}$ Though Brown's play was likely never published, local advertisements for his readings hint at the satirical treatment of Adams's text, with Brown's play following a pastor who visits the South, only to be sold into slavery. The play seems to have concluded with the author revising his views on slavery following his no doubt harrowing ordeal (Ernest, "Introduction," ix).

It makes a great deal of sense for Brown to use the idea of the stage given the rapid rise in popularity of the American theatre. Taking as her subject Romantic drama, Melynda Nuss 
pinpoints a number of British writers who, as theatres expanded in size to meet increased demand, "imagined impossible theatres - theatres that preserved old notions of theatrical and coterie intimacy while gaining the reach of mass distribution" (4). It is necessary, though, to locate Brown's own imagined theatre in the context of American theatre history. Odai Johnson argues that in the mid-eighteenth century, the "permanent, purpose-built theatre" often stood empty after itinerant acting companies left town, but "even in the company's absence the empty playhouse kept the idea of theatre alive, like the publication of plays created audiences through readership" $(24,46)$. Following Johnson's line of thought, a key reason that the theatre flourished in antebellum American can be found in the solid playhouse structures which signaled the staying-power of theatrical entertainment in the new nation. ${ }^{5}$

A century later, Brown turned this aspect of theatrical history on its head as he divorced the idea of theatrical performance from the playhouse and implicitly questioned the political efficacy of the theatre. If it is true, as Marvin Carlson argues, that "the entire theatre, its audience arrangements, its other public spaces, its physical appearance, even its location with a city, are all important elements of the process by which an audience makes meaning of its experience," the fact that Brown primarily performed the play in churches and courthouses is revealing (2). Though the courthouse and church were certainly sites of performance, they were sites of performance with greater stakes: one's salvation (either religious or political) was purchased within these public buildings. Brown could thereby lend his own performance more weight, just as he gained a certain gravity by reading the play while traveling on his lecture tour.

It is worth pausing to note the significant overlap between Brown's work as an antislavery (and temperance movement) lecturer and this foray into dramatic performance. Indeed, we might locate a necessary precursor for Brown's dramatic aspirations in his performances as a 
traveling lecturer for the Western New York Anti-Slavery Society in 1843 (Farrison 81). As Brown gained notoriety for his anti-slavery lectures, he toured throughout New England, and on July 18,1849 , he sailed to Liverpool to continue his lectures in Great Britain and Europe (Farrison 140-5). ${ }^{6}$ The element of performance in such lectures is suggested in a description published in the August 9, 1850 edition of the Liberator: "Mr. Brown made a long and eloquent address, exhibiting some of the hideous features of slavery, and at the close of it sung a fugitive slave song." The writer goes on to describe "the quaint style in which this was sung, to the tune of one of the old favorite Negro melodies," which "elicited roars of laughter and loud cheering, and Mr. Brown was compelled, by the calls of the audience, to repeat it" ("American" 126). Just as Brown's written works drew upon multiple, sometimes competing genres, so too did his lectures, which paired solemn descriptions of slave life with songs that roused audiences into demands for an encore. ${ }^{7}$

Audiences may have responded in such a manner not only because Brown's lectures mixed in elements of performance (i.e. song) but also because his lectures and dramatic readings of Experience often shared venues. ${ }^{8}$ As Brown turned more and more of his attention to dramatic readings instead of lectures, he nonetheless performed in spaces more associated with the latter than the former. In March and April of 1857 he read Experience in courthouses and churches in Elyria, Ohio, and in November he performed for the Salem Female Anti-Slavery Society in Lyceum Hall (Farrison 284). According to an advertisement in the Liberator on April 25, 1857 Brown read Experience at a time concurrent with the New England Anti-Slavery Convention held annually in the last week of May (qtd. in Farrison 278). It seems reasonable to conjecture, then, that Brown used his prominence on the lecture circuit to draw crowds for his dramatic readings. ${ }^{9}$ These crowds would only grow as Brown performed his next drama, The Escape. 


\section{Dramatic Text as Counter-Narrative}

Brown had a practical reason for shifting from lecturing to dramatic readings for, as he stated baldly in a letter to Marius Robinson, editor of the Anti-Slavery Bugle, "People will pay to hear the Drama...that would not give a cent in an anti-slavery meeting" (qtd. in Farrison 293). His readings of The Escape were so successful that, in 1858, he published the play. As his “Author's Preface” implies, however, the printed play could not be so easily disassociated from Brown's dramatic readings. Brown warns his readers that he "never aspired to be a dramatist," and "if it is not readable, no word of mine can make it so," claiming that "this play was written for my own amusement, and not with the remotest thought that it would ever be seen by the public eye" (3). On the one hand, this note could be read as a standard apology for the text, a fairly prevalent trope of the day, meant more to evoke polite modesty than to admit any actual flaws in his text.

On the other hand, Brown entered uncharted territory with the first published drama by a black writer in the U.S., though he was far from the first professional black performer. In the early nineteenth century black theatre began to carve out its own place on the theatrical scene, most notably in William Brown's (no relation) African Company. As Marvin McAllister argues, black productions like those put on by the African Company "fully realized and perhaps even reconciled the multiple experiences of early national African Americans" through productions of, most notably, “blackened" Shakespeare (104). ${ }^{10}$ William Brown's decision to stage Shakespeare with black actors afforded the African Company the cultural capital of a "revered writer" while challenging "absolute racial ideologies" (McAllister 142). William Wells Brown uses Shakespeare in similar fashion by quoting from Hamlet in the epigraph to The Escape: "Look on 
this picture, and on this." By including this reference Brown insists "that his readers read his drama through the framework of Shakespeare's plays (particularly Hamlet)...tapping into a cultural literacy that was available to all Americans no matter their color" (Botelho 193). Put differently, this epigraph links Shakespeare, black productions of Shakespeare, and Brown's own foray into the world of dramatic publication. ${ }^{11}$

The Escape, a melodrama, follows two slaves, Glen and Melinda, who wish to marry but are not permitted by their owners, Dr. and Mrs. Gaines. Cato, another slave character, works as Dr. Gaines's medical assistant and provides much of the comic relief of the play. Mrs. Gaines hopes that her slave, Hannah, will marry Cato, but the young woman resists as she considers herself married to Sam, a slave who has been sold away. Dr. Gaines takes on the role of melodramatic villain, striving to make Melinda his mistress by hiding the young woman at Poplar Farm, and Mrs. Gaines plays the role of unhappy wife, pining for Reverend Pinchen while discovering her husband's secret hidden nearby. ${ }^{12}$ When Glen and Melinda flee to the North to be married, Dr. Gaines and Cato chase them. Cato ultimately joins Glen and Melinda and the play ends as all three escape by ferry to Canada.

As the first of its kind, The Escape tells a story that was hardly revolutionary or even particularly new, for as John Ernest points out in his introduction to the play, Brown offers a "recontextualization and a significant rearrangement of established literary conventions and familiar antislavery commentary" (xi). Indeed, one of the most lasting images from the play, that of Cato attempting to extract the tooth of another slave, had previously appeared in narrative form in Clotel, was transcribed verbatim in The Escape, and was later inserted in chapter three of My Southern Home. Repurposing this scene enabled Brown to "question both textual and racial authenticity," but it also highlights Brown's reliance on stock plots and characters (Ernest, 


\section{Liberation, 86).}

As, on the surface, Brown's most generically conventional text, The Escape begs an important question: why did Brown choose to tell a stock story of the evils of slavery through the dramatic mode? For Ernest, to my knowledge the only scholar who has ventured an answer to this question, "the dramatic mode enables Brown to emphasize the cultural forces behind the conventions and to emphasize as well the extent to which identity is a performance on the cultural stage," through a cast of characters, almost all of whom "are involved in a deceptive performance of selfhood, the playing out of a culturally assigned role to veil private motivations" ("Reconstruction" 1110). The usefulness of this reading lies primarily in its ability to tie The Escape to Brown's other texts, and to reaffirm Brown's interest in performance, both textual and cultural.

At the edges of Ernest's admittedly persuasive argument is Brown's curious decision to perform his play not in a playhouse, but rather on his lecture tour. After all, as we have seen, Brown may have been the first black playwright, but black theatre was finding its own provisional success at this time, especially in New England. The Escape's antislavery message may be pointed to as a reason for keeping it on the reform lecture circuit rather than the stage proper, but the play's dramatic features align quite nicely with other staged plays from the period, most notably the various renditions of Uncle Tom's Cabin and Dion Boucicault's The Octoroon. In short, were The Escape put onstage, it would have joined a host of other plays that used the melodramatic mode to dramatize relations between whites and blacks, slaves and masters in antebellum America.

The published text of the play, though, highlights Brown's interest in crafting a counternarrative capable of both subscribing to and subverting generic conventions. This is evident even 
before the play proper begins, in Brown's “Author's Preface.” Attaching an author's preface to a dramatic publication was fairly standard procedure in the period between the Revolutionary and Civil Wars. The preface to James Nelson Barker's The Indian Princess (1808), for instance, aims to bring the "genius" of American theatre out from beneath the long shadow of Shakespeare while the preface to Mary Carr's The Fair Americans: A Play of the War of 1812 (1815) similarly asks, “Could you, capricious, thro' proud Europe roam / In search of genius, which you slight at home" (185). Prefaces to Susanna Rowson's Slaves in Algiers; or, A Struggle for Freedom (1794), William Henry Smith's The Drunkard (1844) and Anna Cora Mowatt's Fashion; or Life in New York (1845), serve primarily as promotional tracts, intended to catch the attention of readers who may have missed out on these respective theatrical productions. ${ }^{13}$

Within his opening gambit, though, Brown finds a number of ways to resist the generic conventions of the author's note:

The main features in the Drama are true. GLEN and MELINDA are actual characters, and still reside in Canada. Many of the incidents were drawn from my own experience of eighteen years at the South. The marriage ceremony, as performed in the second act, is still adhered to in many of the Southern States, especially in the farming districts.

\section{(Escape 3)}

Brown thus makes the claim that his protagonists, Glen and Melinda, are "actual characters," a curious phrase that contains its own contradiction as it combines the (f)actual and the literary ("characters"). Not content to blur distinctions between fact and fiction, Brown also locates his protagonists outside of time, noting that they "still reside in Canada." Finally, Brown concludes his preface with an authorial apology turned on its head, as he admits "the play, no doubt, abounds in defects, but as I was born in slavery, and never had a day's schooling in my life, I 
owe the public no apology for errors" (Escape 3).

Brown's style here is meant to provoke readers, and it seems far more overtly political than, for instance, the preface to Clotel. In the latter work, Brown follows a truncated argument against the "professed Christians" who have slowed the abolishment of slavery with a more muted apology:

If the incidents set forth in the following pages should add anything new to the information already given to the Public through similar publications, and should thereby aid in bringing British influence to bear upon American slavery, the main object for which this work was written will have been accomplished.

No such concern for literary manners can be found in the preface to The Escape with its disdain for the unsympathetic reader. And yet, as Trish Loughran argues, in his novel Brown "delink[s] individual identity both from the body (as either raced or gendered) and from location in space," and this choice takes Brown "first (geographically) to England... and then, in Clotel, to the scene of American origins" (405). Consequently, we might locate in Brown's preface to The Escape a continuation of a project, both literary and lived, which dates back at least to his most often studied work.

Brown's preface asks us to look through the standard melodramatic tropes of The Escape, past the standard dramatic text that it became when published, to find instead the traces of a performance that was anything but traditional. While it is certainly possible to read too much into this author's preface, I argue that it sets the stage, so to speak, for Brown's delivery of the play.

\section{Brown's One-Man Show as Counter-Performance}

As a man well-connected in literary and political circles, Brown almost certainly could 
have had the play produced for the stage. Nor was he unaccustomed to the professional playhouse. According to William Farrison, Brown "had read a considerable number of dramas, including many of Shakespeare's, and he had seen many plays on the stage in both America and Great Britain" (279). Despite Brown's exposure to a wide variety of staged drama and his aforementioned desire to tap into the profits resulting from these performances, there is no evidence that he intended for this play to be performed by anyone other than himself. In the absence of such evidence, I want to suggest that we can reach some reasonable conclusions as to what The Escape achieved on the lecture circuit and what this performance gained by never entering the playhouse.

One possible explanation lies in the inherent conservatism of the early American theatre. As Heather Nathans argues, theatres in Boston, New York, and Philadelphia were built in the late eighteenth-century as material evidence of 'a 'democracy of glee'—sites for reconciliation, not confrontation, [with colonists] failing to realize that the formulation of national identity, or a national cultural product, would be an ongoing and negotiated process" (171). The abundance of British dramas and the tendency of early American playwrights to mimic British plays speak to a persistent conservatism that lasted well into the nineteenth century, for the imperative of early American theatre was to "do the new only when it reminds of the old" (Richards, Drama, 29). As America moved closer to the Civil War, this conservatism was, if anything, only more pronounced. "Divided by class, education, politics, race, nationality—but most importantly by social behavior," writes Karl Kippola, "urban audiences patronized theatres that catered to their niche and demanded entertainments and stars that reflected their values" (4). More subversive performances, such as the "blackened" Shakespeare of William Brown were met with riots both in and around the African Theatre, and the subsequent assault of the producer William Brown 
highlights the resistance to less conservative forms of theatre, particularly when these performances dramatized race relations (McAllister 137-50).

The antebellum lecture circuit also offered Brown a level of dramatic mobility not afforded by the stage in the 1850 s. Prior to 1760 , the American theatre was far more transient than in Brown's time, with few permanent playhouses. Actors were subsequently referred to as "strollers" and early playing groups often operated under the moniker of "fugitive companies," playing in one location and leaving for the next town after the performance (Johnson 24). In many cases, the theatrical space reflected a palimpsest of previous, non-theatrical uses. William Dunlap offers the old Dutch church in Chatham-row as a suitable example in his History of the American Theatre. "This little portion of the globe (the site of the church)," writes Dunlap, "had been used and abused as a play-house, a church, a riding-school, and a prison, all within the space of one-fourth of a century" (48). As the eighteenth-century progressed, however, American cities and towns began to model their public spaces on European models, and they built playhouses that took on the status of the "English garden, as a sine qua non of polite English culture" (Johnson 55). By the mid-1850s, the playhouse had become an entrenched part of city life in New York, Philadelphia, Boston, and a host of other locations on the east coast. With this rise in more permanent theatre structures, American drama put down more resilient roots and shed some, though certainly not all, of its itinerant qualities.

At the same time that the playhouse was putting down these roots, former slaves like Brown reflected on their newfound freedom to travel. According to Stephen Lucasi, "Just as literacy stood as a liberating disobedience in many narratives, travel is, for Brown and other narrators of the period, the essential transgression of and emancipation from the laws of bondage" (521). Brown's works, from his narratives of early life to later works like Three Years 
in Europe; or, Places I Have Seen and People I Have Met (1852), show readers that "representations of fugitive travel can disrupt the familiar plantation-based accounts of slavery" (Lucasi 528). By traveling through Europe as a "fugitive tourist" and by chronicling this period in his life, Brown introduced "a new kind of mobility to African American literature-a mobility that is profoundly different from the forced movements of the middle passage and the domestic slave trade, and different too from the 'covert geographies' of flight and escape mapped out by conventional slave narratives," including his own (Baraw 454). The lecture circuit, too, enabled Brown to perform his own mobility, and this mobility was further emphasized when the play being performed centered on escape.

Brown's interest in performing mobility predates The Escape. In his Panoramic Views, a fascinating mix of history and performance that is woefully understudied by scholars, Brown tapped into a popular form that reached its pinnacle in America in $1848 .{ }^{14}$ In 1847 , Brown saw John Banvard's immensely popular Mississippi from the Mouth of the Missouri to New Orleans, in which views of the Mississippi were unreeled for an audience while a commentator described the scene at hand (Costola 19). ${ }^{15}$ These scenes of the Mississippi contained representations of slavery, though the depictions upheld a "proslavery bias" through an "obviously partial view of a celebrated American landscape" (Baraw 453).

A representative panorama from Brown's performance of Panoramic Views showed audiences a seemingly mild scene of plantation slavery unrolled across the stage, but rather than allow those in the audience to look past the laboring slaves, he instead forced them to confront the horrors of slavery through a combination of static tableau and these words spoken onstage. The first paragraph presents a scene such as would have been seen in Banvard's scrolling canvas: The Slaves in this view now before us are at work in a Virginia tobacco-field. The man 
on horseback is a Slave-dealer; probably, the agent of one of the wholesale dealers in Washington. The man standing by him, is the owner of the farm. Here we see Slavery in its mildest form; there being no overseer or driver. The master merely gives out the task to the slaves, and leaves them to do their work, or goes occasionally into the field and looks after them.

Notice the shift in what follows, as Brown redirects the audiences' gaze from Banvard's romanticized plantation to a more realistic depiction of the ways that slavery disrupts domestic life:

You will observe, by the way in which the Slaves before you watch the Slave-trader, that they fear he may succeed in purchasing some of them from their present owner.

Whatever may be said of the good treatment of Slaves in those States where it exists in its mildest form, the continual fear of being sold and separated from their nearest and dearest friends, makes it bad at best. (qtd. in Costola 24-5)

In The Escape, Mr. White tells a begging man, "Will you hold your tongue? You've spoiled some of the finest pictures in the world. Don't you see that I am sketching?" (46). In both this play and his moving panoramas, Brown seems to be attempting just this feat, to "spoil" the distorted (and white) images of bondage that help perpetuate legal enslavement.

The moving panorama also "allowed for an experience that would soon become a reality with the development of the railroad in the United States," and so Brown took audiences on a tour that re-oriented how the audience viewed the plantation South (Costola 20). Perhaps just as important, during the panoramic performances Brown played the role of conductor, controlling both the unscrolling canvas and the accompanying orations and making meaning in the critical distance between word and image. "Travel is increasing / Build a double track" Cato/Brown 
sings at the end of The Escape in a song that conflates railroads both "underground" and industrial.

It seems probable that Brown's interest and background in panoramas informs the construction of The Escape as its own kind of counter performance. Brown achieves his most politically charged dramatic moments in the play by juxtaposing seemingly contradictory characteristics within individual characters, a move not unlike the juxtaposition of spoken word and image in his panorama. This dramatic strategy comes, for instance, in the form of Mrs. Gaines, who interrupts a discussion with Reverend Pinchen to threaten Hannah, a slave girl: "Hannah, what are you standing there listening for, and neglecting your work? Never mind, my lady, I'll whip you well. [Aside] Come, do go on, brother Pinchen, with your godly conversation. It is so sweet! It draws me nearer and nearer to the Lord's side” (13). Setting Mrs. Gaines's threats of physical violence alongside her sexual desire for the Reverend and her hope for salvation stresses the shaky foundations of all ideologies involved: slavery, marriage, and the hypocritical (white) Christianity attacked by writers like Brown and Frederick Douglass.

Brown also uses Cato, his most complex character, to highlight these juxtapositions. When Dr. Gaines puts on airs after "earning" a promotion, he instructs his wife to "call me Colonel, my dear." Gaines interprets his good fortune as a sign that "Providence had designed me for something great," and the audience is meant to laugh at a man who esteems himself so highly (21). When, however, a few lines later Cato is spurned by Tapioca in favor of "a common, ugly lookin' cuss like Big Jim" instead of a "suspectable man like me," we find ourselves on less sure footing. Later in the play Cato sings: "Now haste all bondmen, let us go, / And leave this Christian country, Oh; / God help us to Victoria's shore, / Where we are free and slaves no more!" only to placate Mrs. Gaines in the next breath, telling her, "I allers dose what you and 
massa tells me, an' axes nobody" (25).

\section{Phenomenology of the One-Man Show: Melodrama as Monodrama}

And yet, the dramatic text of The Escape contains only subtle signs that Brown performed all the roles himself. For instance, rather than listing a "cast of characters," Brown's play begins with a list of "characters represented," a seemingly minor shift that nonetheless emphasizes the referentiality of performance. More often the dramatic text reads like any number of dramas from the period. Throughout we're given very specific stage directions with characters not only entering and exiting scenes, but prescriptions for characters to enter and exit "L." or "R." To be sure, these spatial cues help the reader to imagine the scene, but pinning down how (or if) Brown verbalized these cues remains a difficult task. Writing in The Liberator, Henry C. Wright describes Brown's audience as "listen[ing] to his reading—or, rather, reciting — with deepest interest, and the only regret seemed to be, that it was too short, though the delivery of it occupied an hour and a quarter" (163). Wright's amended description of the performance as both a reading and a reciting reflects a reviewer struggling to fit an alternative mode of performance into more popular forms of presentation. This hesitance leads me to believe that it was at least possible that Brown recited his play verbatim, including the stage directions printed in the published document.

Whether or not Brown read these directions during his performance, without question he relied on the idea of the stage in a number of different ways. Perhaps most obviously, Brown tapped into one of the most popular forms of theatrical entertainment: melodrama. The decision to write a melodrama could be explained by its popularity, but to do so misses the more subversive elements of Brown's decision to utilize what turns out to be an unlikely choice of 
genre. According to Jeffrey Mason, melodrama doesn't simply offer us clear heroes and villains, it also attempts "to encompass the entire American experience by reducing it into stageable terms" (198). It is worth pausing to consider what this might mean for Brown, a man who believed that "slavery never has been represented; Slavery never can be represented" (qtd. in Ernest, Introduction, xxxi). To put it mildly, Brown's beliefs regarding representation and melodrama's inclination to represent holistically are at odds with one another.

Pairing Brown's text with a phenomenological discussion of the play, though, helps us to reconcile his skepticism regarding representation and his decision to write and perform a melodrama. As Stanton Garner points out, "The dramatic text...is a valuable means of access to the stage in particular phenomenological configurations" (5). A careful reading of the play highlights a practical reason for performing a melodrama. Melodramas have long been disparaged by critics for relying on less-than-artful soliloquys: plaintive characters convey emotion and provide backstory by speaking out into space (or directly to the audience). As it turns out, Brown used this generic feature to his own advantage. For example, Melinda's long soliloquy in act 1 engages the audience's sympathy as she expresses her "fear that Glen will be separated from me, for there is nothing too base and mean for master to do, for the purpose of getting me entirely in his power" (11). Later in the play, Melinda makes a similar point as she emotes, "What a curse slavery is! It separates husbands from their wives, and tears mothers from their helpless offspring, and blights all our hopes for this world" (33).

Soliloquys like Melinda's, then, not only allowed Brown to forward the narrative of the drama, but also to emphasize themes that he wouldn't have wanted his audience to miss, such as the perilous state of the family unit in slavery and the constant threat of sexual abuse at the hands of white masters. These are the rare moments when Brown could represent a single character 
onstage as opposed to the myriad moments when he performed — or "recited"- the dialogue of multiple characters, possibly interspersed with stage directions. Even in the more dialogue-heavy scenes, Brown relies on the melodramatic tendency to narrate a scene, as when Walker tells Sam, “Don't you and Sally cry. I am of tender heart, and it allers makes me feel bad to see people cryin"” (20). In a scene where Sam isn't given the opportunity to respond to Walker's demands, and with Brown only able to adopt the voice of one character at a time, such descriptions nonetheless allow for a kind of dramatic back-and-forth.

That Brown performed these back-and-forth scenes alone heightens the curiousness inherent in a former slave playing the roles of men and women, masters and slaves, Northerners and Southerners. The relatively scant scholarship on The Escape tends to focus on the way these performative transformations illuminate the performance at the heart of all associations of identity. As John Ernest puts it, “Brown's performance of identity on the antislavery lecture circuit became a commentary on performance itself that included a critique of the stage on which he stood even as he extended that stage to include the audience in the performance"

("Reconstruction" 1118). One notes in such a statement, though, the tendency to ignore the ways that Brown's spatial politics come to bear on the admittedly clear identity politics in his performance. That is, to argue that Brown "critique[d] the stage on which he stood" without taking stock of the fact that his performances were decidedly un-staged opens up a considerable area of further inquiry. It is here, within this concept of the un-staged that I'd like to pursue a final line of thought. What did Brown gain by performing a monodrama outside the theatre proper?

Answering this question requires that we take note of the spatial orientations of antebellum melodramas that did take place in the playhouse. Until the mid-1850s, American 
theaters were divided into three seating areas: the pit, box seats, and the gallery, with blacks not permitted in the latter two sections (Botelho 197). If audiences were segregated in the theatre, the para-performances that accompanied stage plays reflected a similar division. The most popular melodrama of the period, Uncle Tom 's Cabin, provides a useful illustration. In Uncle Tom's Cabin on the American Stage and Screen, John Frick details a "typical... Tom show visit to an American town or village" (1). The parade's opening was signaled by two bands, "one white, the other "colored,"' despite the fact that the spectators milling about the street during the parade that often accompanied a performance were "of all ages, races, sexes, and classes," (1). The floats that followed these segregated bands were similarly separated along color lines: Tom and Chloe waved from a float depicting the eponymous cabin while Legree and Marks followed in a cart and on a mule, respectively (2). These preliminary parades, then, clearly marked off white and black spaces both for the entertainers (the white and black bands) and for the characters from the play (Tom and Chloe, Legree and Marks).

These parades took their cues from the melodramas of this period that dramatized slavery, such as George Aiken's Uncle Tom's Cabin (1852). Aiken's theatrical rendition of Harriet Beecher Stowe's novel, for example, contains relatively few scenes in which black characters and white characters share the stage. Far more prevalent are scenes either marked as black or white spaces. Thus Aiken's play opens with a scene in a "plain chamber" where Eliza and George lament their plight and this scene is followed by a "dining room" setting where Shelby and Haley converse over "dessert, wine, \&c" $(375,377)$. Act II reverses this pairing, with a scene in a "handsome parlor" preceding later scenes in the aforementioned "plain chamber," the latter being Aiken's stock setting for scenes dominated by actors portraying slaves (386, 399). Where Brown drew on his background with panoramas to inform his melodramatic 
juxtapositions discussed earlier, here these segregated spaces pass by in a way not unlike the Tom Show floats, placed side-by-side on the page but rarely overlapping on the stage. ${ }^{16}$ My point here is not so much to provide commentary on a specific play-though Uncle Tom 's Cabin certainly suffices - but rather to describe a feature of the standard theatrical stage and to point towards the ways that Brown's performances resisted this segregation of theatrical space.

Much of The Escape, in its printed form, conforms to the standards of segregated theatrical space, but re-imagining Brown's performance reminds us of the phenomenological curiosity of his play. Indeed this is evident in the very opening scene of the play where, at first glance, Brown's stage directions could have been lifted from any number of melodramas from the period: "MRS. GAINES, looking at some drawings - Sampey, a white slave, stands behind the lady's chair" (5). Were this scene to be staged traditionally, there might be little to comment on. However, when we keep in mind that Brown performed alone onstage, these directions mark a clear divergence between text and embodied performance. Even if Brown read these directions to his audience, the resulting tension isn't wholly alleviated. A black man, and former slave, thus embodies a white woman and a white slave, collapsing spatial and racial divides (a point further reinforced by Brown's description of Sampey as a "white slave," a phrase that inherently challenges the racial foundations of slavery in America). Brown's now infamous statement on the ways that slavery resists representation are here presented, through performance, in a more complex way: slavery cannot be represented in isolation. Instead, representing slavery requires that we cut across barriers of gender, class, and race, and Brown performed this process for those who attended his performances.

Yet stage melodramas were especially coy about representing sexual relations between master and slave, relations that produced "white slaves" such as Sampey. White slaves, mulattos, 
or quadroons were prevalent in the fiction and drama from the period, with the "tragic mulatto" used to, in the words of Joseph Roach, "condense... hatred and desire in the same imaginary liquid—mixed blood” (182). In Dion Boucicault's The Octoroon (1859), for instance, Zoe troubles simple binaries of white/black, as a woman desired for her outward whiteness and subjugated to slavery for her racial heritage. Though it is well known that Zoe "is the daughter of the judge," George, her lover, finds that "she is treated by the neighbors with a kind of familiar condescension" (454). She is, in short, a woman whose lineage is known but rarely commented on, her "mixed blood" a worrisome sign of the permeable boundaries between whites and blacks. Rather than explore these boundaries, at the end of the play she must die so that she can go "up dar, whar dere's no line atween folks," a vision of heaven that lacks a hope for an end to slavery in Zoe's lifetime (494).

Aiken's Uncle Tom's Cabin contains a character in Eliza who, like Zoe, adopts the role of the tragic mulatto. Also like Zoe, Eliza's lineage is hardly explored, and even her "whiteness" is alluded to without being explicitly expressed in any way other than the value such pale beauty holds in a slave economy. Thus Haley tells Shelby, "You might make your fortune on that ar gal in Orleans any day," for "I've seen over a thousand in my day, paid down for gals not a bit handsomer" (379). Later, in the midst of fleeing to Canada, Eliza encounters Phineas - a slaveowner-who doesn't recognize her as a fleeing slave. Nonetheless, upon first seeing Eliza, the man greets her by asking, "What's the matter? You look kind of streaked" (382). Here Phineas uses a word ("streaked") that both describes Eliza's agitated state and alludes to the "blackness" that hints at her mixed race for, not incidentally, "streaked" is far more common as an adjective used to describe the appearance of animals and plants than to describe an agitated state. ${ }^{17}$ Such a subtle marker does the double duty here as it reminds audiences of Eliza's tainted blood and 
moves the narrative forward as Phineas fails to understand both sides of his own double entendre.

The Escape as a dramatic publication offers its own representation of slave owners who deny slaves their basic human rights while endeavoring to hide their sexual encounters with their female slaves. When confronted about whether or not he fathered a child with his slave, Mr. Wildmarsh belies his own guilt by refusing to answer definitively: "You know, Mr. Walker, that people will talk, and when they talk, they say a great deal; and people did talk, and many said the gal was my daughter; and you know we can't help people's talking” (17). To ensure that audiences are aware of the widespread instances of master and slave relations, Brown features Dr. Gaines' guilt as well. When Major Moore comes to visit the doctor, the Major comments on Sampey to Mrs. Gaines: “Madam, I should have known that this was the Colonel's son, if I had met him in California; for he looks so much like his papa" (27). Though Moore apologizes for his error, Mrs. Gaines takes no offense, for "mistakes will be made," a response that highlights a practice so commonplace as to be beyond reproach (28). In short, there is nothing radical about Brown's treatment of miscegenation when looking at The Escape as a dramatic text. Miscegenation is treated as an opportunity for (admittedly biting) humor, as an aspect of slavery that is both prevalent and, for the whites in the play, unworthy of polite conversation.

Miscegenation on the melodramatic page (Brown's text included) thus reflects the inability (or unwillingness) of melodrama on the stage to represent the shared space of sexual intercourse between master and slave. This was true, on its most basic level, for practical reasons. Even as the theatre was becoming a more popular and more accepted site for entertainment, playwrights like Boucicault and Aiken were writing in an environment not all that far removed from a time only a few decades earlier when "a Puritan-based disdain for the 
ungodliness of the theater" permeated the Northeast (Nathans 26). ${ }^{18}$ Antebellum playwrights could create characters that were borne of miscegenation and make bawdy allusions to sex between master and slave, but the act in question remained, as Brown would write about slavery, un-representable. Playwrights nonetheless conveyed a familiar message to audience members by using humor to sidestep more serious racial dialogue. Frank Shuffleton writes that "ethnic humor is related to gender humor, whereby sexual social dominance is revealed and determined by who tells the jokes" (165). ${ }^{19}$ Thus a key difference results when comparing Aiken's Uncle Tom 's Cabin or Boucicault's The Octoroon with The Escape. Brown used a familiar technique-jokes about miscegenation — but the fact that Brown gets to play all parts inverts the traditional "social dominance" enacted when white actors play black roles onstage.

Comparing the traditional tragic mulatto figure of standard melodramas with Brown's one-man monodrama helps to further illustrate his performance of miscegenation. As we have seen, melodramas from the period contain subtle, often coded signals meant to remind audiences of a character's mixed race ("You look kind of streaked"). These signals were largely necessary because the same visual cues that purported to "mark" race (i.e. skin color) were problematized by the all-white casts who took the stage. In the cases of Uncle Tom's Cabin and The Octoroon, Eliza and Zoe would have been portrayed onstage by white actors who, presumably, were not wearing blackface. Put differently, there were no visual cues that distinguished between white characters played by white actors and mixed race characters played by white actors. ${ }^{20}$ The mulatto, as presented onstage, troubles the binary of race both ideologically and phenomenologically. Early Americans believed race was inherent and not a social construct, and so those of different races should be readily identifiable. The white actress who performs racial amalgamation links race to performance, which, in turn, undercuts claims about the biological 
inferiority of blacks.

The Escape as monodrama, though, allowed a man who was himself a product of intercourse between master and slave to perform miscegenation while remaining within the bounds of propriety. Standing at the front of courthouses and churches in the Northeast, Brown voiced white and black characters in a performance, at its core, of how far a white master would go to have sex with his slave. Indeed, a condensed summary of the play highlights this foundational trajectory of the dramatic plot: Dr. Gaines ventures to "roast [Glen] at the stake" to keep him away from Melinda, and the doctor imprisons Melinda on Poplar Farm to hide his intentions from Mrs. Gaines (30). By performing the roles of both master and slave, and by standing before audiences as the result of sex between master and slave, Brown collapses the distance between character(s) and actor.

We might revisit the review that opened this chapter with its competing descriptions of Brown's disappearance as a lecturer and presence during his performances, reflecting on the ways that Brown's decision to perform alone in courthouses and churches was strategic. First, Brown re-oriented audiences who were accustomed to discrete spaces deemed acceptable for entertainment (the theatre) and cultural critique (the lecture circuit) by performing outside the theatre and by presenting a melodrama as monodrama. Second, Brown counteracted the possibility that an audience might "lose sight of the speaker." No longer content to remain behind the shifting authorial persona who wrote (and re-wrote) Clotel, it is in The Escape that Brown couples men and women, masters and slaves, forcing viewers to confront the sexual violence inherent to slavery. Perhaps, then, we come to understand why The Escape has been so often overlooked by theatre historians, as Brown utilized the idea of the stage and the genre of melodrama but succeeded largely by never entering the playhouse. 
Notes

${ }^{1}$ See Henry Louis Gates Jr.'s Signifying Monkey: A Theory of African American Literary

\section{Criticism.}

${ }^{2}$ Levine draws upon the lesser-known definition of a "plagiary" as a person who abducts someone else's children or slaves. As Levine writes, "By that definition, the abolitionists who attempted to help the slaves escape from the slave catchers unleashed by the Fugitive Slave Law of $1850 \ldots$...could be understood metaphorically as types of plagiarists" (6).

${ }^{3}$ M. Giulia Fabi finds that Brown's revisions, particularly the latest version's “emphasis on the sentimental plot" results from changes in the interim between editions, most notably the abolition of slavery and the ratification of the fifteenth amendment, which gave black men the right to vote (NP).

${ }^{4}$ See https://archive.org/stream/southsideviewofs100adam\#page/n5/mode/2up for the digitized text in full.

${ }^{5}$ Taken one step further, I would argue that these solid structures also helped to signal the staying power of the U.S. as a nation.

${ }^{6}$ Brown's primary reason for traveling to Europe was to begin service as a delegate for the American Peace Society to the Peace Congress in Paris.

${ }^{7}$ In an 1860 letter published in The Liberator, “A.H." echoes this description, though in this case while describing a dramatic reading of Experience, which included descriptions of "the scourgings of the lash.” Despite such a serious topic, the author's concise summary of this moment is indicative: "This experience is given in a manner that creates hearty laughter." Where lecture left off and dramatic reading began was no doubt difficult to pin down, as Brown blurred 
the lines between autobiographical oral narratives and "dramas [which contain] passages of rare beauty" ("Letter 1).

${ }^{8}$ Farrison cites Mrs. Martha Coffin Wright's diary, in which she describes Brown's visit to Auburn, New York where he lectured on Sunday, April 26 and read Experience on Monday, April 27, and The Escape on Tuesday, April 28 (284-5). Thus it is likely that, at least early on, these dramatic performances accompanied his lectures to some degree.

${ }^{9}$ Harry J. Elam finds that Brown wrote The Escape "in lieu of an oratorical address, at northern abolitionist meetings" (291).

${ }^{10}$ William Brown's theatre underwent a series of name changes, from African Grove to Minor Theatre to American Theatre to African Company (McAllister 6).

${ }^{11}$ See also, Errol G. Hill's "The African Theatre to Uncle Tom's Cabin."

${ }^{12}$ It is possible that in calling this "Poplar Farm" Brown links The Escape to Clotel as a reference to Poplar Forest, which was Jefferson's second plantation and retreat.

${ }^{13}$ As Jeffrey Richards reminds us, early American dramatic publications often were circulated concurrently with their playhouse performances, as "the circulation of printed scripts — or hand copies of same — made audiences very knowing of what they would see and critical when actors missed lines or prompters and managers deleted passages that they expected or demanded" ("Print" 75-6).

${ }^{14}$ See my discussion of the panorama in relation to Barnes' The Forrest Princess in chapter 3, "Placing 'History' Onstage: Re-fashioning the Pocahontas Narrative in Barker's The Indian Princess and Barnes' The Forest Princess."

${ }^{15}$ Costola draws the comparison between Brown's Panoramas and Walter Benjamin's 
“dialectical images," arguing that Brown “displaced his audience members' expectations by showing what constituted a possible obscene-i.e., what could lie outside the box of representation" (25-8).

${ }^{16}$ One notable exception, of course, were the slave auction scenes that brought slaves and whites together in one setting.

${ }^{17}$ See the Oxford English Dictionary's entry for "streaked."

${ }^{18}$ Heather Nathans locates this trend in the late 1700s, and she links these puritanical objections with the political objections to theatre that followed from denouncements of the theatre as, like the abhorred Stamp Act, a tax on the people (26).

${ }^{19}$ Though race and ethnicity aren't interchangeable terms, Shuffleton's text is interested in both as evidenced by its title, Mixed Race: Ethnicity in Early America.

${ }^{20}$ Auditory cues also tended to be absent when it came to mulatto characters. Uncle Tom's Cabin's Eliza, for instance, speaks without the "black” dialect spoken by Topsy. Similarly, The Octoroons's Zoe speaks in a dialect indistinguishable from George, while Paul, a black slave, speaks in a dialect similar to Topsy. 


\section{Epilogue: All Theatre is Environmental, All Performance is Site-Specific}

The turn of the twenty-first century brought with it a renewed critical and popular interest in site-specific performances. Though these performances took place in diverse settings, in different countries, and with different agendas, they all shared a common belief that specific sites shape the performances that occur in these spaces, and that these performances transform these spaces of articulation. Just as important, production companies found in site-specific performances a mode of theatrical inquiry that could be adopted as fruitfully for avant-garde performances as for Shakespearean adaptations.

For instance, in 2002 the Knowhere theatre company held performances in Saskatchewan's Weyburn Mental Hospital to interrogate "the rise and decline in the need for institutional care of the mentally ill." The Weyburn Project, as it was called, used "nonfunctioning areas of the hospital," as "the building itself draws focus and provides an archeological or forensic site of investigation for actors and spectators alike" (Weyburn). In this same year, a Singaporean troupe performed Search: Hamlet in a Denmark castle. Search: Hamlet encouraged spectators to "choose one of the simultaneous guided tours through the basement or different rooms of the castle, walking past costumes and other actors in preparation," before spectators moved on to the castle's courtyard. As one might expect based on the title, Hamlet was sought within the castle, but never seen (Huang 77). Alexander C.Y. Huange writes that this site-specific performance was "defined by its local specificities that will be lost on a different audience in a different performance venue or context" (74). Put differently, this site-specific performance utilized the phenomenological experience of theatre to generate meaning for spectators and players alike. 
Such performances find their roots in Richard Schechner's Environmental Theater, first published in 1973. Schechner's decision to describe the theatre as environmental is crucial to his larger project. "Neither ecological nor performance environments are passive," he writes, as "they are interactants in events organically taking place throughout vivified spaces" (x). Thus in the cases of the Weyburn Project's performance in a mental hospital and the performance of Search: Hamlet in a Denmark castle, these sites aren't performed on by players, but rather the sites are organic contributors to the respective performances. Nor is this phenomenon restricted to the immediate space of the performance. Schechner notes that "even the toilets and the transportation systems conveying people to and from the theater are part of the "performance environment"' (x). With this comment Schechner seems to open the door for an exploration of the ways that sites matter to performance, even those spatial elements that aren't carefully choreographed by producers and directors.

Yet in his manifesto, Schechner is careful to define environmental theatre in opposition to the "orthodox theatre" of the playhouse. In fact, he seems to take great pleasure in the idea that "the orthodox theater is shrinking," as he argues that "the indoor theater in which every play is fitted into the same space modified on its surface by means of scene design and lighting is the minor tradition," while "environmental theater is the major tradition" (xv). Schechner ultimately concludes that even though "academicians" haven't "got the message" yet, the environmental theatre "is the American theater" (xv).

I contend that this is indeed the case, that American theatre is environmental theatre, and always has been, though not necessarily in the way that Schechner would have us believe. While "academicians" have finally received the message, they, like Schechner, have limited themselves to analyzing self-consciously site-specific performances. As one such scholar writes, "While it 
may be premature to declare the death of the theatre text, it is certainly clear that site-specific performance has allowed us to think of the 'performance text' in much more complex ways, uniting written, verbal and non-verbal signs, critical and cultural reception, intertexts, cultural noise and so on" (McEvoy 591). An unnecessary divide is thus forged between critics interested in the "orthodox" theatre (taken here to be a site of less complex engagement, a place that is dying, if not yet dead) and critics who study performances that are environmental by design.

Each of the preceding chapters offers evidence to the contrary, showing us that all performances - from the textual performance of closet drama to "orthodox" playhouse performances, to performances in alternative venues—are site-specific, even if less selfconsciously so than the avant-garde productions that Schechner favors. It is only when we pay close attention to what "orthodox" theatrical space symbolized for early Americans - a reflection of the nation and its citizens - that we can truly locate the ways that early American playwrights responded to, and in some cases resisted, the meanings attached to theatrical space.

Mercy Otis Warren's closet drama thus becomes far more than an historical document of Revolutionary America when we examine its relation to the burgeoning public sphere, the displaced theatre of Boston, and the domestic spaces long associated with closeted texts. Charlotte Barnes' discomfort with the ways that nation-building discourse was being transliterated into theatrical staging signals her anxiety over who gets elided when theatrical space must reflect the embodiment of a nation's citizens. In George Aiken's Uncle Tom's Cabin and Dion Boucicault's The Octoroon the theatre is re-affirmed as a site that reflected the nation and its citizens, but only by portraying slaves onstage as foreign. Finally, William Wells Brown's The Escape has been mostly ignored for more than 150 years because the text left behind doesn't easily convey the complexities inherent to his mono-dramatic performances, but 
these complexities can be recovered by understanding Brown's lecture performances as a calculated reaction to the restrictions of the antebellum stage. We see in this collection, then, that if early American performances seem orthodox, the fault lies in our own limited abilities to reimagine the sites where performance takes place, whether that be on the stage, in the home, or within churches and courthouses.

There is much to be gained from taking this theoretical stance. As I have argued throughout this project, investigating the spatial orientations of early American drama in its various forms sheds light on the placelessness and displacement that defined the early republic and its people. Perhaps less apparent but no less important are the ways that a site-specific investigation stands to expand our understanding of how space intersects with early American identity. In her study of modern realist drama, Una Chaudhuri writes that "national and ethnic identities are often derived from or directed towards a geography, there is a location of identity based on race, nation, ethnicity, language - in short, all the elements that together or in part designate the notion of a culture" (3). By extension, early Americans experienced the dislocation of identity based on race and nation, as in Pocahontas plays that locate American origins in a people who, ironically, must be erased at the same moment they are claimed, or when white audiences found themselves placed in the stead of foreign slaves in plays by Aiken and Boucicault.

Noticeably absent from this discussion of American identity is gender. In fact, Chaudhuri points out that gender often stands apart from race, nation, ethnicity, and language, implying that there is no geography of gender (3). Yet Mercy Otis Warren's closet drama, with its insistence on a gendered public sphere, opens up the possibility for theorizing the intersections of space and gender. If The Group stands out as an exception, as a text interested in the geographies of gender, 
it shows us by contrast the gender-norming inherent to most canonical plays from the period, a period dominated by white, male playwrights. Nonetheless, drama-with its clear spatial orientations — seems well positioned as a way into this necessary discussion, which might yield far richer interpretations of early performance in America.

Indeed, space shapes dramatic genres in ways that we haven't fully realized. This dissertation, for instance, re-evaluates several melodramas that may seem unremarkable at first glance, as plays that conform to the rigid constraints of the melodramatic genre. Yet a closer look at The Forest Princess, Uncle Tom's Cabin, The Octoroon, and The Escape reveals the elasticity of a genre that has long been denigrated as a theatre for the masses, without subtlety or nuance. While much of the critical work on melodrama is interested in defining this genre, pinning down how it works and why it was so popular in early America, a site-specific analysis of the aforementioned performances helps us to understand how melodrama was used by playwrights, to uncover what it helped them to achieve, and, as was the case in Barnes' play, to reveal how this genre could also resist a writer's goals.

In his introduction to a collection of early American dramas (one of the few such volumes that remains in print), Jeffrey Richards makes a bold claim for the ways that these texts contribute to our understanding of American literary history. "To understand the rest of American literature, one has to understand its drama and theater," he writes, for "of all entertainments, theater was perhaps the closest to a universal experience for most Americans" (Introduction xix). To this I would add that to understand drama and theatre- and by extension, American literary history — more fully, we must see all theatre as environmental, we must understand all performance as site-specific. In short, we must work harder to re-imagine these 
places of performance, for it is only in doing so that we might uncover the past that shapes our present. 


\section{Works Cited}

“Actors and Actresses: Recollections of a Theatre Goer.” New York Times Jul. 4, 1875. 4.

Adams, Nehemiah. A South-Side View of Slavery. $4^{\text {th }}$ Ed. Boston: Ticknor and Fields, 1860.

Agamben, Giorgio. State of Exception. Chicago: U of Chicago P, 2005.

Aiken, George L. Uncle Tom's Cabin; or, Life Among the Lowly. Early American Drama. Ed. Jeffrey H. Richards. New York: Penguin, 1997. 373-443.

“American Slavery.” Liberator. 9 Aug. 1850. 126.

“Amusements.” New York Times. 2 Mar. 1865. 7.

Anderson, Kurt. “1848: When America Came of Age.” Time. 8 March 2007. Web. 16 Feb. 2013.

Andrews, William L. "The Novelization of Voice in Early African American Narrative." PMLA 105.1 (1990): 23-34.

Bak, John S. “James Nelson Barker's The Indian Princess: The Role of the Operatic Melodrama in the Establishment of an American Belles-lettres." Studies in Musical Theatre 2.2 (2008): 175-93.

Baker, Jennifer J. Securing the Commonwealth: Debt, Speculation, \& Writing in the Making of Early America. Baltimore: The Johns Hopkins UP, 2005.

Baldwin, James. "Everybody's Protest Novel.” Uncle Tom's Cabin. Ed. Elizabeth Ammons. New York: Norton, 1994.

Bank, Rosemarie. Theatre Culture in America, 1825-1860. New York: Cambridge UP, 1997. Bannet, Eve Tavor. Transatlantic Stories and the History of Reading, 1720-1810: Migrant Fictions. New York: Cambridge UP, 2011.

Baraw, Charles. "William Wells Brown, Three Years in Europe, and Fugitive Tourism.” African American Review 44.3 (2011): 453-70. 
Barker, James Nelson. The Indian Princess. Early American Drama. Ed. Jeffrey H. Richards. New York: Penguin, 1997. 114-65.

Barnes, Charlotte Mary Sanford. The Forest Princess. Plays by Early American Women, 17751850. Ed. Amelia Howe Kritzer. Ann Arbor: U of Michigan P, 1995. 321-68.

Baym, Nina. American Women Writers and the Work of History, 1790-1860. New Brunswick, NJ: Rutgers UP, 1995.

Bhabha, Homi K. "DisseMination: Time, Narrative, and the Margins of the Modern Nation." Nation and Narration. Ed. Homi K. Bhabha. New York: Routledge, 1990. 291-322.

Bird, Robert Montgomery. The Gladiator. Early American Drama. Ed. Jeffrey H. Richards. New York: Penguin, 1997. 171-242.

Blight, David W. Race and Reunion: The Civil War in American Memory. Cambridge, MA: Harvard UP, 2001.

Botelho, Keith M. “'Look on this picture, and on this': Framing Shakespeare in William Wells Brown's The Escape.” Comparative Drama 39.2 (2005): 187-212.

Boucicault, Dion. The Octoroon. Early American Drama. Ed. Jeffrey H. Richards. New York: Penguin, 1997. 449-94.

Bowen, Daniel. A History of Philadelphia. Philadelphia: Printed and Published by Daniel Bowen, 1839.

Brickhouse, Anna. “Mistranslation, Unsettlement, La Navidad.” PMLA 128.4 (2013): 938-46.

Brockett, Oscar G and Franklin J. Hildy. History of the Theatre. 10 ${ }^{\text {th }}$ ed. Boston: Pearson, 2008.

Brooks, Peter. The Melodramatic Imagination: Balzac, Henry James, Melodrama, and the Mode of Excess. New Haven: Yale UP, 1976.

Brown, Jared. The Theatre in America During the Revolution. New York: Cambridge UP, 2007. 
Brown, William Wells. Clotel; or, The President's Daughter: A Narrative of Slave Life in the United States. Ed. Robert S. Levine. Boston: Bedford/St. Martin's, 2000.

---. The Escape, Or, A Leap for Freedom: A Drama in Five Acts. Ed. John Ernest. Knoxville: U of Tennessee P, 2001.

Brueckner, Martin. The Geographic Revolution in Early America: Maps, Literacy, \& National Identity. Chapel Hill: U of North Carolina P, 2006.

Bryan, George B. American Theatrical Regulation, 1607-1900: Conspectus and Texts. Metuchen, NJ: Scarecrow Press, 1993.

Buell, Lawrence. The Future of Environmental Criticism: Environmental Crisis and Literary Imagination. Malden, MA: Blackwell, 2005.

---. Writing for an Endangered World: Literature, Culture, and Environment in the U.S. and Beyond. Cambridge, MA: Harvard UP, 2001.

Burroughs, Catherine. "The Persistence of Closet Drama: Theory, History, Form.” The Performing Century: Nineteenth-Century Theatre History. Eds. Tracy C. Davis and Peter Holland. New York: Palgrave Macmillan, 2007. 215-35.

Carlson, Marvin. The Haunted Stage: The Theatre as a Memory Machine. Ann Arbor: U of Michigan P, 2001.

---. Places of Performance: The Semiotics of Theatre Architecture. Ithaca: Cornell UP, 1989.

---. Theories of the Theatre: A Historical and Critical Survey, from the Greeks to the Present. Ithaca: Cornell UP, 1984.

Carr, Mary. The Fair Americans: A Play of the War of 1812. Plays by Early American Women, 1775-1850. Ed. Amelia Howe Kritzer. Ann Arbor: U of Michigan P, 1995. 183-215. Carter, Erica, James Donald, and Judith Squires. Introduction. Space and Place: Theories of 
Identity and Location. Eds. Erica Carter, James Donald, and Judith Squires. London: Lawrence \& Wishart, 1993. 3-32.

Certeau, Michel de. The Practice of Everyday Life. Berkeley: U of California P, 1988.

Chapman, Mary. “'Living Pictures': Women and Tableaux Vivants in Nineteenth-Century American Fiction and Culture." Wide Angle 18.3 (1996): 22-52.

Chaudhuri, Una. Staging Place: The Geography of Modern Drama. Ann Arbor: U of Michigan $\mathrm{P}, 1995$.

Chernow, Ron. Alexander Hamilton. New York: Penguin, 2004.

Chiles, Katy L. "Blackened Irish and Brownfaced Amerindians: Constructions of American Whiteness in Dion Boucicault's The Octoroon." Nineteenth Century Theatre \& Film 31.2 (2004): 28-50.

Cima, Gay Gibson. "Black and Unmarked: Phillis Wheatley, Mercy Otis Warren, and the Limits of Strategic Anonymity.” Theatre Journal 52 (2000): 465-95.

Costola, Sergio. "William Wells Brown's Panoramic Views." Journal of American Drama and Theatre 24.2 (2012): 13-31.

Craven, Wesley Frank. “A New Edition of the Works of John Smith.” The William and Mary Quarterly 29.3 (1972): 479-86.

Dillon, Elizabeth Maddock. "Slaves in Algiers: Race, Republican Genealogies, and the Global Stage." American Literary History 16.3 (2004): 407-36.

Dunlap, William. A History of the American Theatre from Its Origins to 1832. Chicago: U of Illinois P, 2005.

Elam, Harry J. "The Black Performer and the Performance of Blackness: The Escape; or, A Leap to Freedom by William Wells Brown and No Place to Be Somebody by Charles 
Gordone." African American Performance and Theater History: A Critical Reader. Eds. Harry J. Elam, Jr. and David Krasner. New York: Oxford UP, 2001. 288-305.

Elliot, J.H. Empires of the Atlantic World: Britain and Spain in America, 1492-1830. New Haven, Yale UP, 2006.

Engell, John. "Narrative Irony and National Character in Royall Tyler's The Algerine Captive." Studies in American Fiction 17.1 (1989): 19-32.

Ernest, John. Introduction. The Escape, Or, A Leap for Freedom: A Drama in Five Acts. Ed. John Ernest. Knoxville: U of Tennessee P, 2001. ix-li.

---. Liberation Historiography: African American Writers and the Challenge of History, 17941861. Chapel Hill: U of North Carolina P, 2004.

---. “The Reconstruction of Whiteness: William Wells Brown's The Escape; or, A Leap for Freedom." PMLA 113.5 (1998): 1108-21.

---. "William Wells Brown Maps the South in My Southern Home: Or, the South and Its People." Southern Quarterly: A Journal of the Arts in the South 45.3 (2008): 88-107.

Fabi, M. Giulia. “The 'Unguarded Expressions of the Feelings of the Negroes': Gender, Slave Resistance, and William Wells Brown's Revisions of Clotel." African American Review 27.4 (1993): 639-54.

Farrison, William Edward. William Wells Brown: Author and Reformer. Chicago: U of Chicago P, 1969.

Fliegelman, Jay. Declaring Independence: Jefferson, Natural Language, \& the Culture of Performance. Stanford: Stanford UP, 1993.

Fraser, Nancy. "Rethinking the Public Sphere: A Contribution to the Critique of Actually Existing Democracy.” Social Text 25/26 (1990): 56-80. 
Frick, John W. Uncle Tom's Cabin on the American Stage and Screen. New York: Palgrave Macmillan, 2012.

Gallagher, Edward J. The Pocahontas Archive. Lehigh University, Oct. 2009. Web. 23 August 2013.

Garner, Stanton B. Bodied Spaces: Phenomenology and Performance in Contemporary Drama. Ithaca: Cornell UP, 1994.

Gates, Henry Louis, Jr. Signifying Monkey: A Theory of African-American Literary Criticism. New York: Oxford UP, 1988.

Gould, Philip. Writing the Rebellion: Loyalists and the Literature of Politics in British America. New York: Oxford UP, 2013.

Green, Rayna. "The Pocahontas Perplex: The Image of Indian Women in American Culture.” The Massachusetts Review 16.4 (1975): 698-714.

Green-Barteet, Miranda A. “"The Loophole of Retreat': Interstitial Spaces in Harriet Jacobs's Incidents in the Life of a Slave Girl." South Central Review 30.2 (2013): 53-72.

Grimsted, David. "Uncle Tom From Page to Stage: Limitations of Nineteenth-Century Drama." The Quarterly Journal of Speech 56.5 (1970): 235-44.

Gustafson, Sandra M. Eloquence is Power: Oratory \& Performance in Early America. Chapel Hill: U of North Carolina P, 2000.

Gustafson, Sandra M. and Caroline F. Sloat, eds. Cultural Narratives: Texuality and Performance in American Culture before 1900. Notre Dame: U of Notre Dame P, 2010. Habermas, Jurgen. The Structural Transformation of the Public Sphere: An Inquiry into a Category of Bourgeois Society. Trans. Thomas Burger. Boston: MIT Press, 1991. Hancock, David. "Self-Organized Complexity and the Emergence of an Atlantic Market 
Economy, 1651-1815: The Case of Madeira." The Atlantic Economy During the Seventeenth and Eighteenth Centuries: Organization, Operation, Practice, and Personnel. Ed. Peter A. Coclanis. Columbia: U of South Carolina P, 2005. 30-71. Hartman, Saidiya. Scenes of Subjection: Terror, Slavery, and Self-Making in Nineteenth-Century America. New York: Oxford UP, 1997.

Hibberd, Sarah and Nanette Nielson. "Music in Melodrama: 'the Burden of Ineffable Expression'?" Nineteenth Century Theatre and Film 29.2 (2002): 30-39.

Hill, Errol G. "The African Theatre to Uncle Tom's Cabin." A History of African American Theatre. Eds. Errol G. Hill and James V. Hatch. New York: Cambridge UP, 2003. 24-60. Hodge, Francis. Yankee Theatre: The Image of America on the Stage, 1825-1850. Austin: U of Texas P, 2014.

Holt, Keri. “'All Parts of the Union I Considered My Home': The Federal Imagination of The Algerine Captive." Early American Literature 46.3 (2011): 481-515.

Hornblow, Arthur. A History of the Theatre in America from Its Beginnings to the Present Time. Philadelphia: J.B. Lippincott, 1919.

Houchin, John H. "Culture War: Professional Theatre and Popular Sovereignty in EighteenthCentury Boston." The New England Theatre Journal 10 (1999): 27-45.

Huange, Alexander C.Y. "Siting and Citing Hamlet in Elsinore, Denmark." The Hamlet Zone: Reworking Hamlet for European Cultures. Ed. Ruth J. Owen. New York: Cambridge Scholars, 2013. 73-84.

Huhndorf, Shari. Going Native: Indians in the American Cultural Imagination. Ithaca: Cornell UP, 2001.

Hutcheson, Maud Macdonald. "Mercy Warren, 1728-1814." William and Mary Quarterly 10 
(1953): 378-402.

Hutchison, Coleman. Apples and Ashes: Literature, Nationalism, and the Confederate States of America. Athens: U of Georgia P, 2012.

The Influence and History of the Boston Athenaeum: From 1807 to 1907. Boston: Robert Charles Billings Fund, 1907.

Jacobson, Matthew Frye. Whiteness of a Different Color: European Immigrants and the Alchemy of Race. Cambridge, MA: Harvard UP, 1998.

Jaroff, Rebecca. “Opposing Forces: (Re)Playing Pocahontas and the Politics of Indian Removal on the Antebellum Stage." Comparative Drama 40.4 (2007): 483-504.

Johnson, Odai. Absence and Memory in Colonial American Theatre: Fiorelli's Plaster. New York: Palgrave MacMillan, 2006.

---. "Drama in the Academies of Early America." Early Modern Academic Drama. Eds. Jonathan Walker and Paul D. Streufert. Burlington, VT: Ashgate, 2008. 175-88.

Kelley, Mary. “'The Need of Their Genius”: Women's Reading and Writing Practices in Early America." Journal of the Early Republic 28 (2008): 1-22.

Kippola, Karl M. Acts of Manhood: The Performance of Masculinity on the American Stage, 1828-1865. NewYork: Palgrave Macmillan, 2012.

Kokai, Jenny. “'Humble Adventures in the Career of Fame:' Female Intellectuals in Search of Public Embodied Voices.” Diss. U of Texas, 2008.

Kooy, Dana Van and Jeffrey N. Cox. "Melodramatic Slaves.” Modern Drama 55.4 (2012): 45975.

Kritzer, Amelia Howe. Introduction. Plays by Early American Women, 1775-1850. Ed. Amelia Howe Kritzer. Ann Arbor: U of Michigan P, 1995. 1-28. 
---. "Playing With Republican Motherhood: Self-Representation in Plays by

Susanna Haswell Rowson and Judith Sargent Murray.” Early American Literature 31 (1996): 150-66.

Lancaster, A.E. "Historical American Plays." The Chautauquan; A Weekly Newsmagazine 31.4 (1900): 359 .

Larkin, Edward. "Nation and Empire in the Early U.S..” American Literary History 22.3 (2010): $501-26$.

“Letter From West Randolph.” Liberator. 31 Aug. 1860. 1.

Levine, Lawrence. Highbrow/Lowbrow: The Emergence of Cultural Hierarchy in America. Cambridge, MA: Harvard UP, 1988.

Levine, Robert S. Introduction. Clotel; or, The President's Daughter: A Narrative of Slave Life in the United States. Ed. Robert S. Levine. Boston: Bedford/St. Martin's, 2000. 3-27. Lindenberger, Herbert. Historical Drama: The Relation of Literature and Reality. Chicago: $\mathrm{U}$ of Chicago P, 1975.

Loeffelholz, Mary. "Miranda in the New World: The Tempest and Charlotte Barnes' The Forest Princess." Women's Re-Visions of Shakespeare: On the Responses of Dickinson, Woolf, Rich, H.D., George Eliot, and Others. Ed. Marianne Novy. Chicago: U of Illinois P, 1990. 58-75.

Looby, Christopher. Voicing America: Language, Literary Form, and the Origins of the United States. Chicago: U of Chicago P, 1996.

Lott, Eric. "Blackface and Blackness: The Minstrel Show in American Culture." Inside the Minstrel Mask: Readings in Nineteenth-Century Blackface Minstrelsy. Eds. Annemarie Bean, James V. Hatch, and Brooks McNamara. Hanover: Wesleyan UP, 1996. 3-32. 
---. Love and Theft: Blackface Minstrelsy and the American Working Class. New York: Oxford UP, 1993.

Loughran, Trish. The Republic in Print: Print Culture in the Age of U.S. Nation Building, 17701870. New York: Columbia UP, 2007.

Lucasi, Stephen. "William Wells Brown's Narrative \& Traveling Subjectivity.” African American Review 41.3 (2007): 521-39.

Margulis, Jennifer. "Spies, Pirates, and White Slaves: Encounters With the Algerines in Three Early American Novels." The Eighteenth-Century Novel 1 (2001): 1-36.

Maslan, Susan. "Resisting Representation: Theater and Democracy in Revolutionary France." Representations 52.1 (1995): 27-51.

Mason, Jeffrey D. Melodrama and the Myth of America. Bloomington: Indiana UP, 1993.

McAllister, Marvin. White People Do Not Know How to Behave at Entertainments Designed for Ladies \& Gentlemen of Colour: William Brown's African \& American Theater. Chapel Hill: U of North Carolina P, 2003.

McConachie, Bruce. Melodramatic Formations: American Theatre and Society, 1820-1870. Iowa City: U of Iowa P, 1992.

---. “Out of the Kitchen and into the Marketplace: Normalizing Uncle Tom's Cabin for the Antebellum Stage.” The Journal of American Drama and Theatre 3.1 (1991): 5-28.

McKittrick, Katherine. Demonic Grounds: Black Women and the Cartographies of Struggle. Minneapolis: U of Minnesota P, 2006.

---. "Freedom is a Secret: The Future Usability of the Underground." Black Geographies and the Politics of Place. Eds. Katherine McKittrick and Clyde Woods. Cambridge, MA: South End Press, 2007. 
McKittrick, Katherine and Clyde Woods. "No One Knows the Mysteries at the Bottom of the Sea." Black Geographies and the Politics of Space. Eds. Katherine McKittrick and Clyde Woods. Cambridge, MA: South End Press, 2007.

McEvoy, William. "Writing, Texts and Site-Specific Performance in the Recent Work of Deborah Warner.” Textual Practice 20.4 (2006): 591-614.

Meer, Sarah. Uncle Tom Mania: Slavery, Minstrelsy, and Transatlantic Culture in the 1850s. Athens: U of Georgia P, 2005.

Meserve, Walter J. Heralds of Promise: The Drama of the American People During the Age of Jackson, 1829-1849. New York: Greenwood Press, 1986.

Moldenhauer, Joseph J. "Thoreau, Hawthorne, and the 'Seven-Mile Panorama."” ESQ 44.4 (1998): 227-73.

Moore, Jack B. Introduction. The Algerine Captive; or, The Life and Adventures of Doctor Updike Underhill. By Royall Tyler. Gainesville: Scholars’ Facsimiles \& Reprints, 1967. v-xviii.

Mowatt, Anna Cora. Fashion; or Life in New York. Early American Drama. Ed. Jeffrey H. Richards. New York: Penguin, 1997. 310-67.

Murray, Judith Sargent. The Gleaner. Schenectady, NY: Union College P, 1992.

Nash, Gary B. First City: Philadelphia and the Forging of Historical Memory. Philadelphia: U of Pennsylvania P, 2002.

Nash, R.C. "The Organization of Trade and Finance in the British Atlantic Economy, 16001830." The Atlantic Economy During the Seventeenth and Eighteenth Centuries: Organization, Operation, Practice, and Personnel. Ed. Peter A. Coclanis. Columbia: U of South Carolina P, 2005. 95-151. 
Nathans, Heather. Early American Theatre from the Revolution to Thomas Jefferson: Into the Hands of the People. New York: Cambridge UP, 2003.

Nelson, Dana D. National Manhood: Capitalist Citizenship and the Imagined Fraternity of White Men. Durham: Duke UP, 1998.

North, Marcy L. The Anonymous Renaissance: Cultures of Discretion in Tudor-Stuart England. Chicago: U of Chicago P, 2003.

Nuss, Melynda. Distance, Theatre, and the Public Voice, 1750-1850. New York: Palgrave Macmillan, 2012.

Pangborn, Matthew. "Royall Tyler's The Algerine Captive, America, and the Blind Man of Philosophy." Arizona Quarterly 67.3 (2011): 1-27.

Peters, Julie Stone. Theatre of the Book 1480-1880: Print, Text, and Performance in Europe. New York: Oxford UP, 2003.

Pisani, Michael V. Imagining Native American Music. New Haven: Yale UP, 2005.

Poovey, Mary. Genres of the Credit Economy: Mediating Value in Eighteenth- and NineteenthCentury Britain. Chicago: U of Chicago P, 2008.

Quinn, Arthur Hobson. A History of the American Drama: From the Beginning to the Civil War. New York: F.S. Crofts \& Co., 1946.

Railton, Stephen. Uncle Tom's Cabin \& American Culture. utc.iath.virginia.edu.

Rasmussen, William M.S. and Robert S. Tilton. Pocahontas: Her Life \& Legend. Richmond: Virginia Historical Society, 1994.

Ready, Kathryn. "From the Stage to the Closet: Hannah More's Abandonment of Theater." Eighteenth-Century Women: Studies in Their Lives, Work, and Culture 4 (2006): 185214. 
Rebhorn, Matthew. 'Edwin Forrest's Redding Up: Elocution, Theater, and the Performance of the Frontier." Comparative Drama 40.4 (2006/7): 455-81.

---. "What is it? The Frontier, Melodrama, and Boucicault's Amalgamated Drama." Journal of American Drama and Theatre 19.3 (2007): 5-33.

Reed, Peter P. Rogue Performances: Staging the Underclasses in Early American Theatre Culture. New York: Palgrave MacMillan, 2009.

Reid, Mayne. The Quadroon; or, A Lover's Adventures in Louisiana. New York: R.M. De Witt, 1856.

“Retrospective Notice of American Literature: Article 5." Boston Review 5.8 (1808): 455-60.

Richards, Jeffrey H. “The Contrast (1787).” Early American Drama. Ed. Jeffrey H. Richards. New York: Penguin, 1997. 1-5.

---. Drama, Theatre, and Identity in the American New Republic. New York: Cambridge, UP, 2005.

---. Introduction. Early American Drama. New York: Penguin, 1997. ix-xlii.

---. Mercy Otis Warren. New York: Twayne Publishers, 1995.

---. “The Octoroon.” Early American Drama. Ed. Jeffrey H. Richards. New York: Penguin, 1997. 444-47.

---. "Politics, Playhouse, and Repertoire in Philadelphia, 1808." Theatre Survey 46.2 (2005): 199-224.

---. "Print, Manuscript, and Staged Performance: Dramatic Authorship and Text Circulation in the New Republic." Cultural Narratives: Textuality and Performance in American Culture before 1900. Eds. Sandra M. Gustafson and Caroline F. Sloat. Notre Dame: U of Notre Dame P, 2010. 73-96. 
---. Theater Enough: American Culture and the Metaphor of the World Stage. Durham: Duke UP, 1991.

---. “Uncle Tom's Cabin.” Early American Drama. Ed. Jeffrey H. Richards. New York: Penguin, 1997. 368-72.

Richards, Jeffrey H. and Sharon M. Harris. Mercy Otis Warren: Selected Letters. Athens: U of Georgia P, 2009.

Roach, Joseph. Cities of the Dead: Circum-Atlantic Performance. New York: Columbia UP, 1996.

Rowe, John Carlos. 'Highway Robberty: 'Indian Removal,' The Mexican-American War, and American Identity in The Life and Adventures of Joaquin Murieta." Novel: A Forum on Fiction 31.2 (1998): 149-73.

Rowson, Susanna Haswell. Slaves in Algiers. Plays by Early American Women, 1775-1850. Ed. Amelia Howe Kritzer. Ann Arbor: U of Michigan P, 1995. 55-95.

Samuels, Shirley. Introduction. The Culture of Sentiment: Race, Gender, and Sentimentality in Nineteenth-Century America. New York: Oxford UP, 1992. 3-8.

Sarkela, Sandra J. “Freedom's Call: The Persuasive Power of Mercy Otis Warren's Dramatic Sketches, 1772-1775." Early American Literature 44.3 (2009): 541-68.

Schechner, Richard. Environmental Theater. New York: Applause, 1994.

Scheckel, Susan. The Insistence of the Indian: Race and Nationalism in Nineteenth-Century American Culture. Princeton: Princeton UP, 1998.

Schell, Jennifer. "Figurative Surveying: National Space and the Nantucket Chapters of J. Hector St. John de Crevecoeur's Letters from an American Farmer." Early American Literature 43.3 (2008): 581-604. 
---. “This Life is a Stage': Performing the South in William Wells Brown's Clotel or, The President's Daughter." Southern Quarterly: A Journal of the Arts in the South 45.3 (2008): 48-69.

Schopp, Joseph. “Liberty's Sons and Daughters: Susanna Haswell Rowson's and Royall Tyler's Algerine Captives." Early America Re-Explored: New Readings in Colonial, Early National, and Antebellum Culture. New York: NY: Peter Lang, 2000. 291-307.

Shafer, Jason. Performing Patriotism: National Identity in the Colonial and Revolutionary American Theater. Philadelphia: U of Pennsylvania P, 2007.

Shields, David S. Civil Tongues \& Polite Letters. Chapel Hill: U of North Carolina P, 1997. Shuffleton, Frank. Mixed Race: Ethnicity in Early America. New York: Oxford UP, 1993. Shweiger, Beth Barton. "A Social History of English Grammar in the Early United States." Journal of the Early Republic 30 (2010): 533-55.

Sinche, Bryan. "William Wells Brown's Economy of Entertainment." African American Review 45.1-2 (2012): 83-98.

Smith, John. The Generall Historie of Virginia, New England \& The Summer Isles Together with The True Travels, Adventures and Observations, and a Sea Grammar: Volume I. Glasgow: James MacLehose and Sons, 1907.

Smith, William Henry. The Drunkard. Early American Drama. Ed. Jeffrey H. Richards. New York: Penguin, 1997. 248-303.

States, Bert O. Great Reckonings in Little Rooms: On the Phenomenology of Theater. Berkeley: U of California P, 1985.

Stowe, Harriet Beecher. Uncle Tom 's Cabin. Ed. Elizabeth Ammons. New York: Norton, 1994. Straub, Julia. "Early American Literature: Canon Theory in a Transatlantic Context." 
Comparative American Studies 9.2 (2011): 106-18.

Straznicky, Marta. Privacy, Playreading, and Women's Closet Drama, 1550-1700. New York: Cambridge UP, 2009.

Stupp, Jason. "Slavery and the Theatre of History: Ritual Performance on the Auction Block." Theatre Journal 63.1 (2011): 61-84.

Tamarkin, Elisa. Anglophilia: Deference, Devotion, and Antebellum America. Chicago: U of Chicago P, 2007.

Tilton, Robert S. Pocahontas: The Evolution of an American Narrative. New York: Cambridge UP, 1994.

Turner, Victor. From Ritual to Theatre: The Human Seriousness of Play. New York: PAJ, 1982.

Tyler, Royall. The Algerine Captive; or, The Life and Adventures of Doctor Updike Underhill. Gainesville: Scholars' Facsimiles \& Reprints, 1967.

---. The Contrast, A Comedy in Five Acts. Early American Drama. Early American Drama. Ed. Jeffrey H. Richards. New York: Penguin, 1997. 6-57.

Wald, Priscilla. Constituting Americans: Cultural Anxiety and Narrative Form. Durham: Duke UP, 1995.

Wallace, Anthony F. C. Jefferson and the Indians: The Tragic Fate of the First Americans. Cambridge, MA: Harvard UP, 1999.

Warner, Michael. The Letters of the Republic: Publication and the Public Sphere in EighteenthCentury America. Cambridge, MA: Harvard UP, 1990.

---. "Publics and Counterpublics." Public Culture 14.1 (2002): 49-90.

---. Publics and Counterpublics. New York: Zone Books, 2002. 
Warren, Mercy Otis. The Group. Plays by Early American Women, 1775-1850. Ed. Amelia Howe Kritzer. Ann Arbor: U of Michigan P, 1995. 28-53.

Welter, Barbara. “The Cult of True Womanhood: 1820-1860.” American Quarterly 18.2 (1966): 151-74.

The Weyburn Project. U of Regina, 2002. Web. 15 April 2015.

White, Ed. "Captaine Smith, Colonial Novelist." American Literature: A Journal of Literary History, Criticism, and Bibliography 75.3 (2003): 487-513.

Williams, Anne Patricia. "Description and Tableau in the Eighteenth-Century British Sentimental Novel." Eighteenth-Century Fiction 8.4 (1996): 465-84.

Wilson, Harriet E. Our Nig: or, Sketches from the Life of a Free Black. Ed. Henry Louis Gates, Jr. New York: Vintage, 2011.

Wilson, Katherine. “The Path of a Play Script: Louisa Medina's Nick of the Woods." Cultural Narratives: Textuality and Performance in American Culture before 1900. Notre Dame: U of Notre Dame Press, 2010. 153-74.

Wood, Gordon S. Empire of Liberty: A History of the Early Republic, 1789-1815. New York: Oxford UP, 2009.

Wright, Henry C. "William Wells Brown—His Dramas-Their Power For Good." Liberator 8 Oct. 1858. 163. 